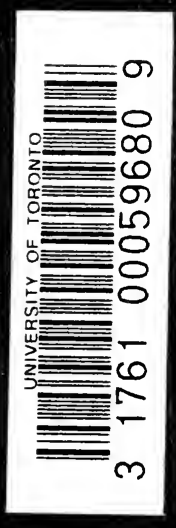


Digitized by the Internet Archive in 2007 with funding from Microsoft Corporation 
<smiles>C=C</smiles> 



\section{SEX AND DREAMS}

THE LANGUAGE OF DREAMS

BY

DR. WILLIAM STEKEL (VIENNA)

Authorized translation by

JAMES S. VAN TESLAAR, M.D.

(For sale only to Members of the Medical Profession)

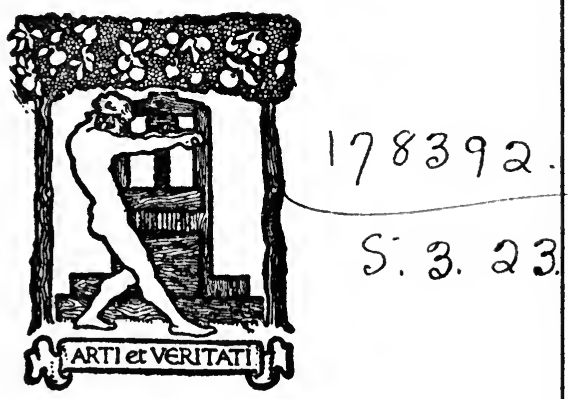

BOSTON

RICHARD G. BADGER

THE GORHAM PRESS 
Copyright, 1922, bx Richard G. Badger

All Rights Reserved

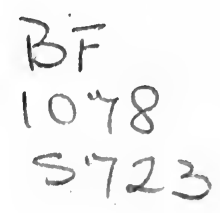

Made in the United States of America

Press of J. J. Little \& Ives Company, New York, U. S. A. 


\section{TRANSLATOR'S PREFACE}

Dr. Wm. Stekel's Language of Dreams, of which the first portion is herewith presented to the English reading professional ranks, is intended as a guide to the interpretation of the Unconscious for those who are concerned professionally with nervous disorders. The balance of the work will appear as soon as the demand for it will make itself felt.

The interpretation of dreams has become an indispensable aid. Without the information it yields regarding the operations of man's Unconscious, the rational management of nervous ills is well-nigh inconceivable. The art of dream interpretation has a wider field of application and elsewhere Dr. Stekel himself has applied the revelations of dream analysis to other fields of scientific inquiry. But the present work, The Language of Dreams, is devoted almost entirely to correlating the subjects' dreams with the neurotic character traits which confront the psychotherapeutist, the general practitioner and the specialist alike, and which often baffle their best efforts in the absence of the kind of knowledge revealed through this very art of dream interpretation. As one of the pioneers in this great work Dr. 
Stekel, of course, is well versed in the theoretical implications and in the theories which form the foundation of dream analysis. Nevertheless in his Language of Dreams he has kept strictly to the practical task of showing "how the analysis is done." The principles of dream interpretation are not discussed abstractly. They are revealed and outlined briefly in connection with typical illustrative dreams. Throughout the work the emphasis is upon practice. Abstract speculation is reduced to a minimum.

Moreover, in preparing this volume, the author appreciated that it must be made serviceable to many practitioners who have had little or no previous training in this kind of work. The contents are carefully graded, the interpretations proceeding from the simpler dream elements to the more complex, and from the superficial to the deeper layers of symbolization. At the same time the author himself warns us that the whole art of dream analysis is but a recent scientific procedure. Numerous details remain to be worked out. The accepted generalizations, he points out, should be regarded in the light of working hypotheses rather than as final principles, and the consulting psychologist should test them out for himself.

The interpretation of dreams is far from being as easy a task as appears at first glance. There are numerous pitfalls for the unwary. Dream analysis is a task that calls for unusual candor and pa- 
tience. To do the work successfully presupposes an immense amount of general knowledge and a broad cultural background. It is an art that involves qualifications of the highest order. Above all, one must be willing to go through a rigorous mental discipline in order to approach the task of dream interpretation without any preconceived bias and without the handicap of subtle emotional resistances.

But after one has schooled himself to the task the results are most gratifying. Properly carried out the analysis of dreams reveals depths of the human soul hitherto unsuspected. It fortifies our professional endeavours with knowledge of the highest order. To adopt the latest scientific methods thus increasing our professional efficiency and enlarging our capacity for serving our fellow-men is a gratifying achievement.

The psychology and technique of dream interpretation, so skilfully presented by Dr. Stekel in the work of which the present volume is the first portion, constitutes a most important method for getting at the vital facts underlying our mental functions during health and disease.

The time has come for the English reading professional ranks to profit by Dr. Stekel's expert application of psychoanalytic principles. Those who desire to penetrate the riddle of dreams as a means towards increasing their knowledge of human nature as it portrays itself reflected in nervous ills should 
8

Translator's Preface

find the present work an invaluable aid. The preparation of the English version has been undertaken with that end in view.

Van Teslaar

August 10, 1922,

Brookline, Mass. 


\section{CONTENTS}

7 I The meaning of symbolism-What is a symbol?The dream about the slain woman-Lovesick humanity-Dream of the jealous father-Dream and myth • . . . . • . . - . •

- II The analysis of a simple dream-The dream about the telephone-The ballad of the poor eagleWhat Mrs. A. thinks of the act of telephoning

III Superficial aspects of dream interpretation-The moon and the earth-The "Rathaus" dreamRepresentation of unbridled life . . . .

- IV Symbolism of the sinking tree-Representation of Mother Earth-The fear of self . . . . .

V Dream masks-Pursuit dreams-The political dream about Bismarck-The wonderful villaThe dream about the baker-Contrary meaning of aboriginal words-The psychology of the Don Juan type-Savings bankbook and love-Evil thoughts of childhood-The skillful fencer-The dark man, a symbol for death . . . . . .

- VI Dream masks, Cont.-Transposition from below, upwards, and from the front, backwards-Scorn under the mask of gentility-A dream which must be interpreted in reverse sense-The second symbolic equation-The symbolization of scornful love-Why the child calls "Papa!"-A biographic dream . . . . . . . . • • . 
CHAPTER

- VII Dream masks-Displacement and fusion-The brave servant-Criminal (asocial) instincts . . 161

- VIII The splitting of personality in the dream-The dream of a judge: villa and prison-The museum dream

- IX Transformations and bisexuality-The meaning of five fingers-An old dream in a new light-Bisexual symbols-All dreams are bisexual-How the dreamer seeks the male in the woman . .

- X Symbolism of left and right in dreams-The cousin as substitute for incest-The father must leave -Symbolism of the spiral-Dream about diplomatic behavior . . . . . . . . . .

- XI The dreams of a doubter-The dream about sweets-The dream about stolen books-The second version . . . . . . . . . . . .

- XII The symbolism of life and death in the dreamThe long sharp sword in the dream-Masturbation represented by pocket-The matricide idea -Blood for spermatic fluid . . . . . .

- XIII Speech in dreams-The symbolism of conversation -Color symbolism of Mr. S. . . . . . . 271

XIV Representation of the emotions in the dream-The dream of "getting ready"-A clergyman's dream -The root of foot fetichism-Triumph over the father-Dream thoughts and compulsive images -Infantile roots of the fear of contact-Why the dreamer "wonders" . . . . . . . . 281

Index of Subjects . . . . . . . . . 315

Index of Names . . . . . . . . . . . 318

Index of Symbols . . . . . . . . . 319 


\section{AUTHOR'S PREFACE}

Every mental activity is dominated by the law of "bipolarity": to every instinct there corresponds a counter-instinct; to every virtue, a vice; to every manifestation of strength, some weakness. One can never understand the nature of man so long as one fails to take into consideration this fact.

My work treats of the secrets of the human soul. It would be unfair to appraise humanity on the basis of the results of these investigations. For this work deals specifically with the evil in human nature, and only with the evil. But we must not forget that there is also another side.

Perhaps I can make myself clear best through an example: A stranger comes into some town unfamiliar to him; he looks over very thoroughly and with great enthusiasm its monuments of art; he is charmed by" the beautiful sights which culture has provided. He then departs believing he has become thoroughly acquainted with the town. Another traveller says to himself,-after having gone through the program suggested by the usual traveller's guide: Now I want to look into the reverse side 
of the life of this place! He knows that the pompous formal life has its seamy side, and he discovers once more that only he is able truly to appraise the light side of the picture who has familiarized himself also with its shadows.

My investigations are concerned with the foundations of the human soul. They are not intended for inexperienced lay persons whose minds may be confused rather than enlightened by these investigations. Physicians, jurists, mental hygienists, educators and psychologists will undoubtedly find herein a certain amount of inspiration and their mental horizon will be enlarged. It is high time that we devote greater attention to the facts of our dream life. This field opens to us the opportunity of acquiring insight into the very depths of the human soul and thus enables us, for the first time, to penetrate the true character of human nature.

In the conception of this book, the result of many years of diligent labour, I have been guided primarily by practical requirements. The theoretical aspects and the past literature concerning dreams have been covered so well by Freud that I must refer all those interested to that author's fundamental and highly instructive work.

My work should not be merely read,-it must be tested out. I welcome every criticism so long as it is not dictated by blind prejudice, for the person 
unfamiliar with the problem of dream interpretation will be inclined to look upon some of the statements in the book as somewhat forced and perhaps artificial.

This was my own experience, when I first began to devote myself to the subject of dreams. Conviction cannot arise through reading alone; it follows only after personally testing out the principles.

I may point out, additionally, one fact: the interpretation of dreams is a science in the process of formation. Everything about it is in a state of flux, everything is in the process of becoming formulated. This book is but a rung in the ladder. Who can at this time measure the majestic heights eventually to be attained by the structure to which the present work is but a stepping stone?

STEKel. 

THE MEANING OF THE SYMBOLISM-WHAT IS A SYMBOL?-THE DREAM ABOUT THE SLAIN WOMAN -LOVESICK HUMANITY-DREAM OF THE JEALOUS FATHER-DREAM AND MYTH 
Wahrlich, roären die Menschen sinniger, die feinen Winken der Natur zu beobachten und zu deuten, dieses Traumleben müsste sie aufmerksam machen. Sie müssten finden, dass von dem grossen Rätsel, nach dessen Lösung sie dürsten, die Natur uns hier schon die erste Sible eingeflïstert hat.

[Truly, if men were more sensitive to observe and interpret nature's delicate hints, they would be roused by their dream life. They would find that here nature has already disclosed the first hint of the great riddle which man is so thirsty to solve.]

Kürnburger 


\section{SEX AND DREAMS}

I

The art of dream interpretation is a most ancient one. Some of the oldest documents relate to dream interpretations. The dream was considered an intermediary between the higher forces of nature and mankind. Usually it was the voice of divinity that was speaking through the medium of dreams. But demons and evil powers, too, were capable of coming into contact with man through the dream life. That was a period which we, belonging to a sophisticated age, can hardly visualize. "The lights and shadows and the coloring, at any rate, have changed," says Nietzsche. "We no longer understand precisely how ancient mankind felt about the most ordinary and common facts of life-about daylight and about waking up; for instance: because the ancients believed in dreams, their roaking life had another coloring."

Contrary to the learned men, the simple folk have never looked upon dreams as "foam." Within their soul there persisted a belief in the reality of this 
psychic experience. But the belief rested stubbornly on what might be termed the "historic" background: the people wanted to interpret the future through the dream. The dream was looked upon as the infallible prophet. Whoever could interpret dreams possessed the gift to solve the riddle of the future. A derivation of this belief is the application of the dream to mercenary ends. The transposition of the dream pictures into figures is diligently practiced to this day and plays a great rôle among the people. ${ }^{1}$ The "cultured" classes regard it as their duty superiorily to smile at such practices. They look upon the dream as a meaningless play of the phantasy uncontrolled by consciousness. Even so, ordinary reflection should have suggested the thought that here was raw material of great psychic value, though in a distorted form. We ought to see what we can make out of it. Here and there an investigator occasionally tried to penetrate the riddle of dreams. But these promising beginnings only led to far-fetched theories. ${ }^{2}$

1 I want to take this opportunity to state that I have not disdained to look over the various Egyptian and Persian dream books. I wanted to find out whether our knowledge derived through the modern analysis of dreams is in any way corroborated in the old writings. That is but rarely the case. The dream books, so-called, which circulate among the people, impress me as being deliberate artefacts. The transposition of dream pictures into numbers is clearly traceable to the lottery game which is only a few centuries old.

The extensive literature on dreams has been adequately considered by Freud to whose work the interested reader is referred. 
Anatole France is justified when he states: "I am firmly convinced that the power of dreams is greater than that of reality." The dream is the bridge between the real and the supersensory world. The ancient peoples knew this better than we. They believed in dreams and through the dream they felt themselves nearer their divinity.

Divinity is the projection of our ideal into infinity. What we demand of our ideal self appears to us as God's command. All appearances of self are continually referred to an ideal that stands supreme. Hence the first conception about the origins of dreams, - that the dream is a gift sent down by the gods. The divine voice commands and warns, it annunciates and praises through the dream. The dream interpreter of former ages claimed the gift of understanding that secret language and to be able thereby to foretell the future.

But not only is the ideal self projected into infinity. The evil self is also refracted outwardly and it reflects back as temptation or as the influence of demonic powers. The naïve conception of the middle ages was that the dream represents a struggle between heaven and hell, a contest between God and Satan. That combat has always fascinated man's fancy. From Job and Jesus down to Faust and Parsifal,-what a wealth of poetic creations!

It is the eternal warfare between instinct and repression, between man, in his primordial character, 
and himself, under the tinsel of culture, which breaks forth in this wonderful symbolic picture. Our culture requires the continual repression of our cravings. The higher man ascends upon the cultural scale the stricter are the laws which impose the ethical strictures of the society in which he finds himself. Culture means smooth-working inhibition. The greater the social freedom, i.e., the stronger the social rights of the individual, the smaller becomes the span of his individual freedom; the stricter also the limitations which the individual must impose upon himself for the benefit of all. Social progress is based on the annihilation of individualism.

The dream represents an indulgence in fancies without the intervention of consciousness or under a limited control by the latter. The dream is a hallucination. Consciousness is the bearer of inhibitions. The ethical self first assumes control of consciousness and then it attempts to penetrate into the depths of the unconscious. Hence the cleft which arises between the pictures of the waking self and the hallucinations of the dream. Conscience is the sum of all inhibitions of a religious and ethical character. The term conscience in itself shows that it pertains to a knowledge of good and evil. The primitive man has so such knowledge. He is familiar only with the promptings of his cravings; with unpleasure, which arises out of the non-fulfillment of wishes and with the pleasure which accompanies and 
follows their gratification. The primordial man in us lives again in the dream.

But the tremendous gap which exists between the requisites of our cultural and those of our elemental self leads eventually to a strange state of affairs. The cultural self knows not, or assumes not to know, the primordial self. It fails to recognize the language of the dream and thus carries out more completely its attitude of "innocent" ignorance. For that reason, too, the dream portrays its images in a secret symbolic language. Its language is the language of the primordial man. For man's aboriginal ancestor also expressed himself in symbolic form. The earliest written documents are symbolic writings. A sword signifies fight, a tree nature, lightning divinity, etc. The art of dream interpretation consists of transposing this symbolic language into everyday terms.

What is the function of the dream? We pass over the old conception according to which the dream was merely a senseless play of mental elements; we disregard likewise the ancient hypotheses which were based on the premise of an intervention of evil powers. We turn directly to the theory of Freud, who regards the dream as a wish fulfillment.

"Our relations to the world," states Freud in his latest writing on dreams, "is from the outset such

${ }^{2}$ Vorlesungen über Psychoanalyse (Wien, 1920). 
that we cannot endure it without a break. Therefore we withdraw from time to time into the primordial state,- - that state which is characteristic of our intra-uterine existence. At least we create for ourselves an environment very close to it: warmth, darkness, and absence of stimuli. Some of us curl up and actually assume during sleep a position very close to that which is characteristic of the infant when resting within the mother-body. It looks as if the world does not possess us wholly as adults, it can lay claim only to two thirds of us: for one third of our existence we are as if we were yet unborn. Every rising in the morning is thus like a new birth."

Hebbel has expressed the same thought more fittingly without recourse to the dubious notion of a sinking back into the intra-uterine state: "Sleep is a sinking into one's self." I have expressed the same idea in my monograph, The Will to Sleep, as follows: "Sleep means reëxperiencing one's past, forgetting one's present, and pre-feeling one's future."

This one example from Freud's latest work is enough to show the one-sided character of his conception of dreams. The dream is and remains for him a wish fulfillment. Into this procrustean bed of wish he wedges in every dream. Thus he neglects altogether the telepathic dreams which do not happen to fit in with his theory. He does not believe in telepathic dreams. But he brushes aside also 
all other dreams, which we must recognize as denoting warning or anxiety as well as the dreams which we may call "instructive." Anxiety is always for him the sign of a repressed wish. But knowing that the dream portrays the eternal warfare between craving and inhibition, the struggle of man with himself under his dual aspect as the heir of primordial instincts and as the representative of culture, we must look upon the dream as a picture of both sides of the combat, a dramatization in which the cravings as well as the inhibitions find pictorial representation, and in which even foreign thoughts may crop out through telepathic means. If one sees only the cravings, one may be easily led to the erroneous conception which I myself have held for a time, that the dream is merely a wish fulfillment. For back of every wish there always stands some craving: the sexual instinct, the nutritional instinct, the craving for power, for self-aggrandizement, etc. But if we investigate the inhibitions we find back of them also the influences of culture: warnings, preparation for the future, foreshawdoings, religiosity and moral restrictions of every kind.

Perhaps my conception will be more clear if $I$ contrast it with Freud's in connection with a concrete illustration. In the work mentioned above Freud relates a peculiar dream and adds his interpretation. He states: 
"One of my patients had lost her father during the treatment. Since then she takes every opportunity to find him again in her dreams. In one of her dreams the father appears in a certain connection .... and says: 'It is a quarter past eleven, half past eleven, it is a quarter of twelve.' Towards the solution of this strange dream feature the patient recalls merely that the father always wanted to see the children gather for their meals on time. That undoubtedly had something to do with the dream element in question but this association yields no light on its meaning. On account of certain considerations which arose in the course of the treatment the suspicion seemed justified at the time that a carefully repressed, critical revulsion àgainst the beloved and honored father had its share in this dream. Continuing further her associations, apparently in a direction remote from the dream proper, the subject relates that she had listened the day before to a lengthy psychologic discussion when a relative said: 'The primordial man lives in each of us!' We now think we understand her. That gave her an excellent chance to conjure into life once more her deceased father. She made him in the dream the primordial man, by having him call out the quarter hours for the noon meal. (UrmenschUhrmensch, a play on words!)"

Any one finding this play of words between $U h r-$ mensch, clock man, and Urmensch, primordial man, rather forced, will be informed by the genial master that the dream is capable of punning and wit. The dreamer wishes to see her father, and the obliging 
dream fulfills her wish. Therefore, a typical clear wish fulfillment,-according to Freud. I would have conceived this dream as a warning. The death of her father had strongly influenced the patient and caused her thoughts to shift from worldly to supermundane themes. She is interested in the question of life after death. This earthly life must be but a preparation for the life eternal. It is as if the father cried out to her: "Life is short! Use your days well! Soon twelve bells will strike (the ghost hour). Soon your day will be over!"

The flight of time is very ingeniously indicated by the progressive admonition: "a quarter past eleven, half past eleven, a quarter of twelve." Since the neurosis expresses the struggle between craving and repression under the form of an ailment, we may appreciate the patient's trouble. A power draws her towards indulgence and enjoyment and another pulls her in the direction of renunciation and selfcontrol. The father appears as the representative of authority (also of the divine) and admonishes her: "Renounce all earthly joys and prepare thyself for God's judgment, for the life eternal. The day of judgment is near."

But is this dream a wish fulfillment? If the father appeared in response to her wish, conjured up (hallucinatorily) by her yearning to see him again, would he have found no other words, no kindlier attitude, with which to approach his child? 
I see in this dream merely the power of conscience. I sense the torturing anxiety, I note the racking regret over a life misspent or lost, I hear an anguishing outcry which fills me with compassion.

This dream is a warning and it foreshadows at the same time the subject's future. She will continue to wander on the path of asceticism and self-denial. Letters of flame proclaim in the subject's dream the approach of that end which overtakes every one. And,-what about the character of the dream? It is wish or a warning, according to the power (craving or inhibition) which pervades it. The dream seeks solutions for unsolvable problems. It is an apposition of past and present and a foreshadowing of the future. Its realm is inexhaustible and it is not to be encased within the narrow limits of a formula. The dream is in fact as inexhaustible as the riddle of man and yet as transparent as man, provided one does not start out with any preconceived notions. Are the thoughts of a person in the waking state reducible to a single formula? Do we think merely in terms of wish fulfillment? This question is rendered superfluous when we take into consideration the factor of conscience alone. The dream is the stream of our mental life as it flows out of the unexplored depths through the filter of conscience and up to the level of awareness.

Every falling asleep is a dying for the day. Every waking up is a rebirth. The thought of death re- 
veals itself in curious pictures in the dreams. Though we forget the fact of death during the day, and though the bustle of daily existence may stifle the voice of conscience, the dream brings back to our mind the eternal "memento mori!" Each one of us hears the admonishing voice: "It is a quarter of twelve!" And we hear it in the midst of our entangling wishes,-we hear the swan song in the midst of all the frivolous cravings. And thus we die many times, and we pass again and again through the last accounting,-thus we look over our past critically, appraisingly, amidst fears and regrets. Every night provides a cleansing purgatory for our world of thoughts. Within us lies heaven and earth,-within us judge and defendant alike. It is as if the ideal which we have shifted to infinity at night finds the path back to us again, as if we are trying every night to overcome once more the demons which incite us from one indulgence to another and which fill our childish heart with envy and with feelings of revenge, with treacherous selfseeking and forbidden cravings. And every dream dramatizes plastically this bitter combat, every dream is a proof that humanity strives to grow out of itself and up towards unsuspected heights. In Grillparzer's ${ }^{1}$ wonderful drama, Traum ein Leben,

${ }^{1} \mathrm{Vid}$. Analysis of this drama in my: Poetry and Neurosis, Contributions to the Psychology of the Artist and of Creative Activity. English version by Dr. James S. Van Teslaar. 
we find a wonderful expression of this function of the dream as a warning, as a picture of the struggle between craving and inhibition. The artist has furnished us in this poetic drama the key to the understanding of dreams.

But we must be grateful to Freud for having shown us the path leading into the realm of dreams and for having been the first to penetrate with the pioneer's keen eye the veil which has kept the dream a secret. To-day the interpretation of dreams has become an indispensable aid in the practice of psychotherapy. Any one intending to be helpful as a psychotherapeutist must familiarize himself with the art of dream interpretation.

It is not an easy art to acquire. It requires special training and a great deal of patience. It involves careful testing for one's self of the results thus far gained until one acquires the requisite knowledge and conviction through personal observation and experience.

The proper schooling for the interpretation of dreams involves an appropriate new conception of language, the keen tracing of double meanings and familiarity with symbolisms and with the processes of dream distortion.

The rôle of symbolism in human life is not yet sufficiently appreciated. "All art is symbolism," states Feuchtersleben. "The most important task of my career," states Hebbel, speaking as an artist, 
"I regard the symbolization of my inner life." Symbolism pervades all our existence. Language, customs, beliefs and thoughts are more or less cryptic symbolisms.

Without knowledge of symbolism the interpretation of dreams is an impossible task.

The proper training for dream interpretation consists of learning to read aright its language, of tracing the double meanings and of becoming familiar with the symbolisms and processes of dream distortion.

The significance of symbolism in human life is still but insufficiently recognized. "All art is but symbolism," states Feuchtersleben. "The most important task of my life," declares Hebbel, "I regard the symbolization of my inner life." Symbolism pervades all our life. Language, customs, peculiarities, thought, - all are more or less hidden symbolisms. To Rudolf Kleinpaul belongs the credit of having shown up the tremendous significance of symbolism, through his various works, particularly, his Sprache ohne Worte (Language without Words) and his more elaborate work entitled, Das Leben der Sprache (Leipzig, Wm. Friedrich, 1888).

What is truly a symbol?

Riklin states: ${ }^{3}$

Schriften zur angewandten Seelenkunde, II Franz Deutike (Wien u. Leipzig, 1909). 
"A symbol is a sign, an abbreviation for something more elaborate. When I look over a railroad time table and find a 'postal sign' in the form of the familiar horn mark, against the name of a station, it enables me to know that the station has postal connections with places not on that line.

"But the symbol stands for more than that. Why does not some other sign stand for postal connections in the railroad time guide? The postal horn is something that originally belonged to the postal service. Although no longer an essential part of that service it was formerly one of its most conspicuous signs, impressive both to the eye and to the ear. Thus we find here two additional features which belong to the symbol. The sign chosen for a symbol stands in associative inner, as well as outer, relationship to the thing it signifies and is meaningful. It is particularly fitting as a symbol on account of its history and development in connection with the thing it signifies, although its importance in that connection is not without its fluctuations. At the present time we no longer have the long-distance drivers lustily blowing their horn. But the horn persists as a sign in the railroad time guides, in military service denoting the field postal station, and in various other connections.

"Usually the concept symbol embodies also something mystical (or mysterious). Symbols are frequently used as signs of recognition among members of secret organizations, as for instance, the signs among the Freemasons. The 'mysterious' feature consists of the fact that only the initiated is familiar with the meaning of the sign. That was the case, for instance, with the Runic Characters, 
which only certain persons could read; that, too, is what lends churchly ceremonials their power of impressing the human sensitive mind. Developmental history and the changes in meaning incidental thereto are enough to obscure the true meaning of the symbol to all but the initiated.

"Because the symbol is only a sign, only a part of the original thing which it stands for, in the course of its developmental history it may gradually assume varied significance and stand for a number of things: the postal horn may be variously taken, in a psychologic sense, and may mean any one of a number of things according to the locality, or circumstances: it may mean 'junction' when placed against the station name in a railroad time guide, or 'postal connection' when found in a circular. In a distant mountain village it means one thing, on a uniform sleeve it stands for something else.

"This indication of possible meanings shows that the sign or symbol stands for a summation or fusion of all the possible associations. It is characteristic of the dream symbol, for instance, that it takes in thousands of association paths. This leads to many-sidedness and the 'shadowy sense' of the symbol lends itself, for that reason, to a number of plausible interpretations. Any one who is not experienced and does not know the symbol in all its possible applications, may interpret it falsely or only in a sense with which he happens to be familiar. The Bible, for instance, has the advantageand disadvantage at the same time,-of containing numerous symbols which may be interpreted in any one of various ways." (Wunscherfüllung und Symbolik im Märchen.) 
Without a knowledge of symbolism the interpretation of dreams is impossible. The great fault of modern dream interpreters was precisely the fact that they knew nothing about symbolism. The ancients were further advanced in that respect. How impressive is the symbolism of dreams set forth in the Bible! And how completely rounded out appears the symbolism of Artemidoros of Daldis, whose book entitled The Symbolism of Dreams is worthy of the modern psychoanalyst's attention. ${ }^{4}$

Before beginning to describe the art of dream interpretation proper let us turn our attention briefly to the Bible dreams and to the Greek art of interpretation. I know no more fitting examples for introducing the subject of dream symbolism.

The best known is the dream interpretation of Joseph, found in the first book of Moses. Joseph owed his high position entirely to his extraordinary ability to interpret properly his master's dreams. The first dream which he told his brothers, was:

(1) We tied sheafs on the field and my sheaf stood upright; and your sheafs bowed before my sheaf.

The brothers at once interpreted the dream to mean that Joseph will surpass them: "Shalt thou be our king and rule over us?" Even we children of this age could not interpret the dream otherwise.

-There is an excellent German translation of this work by Friedr. S. Krauss (Hartleben, Vienna, 1881). Unfortunately, the most significant portion, The Symbolism of the Sexual Processes, has been omitted. 
Only we are able to conclude from it that it is the dream of an ambitious person. And since ambition carries one far, especially when one is endowed with the necessary wisdom and with indefatigable energy, we are justified to surmise favorable augury regarding the future of any one whose youth is filled with such dreams. ${ }^{5}$

The second of Joseph's dreams also denotes similar ambition:

(2) I thought the sun and the moon and the eleven stars bowed before me.

This dream led to his supposed perdition and was the beginning of his miraculous good luck. Equally remarkable are Joseph's further interpretations of dreams:

(3) The seven ugly starved cores, which eat up the seven fat cows

he genially interpreted as seven years of famine which were to follow seven years of abundance.

These interpretations exhibit a remarkable grasp of dream symbolism.

The art of dream interpretation was similarly developed among the Greeks, and I quote two examples from Artemidoros (loc. cit., p. 236):

(4) Some one dreamed of being tied with a chain

"In modern dreams "ambition" is symbolized by modern means: the ambitious person flies high above the heads of all others in a balloon, aeroplane, or according to the good old fashion, as an angel. Sometimes the flight through air is carried on without wings, merely by swaying the limbs or the body. 
to the post of Poseidon. He became a priest of Poseidon; for in that position he could not get arway from the holy place.

This glimpse into the future is as clever as the next prophecy of Artemidoros which I shall presently relate. No one becomes a priest who did not first wish it, unless he were coerced. . . .

The second dream from the work of Artemidoros shows a symbolism to which we will have occasion frequently to revert. In that dream picture the sexual is represented as flesh: the sensuous in man, through the flesh of an animal.

(5) Some one dreamed of seducing and sacrificing his own wife, of bartering with and offering her flesh for sale, and that he earned a great sum thereby. Thereupon he dreamed that he was. very joyful over it and he attempted to hide the money he had gained, on account of the jealousy of those around.

"That man eventually sold his own wife and made money out of the shameful deed. That source of income proved very profitable but he found it necessary to keep the matter from any one's knowledge."

In the case of that man, too, wish was father to the thought, - and that, long before the deed. He first dreamed what he lacked the courage of carrying out. As he could look upon the dream as an order from the Gods, that dream led to a course of action which he might have adopted even in the absence of the dream. Possibly only in a short time. 
The dream is a dream of impatience. The dreamer can hardly wait to sell his wife and acquire the gain.

From the art of dream interpretation of the East one might also draw some excellent examples. I limit myself to one account of a jest of Buadem (literally "that man"), a name which, according to Dr. Muillendorf, is only a pseudonym devised by Mehemed Terofik, the publisher, for the well known JesterPoet, Nassr-ed-din. This Turkish Eulenspiegel is supposed to have "flourished" during the fourteenth century.

Buadem was not quite five or six years of age, when he related the following dream to his father:

(6) "Father, last night I have seen fancy cakes in my dream."

"My son, that has a good meaning." (Jokingly:) "Give me ten paras (the smallest monetary unit current in Constantinople) and $I$ will interpret the dream for you."

"If I had ten paras, I would not be dreaming of cakes." 6

Let us now take a long jump all the way into the sixteenth century and turn our attention to a dream of the famous physician, philosopher and mathematician, Cardanus, author of a book, $D e$ Somniis, and whose faith in the prophetic truth of

- Die Schwanke des Nassr-ed-din und Buadem. Reklam Bibliothek, 2735. 
his dreams was so unshakable that he chose his wife, the daughter of a highway robber, after a resemblance with a face he had seen in dreams; the dream had prophesied for him the awakening of his passion, previously dormant, in that particular woman's company. He had been impotent up to his thirtyfourth year. That an impotent man should crave entrance into the "garden of love" any one may easily understand. Here is how Cardanus relates the story:

(7) One night I found myself in a beautiful garden of flowers and fruit. A soft air pervaded everything so that no painter, no poet, no human thought could have conjured up anything more charming. $I$ was at the entrance to that garden. The gate roas open and I sare a girl clad in white. I embraced and kissed her; but at the very first kiss the gardener bolted the gate close. I begged him most fervently to leave the gate open. It seemed to me that I felt sad about it and I was still clinging to the girl when $I$ was locked out.

What is a man of rich imagery likely to dream about when the garden of love closes on him? This beautiful example shows us the day wish in a symbolism but partly covered up. But the symbolism is not always so obvious and plain as in this example. Often the whole dream is devoted to a symbolic dramatization. I want to avoid for the pres- 
ent the more complicated problems which we shall have to consider later. I shall merely quote an example from Freud's Interpretation of Dreams showing how the dream expresses colloquialisms through pictures.

A lady dreams:

(8) A servant girl climbs on the ladder, as if preparing for window cleaning and carries a chimpanzee and a gorilla cat (later corrected to angora cat) with her. She throwes the animals at the dreamer; the chimpanzee clings to the latter, who finds this very disagreeable.

"This dream has achieved its end through the simplest of means, namely, by taking a colloquialism literally and representing the picture to which it gives rise. 'Monkey,' like almost any animal name, is a derogatory term, and the dream situation merely depicts the colloquialism 'mit Schimpfworten um sich werfen,' 'hurling insult'." (Freud, Interpretation of Dreams, translated by Brill.)

Occasionally we are compelled thus to reduce the situations and pictures of a dream back to Redereendungen, "colloquialisms." The dream takes words in a literal sense; we must conceive the processes pictorially. That requires a special art and particular practice. Both must be acquired.

In order to illustrate what $I$ have just stated I record now a brief dream with a very significant 
content. Beta, ${ }^{7}$ a man suffering of anxiety has the following dream:

(9) I see before me a large rooden picture of the Christ. I take a chip out of it.

This dream is also to be understood in a symbolic sense. The dreamer is still a believer at heart, even strongly so, though outwardly a fanatic free thinker. The day before the dream he had read a book, entitled La Folie de Jésus (The Insanity of Jesus). ${ }^{8}$ Suddenly he had to give up the reading. $\mathrm{He}$ is unable to state why. It was a compulsivelike act. Like a commandment: Nore, quit reading! The deeper reasons for this compulsion-like act are revealed in this dream. Er hat sich etwas gegen seine Gottheit herausgenommen (a German colloquialism not unlike our "chip on the shoulder" expression).

The further significance of this dream and the relationship between anxiety and wish need not be taken up at this time. For the present $I$ have merely attempted to indicate in a few general lines the foundations of dream symbolism. The understanding of symbolism forms the basis of dream interpretation. We have had even before Freud some

For the subjects whose dreams are repeatedly quoted I have adopted substitutive designations in the form of Greek letters. The names of all persons are changed so as to make their recognition impossible. That is a strong disadvantage in a work of this character. But it cannot be done otherwise. Discretion is the first duty of the psychotherapeutist.

${ }^{8}$ Dr. Binet-Sanglé, La Folie de Jésus (Paris, Maloine, 1908). 
intimation of the rôle of symbolism in human life. Schubert and Kleinpaul, for instance, have dwelt on the symbolic conception of life as a whole. These investigators have also boldly pointed out the sexual symbolism. Is it not remarkable that our language (the author here refers, naturally, to the German) distinguishes words according to their gender?

When we take up the dream analysis we are impressed with the far-reaching extent of our symbolic thinking and particularly of sexual symbolism. In the dream anything oblong may represent the penis and anything round many stand for the vagina. But is that the case only in dreams? One should consult what Kleinpaul has to say on the subject in his work entitled Das Leben der Sprache, already mentioned, particularly in the chapter on Die Psychopathia Sexualis des Volkes (loc. cit., vol ii, p. 490). He points out that language as a whole is sexualized and symbolized. Language is full of sexual symbols.

"Indeed, the human race is love-mad," say Kleinpaul. "Whichever way we turn we meet perpetually her phantasy, half morbidly, half foolishly centered on the sexual sphere. The race seems to have lost its reason! It cannot put the male and female out of its mind, it cannot see an elevation or a hole without thinking of sex-and if it is a tower in which prisoners are languishing away, it is called il maschio di Volterra.

“The iris is called 'das Mädchen des Auges,' lit- 
erally, the 'girl of the eye', not because of any resemblance to a girl. The iris itself is a girl. Because it has a hole in the middle-no anatomy is needed for that - the black mid-spot in the middle of the eye looks like a hole. Hole, trypa, $\tau \rho \tilde{v} \pi a$, trou, in all languages is the name for woman, so also in Genesis (i. 27); and because the eye is small, it was regarded as a little girl.

"Reflection or thought assumes this erotic bent particularly when something fits into a hole, like the foot into the shoe, or the knife into the sheath,when things come in pairs and one sticks into the other. All such 'paired' things evoke the 'great luck' of sexual beings, sexual union,-that which is called lingam in the Ganges region.

"'Qual Buco, tal Cavicchio,' is an Italian proverb, or, as Fischart once remarked, 'es war eben ein Zapf für diese Flasche, denn faule Eier und stinkende Butter gehören zusammen,'- 'the right stopper for the bottle, for bad eggs and rancid butter belong together'; a popular German saying expresses the same thought: "Auf jedes Töpfchen gehört sein Deckelchen,'-'every vessel has its cover.' Es ist eben recht dahinterher," continues Kleinpaul, "and numberless technical expressions can be explained only through their reverberation of the old Adam and Eve theme. The numerous mothers, matrices, etc., in the various technical industries have the same origin.

"Mutter, Nonne, Weib and Schnecke, mother, nun, female, screw; on the oiher side Vater, Mönch and Mann, father, monk and male, represent here only the important parts. There is deep significance in such terms: monk and nun. Often it happens the 
male half bears also a particularly significant name, like stamp, or spindle, while the typically female parts are poetically covered up. The screw seems to imply a marital relationship (spindle and female)."

Truly, Kleinpaul's statement is correct: Language is full of sexual symbols.

In fact, it is enough to perceive the true spirit of the language in order to interpret quite a number of dreams. A young boy, sixteen years of age, whose father is a famous artist and a very popular Don Juan much admired by the ladies, tells me the following dream:

(10) Father finds various holes in the rooms. I am worried because he alone wants to stop them up.

When I ask him why it worried him, he answered, "Because father took all that trouble alone. I could help him. That is not a suitable task for so great an artist." He rationalizes his dream-to use the fitting expression of Jones. But we prefer to take the dream literally. The young man is an Alexander who is worried because Philip leaves him nothing to conquer. All the women in the house worship the father: the mother, the aunt, the French teacher, the secretary. He suspects the father of relations grossly sexual-perhaps justifiedly. The holes in the walls are to be taken in Kleinpaul's literal sense.

We began with the general neutral symbolisms- 
the sheafs in the field ${ }^{9}$ and already we find ourselves in the midst of erotic symbolism. That is inevitable in the case of dream interpretation. Whoever takes up the subject must be prepared to meet the issue.

I may mention here another forerunner of Freud's, - the well-known investigator of dreams, Scherner, ${ }^{10}$ who has conceived the hypothesis that all dreams are generated by bodily sensations. That theory has proven altogether untenable. Nevertheless its founder formulated a fairly correct view of sexual symbolism. Some details may appear ridiculous. But facts lose none of their significance merely because they seem ridiculous.

Regarding sexual symbolism Scherner writes:

"Sexual excitation is symbolized by representations of the erect organ itself or by pictures and phantasy actions which aroused desire for sexual gratification. But here, too, we meet the masked formulations as preserved by the plastic art of the phantasy. For instance, one finds on the street while on the way to a particular spot, the stem of a clarinet, near by, the similar portion of a pipe, a penny whistle, or a piece of fur. (The stem of clarinet or whistle represents unmistakably the form of the male organ, the stem-like configuration of the found object corresponding to the similar form of

- Joseph's dream may also lend itself to another,-an erotic interpretation. Dreams of "greatness" and the wish for extraordinary potence often go hand in hand. Paranoiacs with delusions of grandeur often claim they have a thousand wives, a thousand sons, etc.

${ }^{10}$ Das Leben des Traumes (Berlin, Heinrich Schindler, 1861). 
the external male sexual organ; but the found objects are always double, on account of the character of the excitation of the double organ of vision, which is primarily involved in the act of finding the respective objects. Finally the fur piece in question stands for the pubic hairs, just as the brush stands for eyebrows and eyelashes, instead of the symbolically more fitting bush; finding the three pictures together means the conjunction of the objects represented through them.) $\mathrm{Or}$ as the result of bladder stimuli one finds a curiously crumpled up short stem or cigarette holder which portrays the collapse of the whole male external apparatus. More clearly delineated appears to be the symbolism denoting states of sexual tension, such as usually follow urinary stimuli, the clearer symbolic expression corresponding to the sharper degree of stimulation. For instance, one sees through a clump of trees under which one is standing a near-by tower of great height, and one wonders that the highest peak of the familiar tower (an object known in reality) is crumpled up, and observing the round cupola below, the impression is gained that a second peak (nothing corresponding to reality) must have flattened out down there; while thus watching attentively, the dreamer sees himself standing under women, or he sees them step over him. The high tower represents the tension of the active organ, its peak seems crumpled or flattened, corresponding to the uppermost portion of the sexual apparatus; phantasy seeks forcefully to find two towers where only one exists in reality, in order thus to express the parity of the lower organ; it suggests the vision of a high tower through the undergrowth, because 
the active organ in erection stands forth in the midst of the surrounding pubic hair (underbrush). Tower, peak, double ball, cupola, underbrush, together express a composite thought, because phantasy fuses all pictures in one. . . (Das Leben des Traumes, p. 197.)

The next dream is that of an unmarried thirtyyear-old woman:

(11) Papa goes around cutting off all the leaf ends to all the plastic figures in the room. I amd angry at that and want to prevent it. I am thinking: has he turned crazy?

The girl tells us that her father was always terribly jealous. He did not allow her so much as to shake hands with a strange man. Young men never called at the house. She could not attend a dance. That is how she remained unmarried.

This dream we may also take in a literal sense. The father removes all ends, he thus prevents her from having an opportunity to become familiar with a phallus. In the dream she finds courage to tell him what she, unfortunately, has never dared say to him in actual life. She was the obedient type of daughter. There comes to her mind a figure protected in front with the usual fig leaf. We note the circumlocution so characteristic of dream thoughts. Why that covering? What was the fig leaf for, if the ends are clipped off? She notes how senseless 
her father's conduct seemed to be. She is struck by the peculiar (crazy) feature of his conduct.

We thus perceive in connection with two different dreams the meaning of "hole" and of "end" or peak. The language of dreams makes use of the cryptic forces which have created our everyday language.

That symbolism holds true not only of dreams. It is equally valid in connection with stories, myths, folklore and wit.

The symbolism of fairy stories is particularly clear.

Dream and story! What wonderful association! What the children experience, the adults dream about. New principles are being evolved. We transpose the old truths and now declare: the obverse is true: what the adults experience, the children dream about. That is not a mere play on words.

Freud has furnished us the key to the meaning of dreams. Dr. Franz Riklin tries to apply that key to the investigation of the charming realm of fairy stories. And lo! the attempt proves successful. It turns out that the fairy stories of children bear an intimate inner relationship to the dreams of adults, that they are pervaded through and through with a cryptic sexual symbolism the significance of which presents no particular difficulty. The Wunscherfüllung und Symbolik im Märchen (Wish Fulfilment 
and Symbolism of the Fairy Story) by Riklin, proves that the fairy story has a cryptic sexual meaning. The fairy story, too, represents a "wish fulfillment" in Freud's sense, like the dream.

The simple fairy stories represent relatively simple folk wishes. Riklin brings a number of excellent illustrations. Who is not familiar with the charming Märlein in Bechstein's famous collection of fairy stories? A mother weeps three days and three nights over her most deeply beloved child. At night the door opens softly and the deceased child appears in its nightgown carrying the little tear vessel in which all the mother's tears are gathered up. A few more tears and the little vessel is filled to overflowing and the child attains peace and quiet. "Therefore, weep no more, for thy child is well taken care of and little angels are its playmates!" The child disappears. The mother avoids shedding more tears. The child must not be disturbed in its heavenly peace! Riklin very properly observes that the story could equally well be an actual dream of some particular person. But it happens not to be an account of a particular experience; this curative means (consolation) has become a generalized, psychically purposive belief,-namely, that excessive tears disturb the peace of those who have passed away! That is not a notion helpful to the dead but it is helpful to the living. The same motive is played up in numerous variants: in the Japanese story 
about the "Nun of the Temple of Armida"; in another German version by Grimm as "Todtenhemdchen"; in the "New Islandic Folktales"; edited by Ritterhaus. Everywhere the wish of the adults to be rid of their worry sooner reveals itself as the cryptic motive of the weaver of the fairy story.

The sexual symbolism reveals to us the character of the story even more penetratingly than the principle of wish fulfillment. Here we first learn that the adults tell the child chiefly what they themselves prefer to hear. Naturally they do so in symbolic, that is, masked, form.

We underrate the significance of symbolic acts and of symbolic representations in our everyday life. As a matter of fact, existence is inconceivable without symbols. Riklin states: "Is not almost every word a symbol? The writing signs are symbols, the words are symbols, our mimicry, our gestures are in great part symbolic. A geographic chart is a symbol. Noteworthy are the meaningful abstract symbols: God's eye, the scales (as, of justice, for instance), the cross; the color symbols : black, red; the symbolism of uniforms, etc."

What tremendous power belongs in the first place to the sexual symbol. It pervades our whole life. There is no object, which under certain circumstances may not represent a sexual symbol. A particular intonation, a deliberate gesture, a wink of 
the eye accompanying an innocent remark may give the latter a "double meaning."

Sexual symbolism is the key which unravels for us the various myths of the different races. Also the religious formulations. A striking example of the latter we have in the concept of the snake, which plays also a great rôle in folklore. A snake seduced

- Eve in paradise. The snake appears to young girls (Oda and the Snake, Bechstein), and when the latter overcome their revulsion and take the cold snake into their bed ... the snake suddenly changes into a wonderful prince who had been bewitched. The - slippery, cold, ugly snake is a sexual symbol, like the ugly toad, which climbs into the bed of the king's daughter (Der Froschkönig and Der Arme Heinrich, of Grimm). Here, too, the overcoming of disgust is rewarded with the presence of a wonderful prince. Further illustrations of this type may be found in Riklin's work already mentioned.

What the fairy stories mean to the individual, that the folk story or myth represents in its relations to the folk mind. The myth is a folk dream and contains in a cryptic symbolic language and expression of the unconscious wish-excitations and fulfillment-hallucinations of the folk mind. The myth, too, contains a more or less cryptic, sometimes fairly overt and rather obvious, sexual symbolism which is remarkably like the similar dream symbolism,-a 
fact convincingly brought out by Abraham in his interesting study in folk psychology entitled Traum und Mythus (Dream and Myth).

The study of these myths has long been assiduously cultivated by the folk-psychologists who justifiedly expected to find through them a path towards a better understanding of the mental life of the various people. Just as dreams disclose the secret thoughts of the individual man, so myths must disclose in unmistakable manner the ideals and wishes of the people. It turns out that a number of myths which have appeared at different times among the most varied nations on earth show a remarkable similarity between them so that some investigators were led to conclude that the formation of myths depends on mental processes common to all mankind. On the other hand, many other investigators held that the similarity of myths is due to transference,-a borrowing or transferring of the same myth material. What was lacking until recently in the investigation of the problem of myths was an appreciation of the parables between the process of myth formation and the mental life of the individual. The bridging over of the two realms of inquiry,the world of individual dreams and the sphere of folk dreams as represented in myths,-represents a gigantic step forward.

It is pleasing to record that the connecting links 
between the social and the individual activities of the psyche have been successfully revealed at least in one limited field, namely, The Myth of the Birth of the Hero, in a study under that title, by Otto Rank, to whom we were already indebted for another excellent study, The Artist (Der Künstler, Wien und Leipzig, 1907). Rank points out very convincingly the similarities between the phantasies of individuals and the folk phantasies as revealed in a series of birth myths.

We want to lay stress on the mere fact of this parallelism: for dreams and myths, fairy and traditional stories present the same kind of psychic structure. One may contend that the myths about heroes were conceived originally by poets, while fairy stories are creations of the poetic genius of the whole people. Such a contention may be met best with Hebbel's fitting words: in den Dichtern träumt die Menschheit, -rohole humanity dreams through its poets.

An almost inexhaustible fund of material for symbolism is to be found in the collections gathered by the well-known folklorist $F$. S. Krauss and his coworkers, and published under the title Anthropophyteia (Leipzig, Deutsche Verlagsaktiengesellschaft). The tremendous material gathered therein awaits systematic elaboration in the light of dream symbolism. Occasionally I shall refer to the similarities between folk language and the symbolism of 
dreams. The formations of wit, too, reveal to us the operations of the unconscious. ${ }^{11}$

I have thus far indicated only a few simple examples illustrating the significance of sexual symbolism. It is not possible to give an account of a dream analysis without touching on eroticism. There is, in fact, no anerotic dream.

The power of the sexual instinct is so tremendous that it probably never leaves us out of its grip even for a few seconds of time. We shall see later, when we consider the subject of half dreaming, of hypnagogic pictures (dream pictures before falling asleep, or just before fully waking up, during the so-called "twilight" states) that the sexual instinct is momentarily ready to take possession of man's psyche.

The symbolism of dreams is chiefly sexual. Though the erotic plays a predominating rôle in the pages which follow it is not my fault. I cannot do otherwise than present the material as it reveals itself.

There is another factor which plays a tremendous rôle in the dream life: the criminal tendency. The cryptic criminal roithin us reveals itself in our dream. But the criminal tendency stands nearly always in the service of the sexual. Perhaps every criminal is a sexual criminal-possibly. I expect

"Cf. Freud, Wit and Its Relation to the Unconscious (Translation by Brill, Moffat, Yard \& Co.). 
to prove in the following chapters of this work that the investigator is not responsible for the presence of the erotic features. We do not lay stress on it deliberately. It is there. Whoever is endowed with unencumbered eyes cannot fail to see that symbolism plays the most important rôle in our mental life.

Why do persons make free use of symbolism in witticisms and why do they usually display such a keen appreciation of the symbolic shadings of meaning employed by the flirt? Hitschmann rightfully observes ${ }^{12}$ that, "in the cynical gathering of male festivities, or cabarets, or when reading the humorous papers the same persons suddenly display sufficient insight into sexual symbolism!"

What would be the sense of avoiding these facts of life simply because we do not like them? This book is a record of facts. ..

The ancient, eternal struggle between instinct and society, between mine and thine (Otto Gross) does not cease in the dream. The wish fulfillment, postulated by Freud, may also be a wish fulfillment of the moral self.

But there are many dreams which do not fit within the range of wish fulfillment, even though we conceive the "conscience dreams" as wishes of the moral self. There are, above all, the telepathic

12 Hitschmann, Freud's Theories of the Neuroses (translated by Charles $R$. Payne, Moffat, Yard \& Co.). 
dreams: no objective investigator can doubt any longer their existence or validity.

Enforced with a knowledge of these facts, we now turn our attention to the analysis of a more complex dream. 



\section{II}

THE ANALYSIS OF A SIMPLE DREAM-THE DREAM ABOUT THE TELEPHONE-THE BALLAD OF THE POOR EAGLE-WHAT MRS. A. THINKS OF THE ACT OF TELEPHONING 



\section{II}

Hebbel in his diaries remarks: "A man making up his mind to record faithfully and with regularity all his dreams, without choice or scruples, and adding thereto a commentary to include everything from his life or reading bearing on the explanation of his dreams would render a great service to humanity. But as humanity stands to-day, it is not likely that any one will undertake to do it; still it would be worth while for some one to try it as a matter of personal choice."

I have seen such diaries. They are not very useful because we are unacquainted with the dreamer's cryptic symbolism.

The great advance of the Freudian dream interpretation consists precisely in the fact that it has added a novel aid to the art of interpreting the dreams: the dreamer's thought reactions. The dream material which evoked the dream comes back to the dreamer's mind through free associations.

But the thoughts sometimes do not come up freely. It repeatedly happens that on account of inner resistances the dream parts evoke no associations in the dreamer's mind. A knowledge of the dream 
language and symbolisms helps us over such "dead" points. The simpler the mental life of a person the simpler also are that person's dreams. A great many dreams do fit to Hebbel's plan. If we know the dreamer's life, we know also what the dreams portray. There are also dreams which betray their meaning even before we have become acquainted with the dreamer's life history.

Here is where my investigations deviate from Freud. Freud places the greatest emphasis on the material found back of the manifest dream content. I have endeavored to prove that the manifest dream material itself displays the most important content, the latent dream thoughts. With this conception I have achieved surprising results. I have discovered relationships (for instance, the symbolism of death) which I would have never unearthed through the dreamer's thought associations. That is not the case with every dream. For as already stated:

The dreams are variously constructed. Simple folk have different dreams than sophisticated people. The dream consists of separate dream parts which group themselves into a whole,-into a single dream picture. The analysis of a dream must proceed from the separate dream parts.

But how is the dream element to be interpreted? What is its meaning? What its relationship to wish fulfillment?

"Usually, in the case of a dream element, it is 
a question," states Freud, "whether it should be taken:

" $(a)$ in a positive or negative sense (antithetical relationship);

"(b) in a historic sense (as reminiscence);

"(c) symbolically; or whether

"(d) the meaning should be traced to the word sounds."

In spite of this manifold possibility of interpretation, it must be observed that the unraveling of the dream work, which does not aim to be understood, presents no greater difficulties to the translator than the old hieroglyphic writings, for instance, raise for their readers." (The Interpretation of Dreams, authorized translation by A. Brill.)

The dreams are various. Some are shadowy and intricate and require long and persistent scrutiny. The dream may be reduced to its component parts only with the aid of the greatest finesse. As a light educational example let us analyze a phantasy dream, which reduces itself, in fact, to a single symbolization.

There are also dreams which may be cleared up with a single key. When, for instance,

(12) A woman goes to the butcher shop, to make some purchases, finds the meat stall exposed, chooses a big, hard piece of meat, shaped as a sausage 
(Wurst), shoves it in her pocket, where it hardly fits, as it melts in the warmth of the pocket, every detail of the dream is obvious when we know that it relates to fleischliche Gelüste, lusts of the flesh, and to purchases in the love mart. I want to record here a dream of this character, in which the telephone has an erotic meaning. It is a long and spectacular dream, containing numerous details which, naturally, are also significant for the analysis but which I must overlook for the present. This dream is also noteworthy because it ends with a poetic production. Poetry is not uncommon in dreams. Occasional verses are produced in dreams and sometimes they are rather well done. I must forego for the present the temptation of taking up the subject of poetic productions in dreams. Poetry and dreams are alike products of the unconscious ${ }^{1}$ and naturally show inner relationship.

The pleasant dream of Mrs. Alpha, which ends in a ballad, reads : ${ }^{2}$

(13) I visit my sister and find only my brother-inlare at home. The telephone rings. Astonished, I wonder since when the instrument had "been introduced into the house. My brother-in-lawe throwes

${ }^{1} C f$. my Study entitled Poetry and Neurosis (authorised English Version by James S. Van Teslaar).

${ }^{8}$ I take this opportunity to remark that all dreams are recorded exactly as the dreamers have written them down for me. The most trivial colloquialism, an error in spelling, some peculiarity of punctuation-may have great significance for the analysis. 
a deprecating glance at me and asks whether I do not read the daily papers. I answer, saying that I probably do not do so with sufficient attentiveness and ask what that has to do with the telephone. The brother-in-law tells me that the whole telephone system is now undergoing a radical change and since the stupid, unreliable telephone girls have been replaced by men belonging to the best educated circles who have volunteered to take up the service in hourly rotation, there is no more ground for worry or hardships. There is not a decent family in the whole of Vienna reithout its oren telephone and since there are so many subscribers, the cost to each has materially decreased. I perceive at once the advantages of the telephone service and I am enthusiastic about securing it at once. "A fool, whoever has no telephone," I exclaim very eagerly and ask about the charges. "Only one hundred kronen per year," says my brother-in-law. "Ridiculous, so small a charge," I declare, convinced, as I am already, and miraculously extract from my pocketbook, usually empty, a banknote of the required denomination. $I$ press impatiently for the prompt acceptance of my subscription. My brother-in-law takes the money and I hear him negotiate over the telephone. A gentleman appears, beardless, dark, small, with a repulsive exterior and threatening loud voice. He introduces himself as a bass singer of the Court Opera and states that he is the man in charge of 
my telephone number. My brother-in-law takes me aside and advises me to be very courteous with the man and to invite him occasionally to an evening meal and I will then be treated with better consideration. I tell him frankly that I cannot bear that terrible man's voice and I would rather give up the telephone than have that horrible fellow shout into my ears in the future. "Give me back my money," I say to him, disappointed. "That I cannot do, I have paid it in already," is rohat I am answered. With me it is always but a step from the highest happiness to the depths of despair and, disconsolate, now that I am burdened with the telephone, I ask rothether I could not have the Opera Tenor assigned to me. Tenors have voices that are much more pleasant to hear. Again a man appears, stout, beardless, with red cheeks, introduces himself as the Imperial Opera tenor, and inquires about the telephone. I declare at once that his organ pleases me better than the other man's, and that I am very desirous to exchange the gentlemen. This man is accompanied by a woman wohom he introduces to me as his sister, an actress. He looks up my brotherin-law and the bass singer to negotiate the exchange with the latter. The bass singer does it with obvious ill grace and presently, after an exchange of some angry roords, the meaning of which I do not perceive, $I$ see the bass singer muttering insults as he leaves. My misfortune is over, and overflowing 
with happiness, I now ask the lady and gentleman to be seated. I try to be courteous and, mindful of brother-in-law's advice, I extend my invitation for supper, which is eagerly accepted. "What happy evenings we shall have," I think to myself, charmed. The actress holds out the promise of reciting occasionally and my joy is boundless. "In fact, if you roish to hear me, I reill gladly recite you something right nowe," says the charming creature and begins. It is an unknown poem by Baumbach, called Der Arme Igel, The Poor Eagle, and I listen to its recital with the greatest interest. Then $I$ roake up and I note down the poem. ${ }^{3}$

This dream, apparently so happy and filled with humor embodies the tragedy of a life. The ballad of the poor eagle is the story of her marriage. She is unhappily married. She dislikes her husband; she cannot endure his tendernesses. When he attempts coitus, she begins to cry out in the middle of the act and pushes him away from her. She is afraid of her own libido. If she could give herself without libidinous excitation she would do so. But because she does not want to be roused by him she repulses her husband during the sexual embrace. She has thought out all sorts of excuses to keep him at a distance. One day she has migraine, another day influenza, a third day she is perhaps just

'The original of the poem is reproduced at the end of the chapter. 
beginning to menstruate and this keeps up for weeks in her case, which of course cannot be true. Finally the fear of her husband's embrace became an obsessive thought-feeling with her and she fled into a severe neurosis, which made it possible for her to live an abstinent existence. That her prudery is directed only towards her husband, for whom "fear has repressed love" as the poem expresses it,is shown by the analysis of the telephone dream and of her other dreams. One of her earlier dreams which she brought to me, dealt with a very significant situation. The man whom she truly loved but did not marry was in her bed and acted as her ardent and tireless lover. I step in but the loving pair are not disturbed and thereupon I quote the verse:

Zur Liebe ist es nie zu spät, Wis man es jetzt gesehen hat.

The lover retorts at that:

Heil! Heil! Heil!

Schön ist ihr Hinterteil."

Her sexual aversion, therefore, is directed only against her poor husband, whom she consciously dislikes. In the sad ballad she even has him become insane and die off in three days.

That has a deep meaning. The man, in fact, is

The lady subject who relates this dream has the habit and the ready knack of improvising verses, and can speak in rhymes for days. The composition of the ballad in the dream is therefore natural in her case. 
not normal and suffers of a mild progressive paralysis. Their family physician states that he may last possibly another three years.

Her first love was a tenor. That explains the contrast between bass and tenor in that long dream picture. Her husband has a deep sonorous bass voice, which sounds painful in her ears and seems disgusting to her. She has accustomed herself to disregard his voice entirely. She simply does not hear when he speaks.

That explains the telephone dream. The sexual symbolism of the telephone was well known for a time in Vienna and actually current. In one of the popular amusement places devoted to the lighter Muse a well-known soubrette sang for a year or more a telephone song full of pointed hints. It was, in fact, a plain description of the sexual act, in which the various technical terms of telephony were employed with remarkable pointedness. A young man wishes to learn the art of telephony. The girl who has the apparatus in charge gives him the "receiver" in hand, he calls up, central answers; he wants another "number," and telephones so excitedly that he nearly wrecks the apparatus, etc.

The same sexual symbolism gives the key for the understanding of this dream.

The dream begins with incest thoughts about the brother-in-law who is very happy in his married life. She finds him alone in the house and the telephone 
rings at once, that is, her sexual longings are roused. The brother-in-law, heretofore a solid, conservative Catholic, opposed to all reform movements likely to weaken Catholic rigor of the marriage ties, that same brother-in-law who refuses to read the daily papers devoted to progress, that confirmed clericalminded fellow, now tells her that the sexual life of humanity is being placed on another, modern basis. This refers to the oft-mentioned theme of free love. Men of good standing, cultured men (what a contrast to her husband) are volunteering to give telephone service and hourly take their turns at it. We note this to be a sort of male service, the man weakened by telephoning being at once replaced by another. There are thus no fears and no hardships any more, as with her husband, whose potence appears terribly ill adjusted to his appetite.

The act of "telephoning" is no longer indecent. On the contrary, there is no decent family in the whole city of Vienna without its own telephone. The guilt is smaller in any individual instance, the larger the number of sinners (the number of subscribers is tremendous; therefore the cost is correspondingly lowered). She, too, pays one hundred kronen for a Sprachrohr (literally, a speaking tube.) ${ }^{5}$ That was theretofore the price of an auto-

"The Sprachrohr, literally "speaking tube," of course, is a symbol for the penis. We note in this connection the tendency of the dream to express all sexual dreams as bisexual, a 
matic telephone (that is, masturbation-automatically used sexuality-auto-erotism). My last bill, too, amounted to one hundred kronen, showing that the brother-in-law of the dream is a fusion of myself and the brother-in-law. This process whereby two or more persons or incidents are fused in one picture will be referred to repeatedly in our work. Noteworthy also is the pocket, "usually empty," which means, the empty vagina, which would secure for itself a respectable sympathetic male through purchase. The brother-in-law negotiates the subscription to the telephone. First there appears her own husband; she was put in his charge-the brother-in-law had witnessed her engagement (my telephone number was put in his charge). The advice to invite him to evening meals shows the connections between eating and sexuality. ${ }^{6}$ Evening meals here means night's lodgings. But she prefers to give up her telephone. That really corresponds to the actual facts in the case, as we have suspected from the first. She is dissatisfied, she wants her money back (meaning here the dowry, which has been meanwhile squandered away), she wants a separation, a step which her Catholic brother-in-law has thus far used his whole influence to prevent.

tendency which we shall have repeatedly occasion to point out. The telephone has a transmitter and a receiver.

- Frequently, in German, "einen zum Abendbrot einladen," used in same sense. 
The pleasing tenor, so willing to accept the invitation to supper, who appears next, she finds very agreeable. She would like to exchange her husband for him. The man whom she likes so well is unfortunately married. ( $\mathrm{He}$ is accompanied always by a lady.) In the dream she turns the antagonistic woman into a very loving sister, in accordance with her wish. The "actress" is a reproach against the tenor's wife and means: she is a comedian and makes a fool of you! The bass singer disappears at last, muttering harsh words; she is very courteous and invites the gentleman to supper. She thus has a man and a woman at her disposal. The picture very clearly hints at the patient's homosexual inclinations. Both erotic components, her homoand her heterosexuality are coming into play. We now understand her enthusiastic feeling: "Nein! Werden das genussreiche Abende sein. My! what pleasurable evenings we shall have."

The actress will also recite, an act which, clearly bears the same cryptic meaning as "telephoning."

That charming creature now recites the poem implying scorn for her husband and culminating in the thought that an eagle belongs only to an eagle.

Further analysis shows that she herself is that charming creature. She had been often so called, 
as a girl. She identifies herself with the wife of the beloved man. ${ }^{7}$

Finally the act of "telephoning," has also another meaning which is well known to her. In congress $u$ the constrictor cunnei was excited into action at first and the husband responded with a corresponding muscular motion. During the first part of her married life she was happy and . . . "telephoned." Soon afterwards the libido disappeared during the act, being replaced by a dread of the libido. The "telephoning" ceased. ${ }^{8}$

Naturally the dream reveals many other associations. But it is not necessary for us to dwell longer on this dream and instead we turn our attention to other analyses. One further remark I may offer with regard to the character of the dream. I have called it a phantasy dream. It means that this dream clearly represents the transposition of a daydream into a slightly veiled form of dream language. This type of dream is very frequently found among hystericals. The dreams of this type do not tax at all the interpreter's ingenuity.

'Here we see a proof of her strong self-love, the so-called narcissism, which was indicated also in connection with the "automatic telephone."

-The telephone symbolism links up through associations with receiver, in technical sense. In vol. VI of Anthropophyteia, Dr. Aigremont has published a very instructive essay on Muschel und Schnecke als Symbole der Vulva ehemals und jetzt. The Schnecke, moreover, is a bisexual symbol and as Schneck stands for the penis. 


\section{DER ARME IGEL}

\section{(Ballade)}

Ein Igel fand gefallen

Einst an der Jungfer Maus,

Der putzigsten von allen

Im kinderreichen Haus

Beim guten Feldmausvater,

Dem Wirt: "Zum schwarzen Kater."

Da hielt, wie sich gebiihret, Um Mausi Igel an,

Der Vater ward gerïhret,

Gab seinen Segen dann.

Und selig führt die liebe Maus

Der Igel in sein Igelhaus.

Im Rausch des Glïcks versunken, Voll Zärtlichkeit den Sinn, Naht er sich Liebestrunken

Der süssen Mäuselin.

Sein Herz schlug vor Verlangen

Sie liebend zu empfangen.

Kaum hat er sie umfasset

Mit treuem, starkem Arm,

Voll Schreck er von ihr lasset,

Sie piepst, das Gott erbarm.

Doch reird's dabei dem Ehmann klar,

Dass er als Igel stachlig war. 
Trotz aller Liebesgluten

Blieb Igels Glïck beschränkt;

Es hat bei Maus, der guten,

Die Furcht die Lieb' verdrängt

Und nimmer durft, o-wehe

Der Maus er in die Nähe

Dem Igel stieg zu Kopfe

Der Stachelunglückswahn,

Er ward zum irren Tropfe

Und kränkelnd starb er dran;

Man hat nach dreien Tagen

$\boldsymbol{Z} u$ Grabe ihn getragen.

Moral:

Drum Igel frei in klugem Sinn

Stets nur um eine Igelin. 


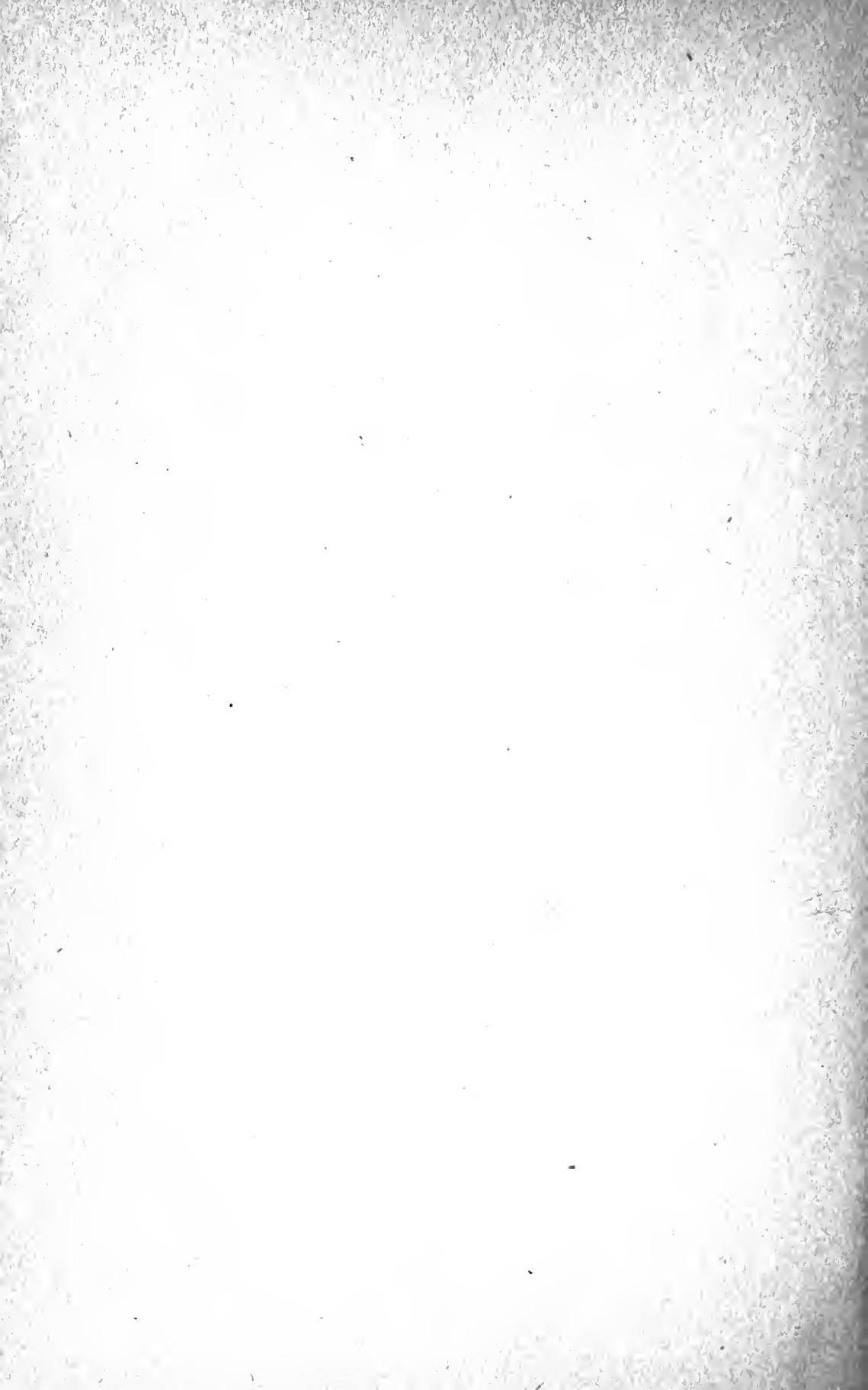




\section{III}

SUPERFICIAL ASPECTS OF DREAM INTERPRETATION-

THE MOON AND THE EARTH-THE "RATHAUS" DREAM-REPRESENTATION OF UNBRIDLED IIFE 
Suche in das Innere jedes Menschen einzudringen; aber gestatte auch jedem anderen in deine Seele einzugehen. 


\section{UII}

[Endeavor to penetrate into every one's inner self; but allow also the others to look into your soul.]

Marcus Aurelius.

Let us endeavor once more to bring into relief the superficial aspects of dream life through the analysis of a few examples. We turn our attention again to a dream which portrays but a simple symbolism.

The following is a dream of Miss Gamma:

(14) A laundry bag in my hand. I have emptied it. It was full of dirty, gray linen. A pillow case, gray dirty, sanitary napkins (way below), a whole pack of them-everything disgusting. I had to empty everything.

A symbolic representation of her psychoanalytic treatment. She washes her dirty linen before me. During the last consultation hour she told me about her menstruation difficulties; the pillow case refers to certain intimate doings which took place in bed. She has a great disgust for such things. But she has the feeling that she must tell everything (empty entirely the laundry bag) so as to get over her troubles once for all. All her thoughts center on the 
notions of "clean" and "unclean." She is at present taking care of a sort of Mohrenwasche. Es graut ihr davor,-she abhors it. (Here, a play on the double meaning of grau, gray, and grauen, aversion, horror; a reference to the dirty linen as well as to her horror and disgust.) The whole dream is a typical symbolic transposition of her waking thoughts.

But that interpretation corresponds only to the most superficial layer of the dream. It embodies some of the recent occurrences. But every dream derives its stimuli from various layers before it becomes a more or less loosely knit unit. It is overdetermined (überdeterminiert, Freud) and yields additional meaning. It contains also an infantile root.

The earlier layers of the dreamer's associations relate to her sensations during her first menstruation. She thought she was unclean. (Among some people the menstruating woman is considered unclean and is taboo for a time.) Further associations lead to her youth, when she remembers having searched the parents' bed linen for such spots. Finally there come to surface infantile reminiscences which show that her disgust of dirt was preceded by a period of intensive mysophilia.

Further associations to laundry sack lead to a sack of a different kind-the scrotum. Two serious traumas reveal themselves to her mind's eye. An uncle gave her to hold his phallus. The recall of 
the ejaculation (I had to empty out everything) is associated with a strong reaction of disgust. An earlier reminiscence relates to a similar incident in which her younger brother figured. Noticeable once more is the bisexual use of laundry sack, which as symbol is associated with the practice of masturbation.

We shall not tarry but instead will proceed to some other "superficial" analyses. For the most part we shall limit ourselves to the uppermost layers of associations.

We have spoken of the simple process of wish fulfillment in fairy stories. A child appears to the mother begging her to weep no more. Her tears disturbs the child's peace in the grave. I want to relate now a similar "consolation" dream. An elderly woman who has lost her husband two years previously dreams:

(15) Our dog, old and useless I see lying on the sof $a$ and breathing his last. My son-in-laze suddenly comes home bringing along a little, lovely brown dog. I ask him, "Consoling yourself as soon as that?" He raises his shoulders saying: "Why not? What is the use to keep on mourning. One must learn to accept the inevitable."

The woman had this dream on the anniversary of her husband's death. For two years the widow had worn mourning and permitted herself no distraction. In the dream her son-in-law represents 
her own sober judgment: Don't mourn any longer! What comes of this everlasting mourning? Do the way wise folks are doing.

The objectification of one's own thoughts through another person is extremely common. Other thoughts, too, suggest themselves through the dream. The old (dog, as sign of scorn) is dead, take another. Further, the fearsome thought, the son-in-law could easily console himself, if his wife (her young, brunette daughter) was to pass away. ... .

But for the present we still limit ourselves to the superficial meaning disclosed by the simplest associations.

A very fine, artistically-inclined girl tells me that she has had during the previous night a "wonderfully beautiful poetic dream," which has made a lasting impression upon her. She tells me the dream and also writes it out at my request:

(16) It seems I had already been with a couple of girls in a train, namely at the open door, and there was a vague feeling that $I$ was in some harmonic relationship rith one $J . K$., and there was also something between $H$. (the other girl) and myself.

Am sitting later in a large third class compart. ment, near the window, far forward (in the direction of the train) and to the left, back to back with the two. Moreover, it seems there is no one else in the compartment. 
I stand up and through the window I look upon the moon hovering in the shape of a gigantic egg yolk, somerwhat double her customary size. To the left of it a luminous ring fitting it, much like the Saturn rings.

I make some remark about how strange it is that the moon should hover so close to the railroad track, and $H$. answered saying that it roas but an optical illusion. "Is that so," I say. "I am going to find out," and I lean forward to catch the moon with both hands and drare it into the compartment. The ring around it I disregarded, it moved along.

But under my hands the moon was elastic and wavered around. It felt like the pretty yolk swimming in a plateful of soup when one tries to squeeze it with the spoon and the egg yolk cannot be broken and it resumes its shape every time.

I gave it up and fell back on my seat exhausted, thinking how presumptuous it would be for me to draw the moon inside and rob the earth of its moon, and I don't know whether I actually said so, but $H$., at any rate, seemed to say to me: daring it would not be. Only you're inexperienced and don't understand as yet the relations of things. She referred distinctly to physiologic relations. Everything is intertwined with endless threads into everything else and reverts back to itself again.

I seated myself again, keeping silent, but thinking: how strange and comical. 
This "innocent dream of a virgin" enables one to depict the state of her mind. One finds that she already dimly perceives a great deal and she holds herself back from certain knowledge. The fitting of one thing into another is perceived as "psychological" and the organic aspect is suppressed. One also notes that she perceives these excitations as sinful and she envies her friend $H$., the simple sweet girl, who has a lover, on account of the latter's experiences. The dream does not expose a riddle: it depicts merely a simple, romantically disposed un-

- gratified person. I state anticipatively that the picture of the moon was soon found to be a symbolism for penis and testicles.

The ring is the engagement ring. She neglects the ring later. She is, therefore, prepared to consider extramarital coitus, like her friend $H$. The statement, "You don't understand that. Everything is intertwined with endless threads (spermal threads) into everything else and reverts back to itself," is particularly striking. It is noteworthy also that her compartment is a Durchgangscoupé, a "passage" compartment. The vulgar term for testicles comes to surface in the "Eidotter," the egg yolk.

Miss Gamma relates an almost identical dream:

(17) I saw floating in the air a great globe, surrounded with a ring of blue glass, like a wheel.

The meaning is the same. Her mother's mar- 
riage ring has a wonderful blue stone. The ring on the finger is a symbol of sexual union. The minister puts the ring on the bride's finger; that is, she may now become acquainted with the marital act. In both dreams we find the bisexual symbol: the globe and the ring,-in a word the lingam.

Another genital symbolism is revealed by the dream of $J . N$., a widow:

(18) I am in the market shopping. Folks going home. Lights are being put out. We went to the checking room. My umbrella is not there-is missing,-another one is there with a broken handle. The handle is like a Polish Jew-with a great corkscrew nose. I take it in hand to try it out and to see whether I could lean on it and think to myself: the umbrella is not so bad as it appears to be.

The umbrella is a common phallic symbol. Open- . ing it up corresponds to erection. The poor woman had lost her husband (light going out). She has no umbrella any more (my umbrella is not there). Her best friend is a Jew. (The "broken handle" and the "cut" handle are play words on circumcision.) The meaning of the dream is: "In case of need the devil eats flies. Try the Jew; he is your only consolation in your misery. Perhaps he turns out better than you think."

Somewhat more complicated is the next dream, related to me by $X . Z$., a philosopher:

(19) I dream of a triangle supposed to symbolize 
some pinilosophic principle and which serves me, perhaps others also, as a sort of support. The triangle growes gradually smaller and more angular finally it is but a spear and therefore it is no longer fit to serve as a support and $I$ am about to fall into a terrible abyss. I awake with a terrible loud outcry and all my body is shaking.

He lives with a married couple. The man is his best friend. He maintains a triangular relationship. The friend is the basis of that relationship. That basis disappears, that is, the friend dies. $\mathrm{He}$ unites himself with the woman. The death is supposed to have been deliberately induced. $\mathrm{He}$ has murderous thoughts (spear, Spiess-Spiessgeselle), and the fall into the abyss is the terrific crime of which his most secret self is dreaming. The lingam after the death of the husband explains the riddle of a unit growing out of a triangle. Associations lead here upon the path of religious scruples (trinity). The philosophic thoughts are masked erotic wishes. Deeper layers reveal the relationship of the child to the parents.

Mr. Dalton dreams :

(20) I have two different shoes: a yellow one on the left foot, on the right, a black one.

He loves two women: one is blond, the other is dark. More significant yet the meaning: schroarzgelb, yellowish-black. $\mathrm{He}$ is an Austrian and wears on his feet the colors of his emperor (father). He 
is a typical skeptic. He vacillates continuously between man (the dark father) and woman (the blond mother). His desire is to satisfy both. . . . His psychic hermaphroditism (Adler) is wonderfully well expressed in this picture. Also his most powerful passions: jealousy (yellow) and his dark thought of revenge (black).

Sometimes a dream brings to light unusual wish fulfillments. It mediates transposing sinful wishes into respectable realities. A prudish woman, much devoted to her husband, is interested in a young writer. She would like to meet him. The dream conjures up the desired opportunity. She dreams:

(21) I am confined to bed after a serious internal operation. My husband stands at the head of the bed, looking at me sympathetically and kindly, his hand on my shoulder. Bending over me and looking me straight in the eye is the young poet. I am coming out of narcosis or out of a deep slumber. Seeing my husband and the poet, I feel in the dream that the blood is rushing to my cheeks and I say to the poet: "You here!" He gazes lovingly at me and exclaims: "Thank God! She is saved." "And you, how do you happen to be here, now?" I ask. "I am a physician, madam," he says, "I have assisted at the operation." My cheeks redden, I turn my head siderways and hide in the pillowes and shut my eyes.

All wishes are gratified. She has a wonderful 
white body. The poet is physician and has seen her naked. He has operated on her, he has saved her (both symbolic expressions for sexual congress). Everything occurred in respectable fashion. Her husband was present. Her bashfulness was not violated at all. Everything occurred during narcosis. ${ }^{1}$

One of the following dreams (24) brings up a similar situation under neurotic distortion.

We turn our attention now to the analysis of a beautiful, so-called political dream.

The dream is a very lively one and permits a clear insight into the most common forms of dream symbolism.

The dream of the (Rathaus) Assembly House:

(22) Great uproar in the Assembly House. The Emperor is also present. Thousands of people below, awaiting the Emperor's departure. It is evening and the Assembly House square is feerically illumined for the occasion. Three figures stand watch in front of the main entrance. In the middle stands a gigantic figure dressed as the iron man, a blinding white light emanating from him. At the right and at the left each a figure similarly clad in golden attire. These two are very quiet, almost motionless, but the iron man is nervous, he is impatient for the moment to arrive when he should

${ }^{1}$ I have known for a long time that the post-narcotic neuroses and psychoses are traceable back to such unconscious phantasies involving violence. $C f$. similar example in my Nervöse Angstzustände, p. 96. 
cry out to the assembled populace, the Emperor is coming!-The people have been waiting for hours. $I$ and $a$ few others,-were lucky enough to be admitted roithin. We shall see the Emperor at close range,-the thought causes my heart to beat fast. I become very nervous and I run breathlessly up and down the steps. I am a prey of undescribable excitement; suddenly I hear a tremendous noise rising outside, like the roar of an oceantide breaking against the wonderful building and echoing within. Scared, I ask the servant rohat happened. He says: "The three at the door got tired roaiting and left their post swearing at the Assembly House, the people became more impatient than ever at that, hence their outcries." At that moment the hall doors are thrown open, an ocean of light assaults my eyes. I see the burgomaster (mayor) with the great golden chain and the red colored order ribbons hurrying down the steps; he passes very close to me, so that I can almost feel his breath; he draws me along, I run after him, the great door of the hall springs ajar, as if opened by magic hands. The burgomaster calls excitedly: "Where is the Emperor?" He is told the Emperor had left the Assembly House through a side door and was being carried along the Burg theater (Municipal Theater Building). I see very clearly the carriage disappearing in the midst of the crowd. But no sound is now heard . . . then I aroake. 
The dream of a poet, full of dramatic incidents, of plastic imageries, and apparently dealing with political conditions. It was dreamed by a young man who expects to marry a poor girl. His parents are against it. His father (the Emperor) is now helpless and dependent upon him for support. On the evening before the dream he kept reflecting for a long time how he might extricate himself from the unpleasant situation. The dream has shown him a solution. In the girl's house wo er sich gut beraten roähnt (Rathaus) where he considers himself well counseled, a great reception is being held. The analysis brings up by association a dance, a marriage ceremony. $\mathrm{He}$ is getting married (Empfängniss, reception). But the father (Emperor) must first leave (abfahren, sterben, die) then the stumblingblock will be out of the way. A death wish against the father. The tremendous mass of people, the contrary circumstances. Three guardians are watching before at the Assembly House. The iron man is again the father (iiberlebensgrosse, unnaturally big) who in spite of his vigor earns nothing. Hence the vigor. The blinding white light which emanates from him is a scornful reference to his bald pate and his limited, homely, philistine intellect. The quiet figure in golden accouterments is his precious, dear mother (also doubled) who does not reproach him; the iron man (iron constitution) is nervous and always plays the rôle of the house 
tyrant: the Emperor is coming! This remarkable dream structure carries out further the feelings in the breast of the young man; the father must give the deciding word, the circumstances speak loudly their unfavorable tone. The father has lost his position as employee (the watchmen at the gate abandon their post), that is why the circumstances have become unbearable. Now comes the wish fulfillment in glorious form. An ocean of light blinds his eyes. The burgomaster (mayor) is his sweetheart, the mistress of his heart, the golden chain, the marriage tie, and the red order insignia - these, analysis finds to stand for blood. How does he describe the power of attraction which the beloved exercises over him? "I almost feel his (her) breath, he (she) drags me along, I follow him (her), all obstacles are overcome, the gate door of the great house springs ajar as if opened by magic hands." The Emperor is carried across the Municipal Theater. On that square he saw a few days ago a great funeral procession. The Municipal Theater as symbol for the parental home is now conquered region. Emperor and Burg theater, both are overcome.

He was tremendously excited in the dream. But in ordinary life Emperor and Burgomaster do not affect him. Only because here they are symbols, because the Emperor represents his greatest obstacle and the burgomaster symbolizes his most cherished ideal, his beloved, are these dream thoughts linked 
to such tremendous affects. Very interesting is the observation: The burgomaster calls out excitedly: where is the Emperor? That is the very climax of the little drama which is portrayed before us, the great scene between the father and the beloved. Naturally she is the one who comes out victorious.

But any one who thinks this analysis is at all exhaustive is badly mistaken. The dream shows us the problem of his love affair. He has carried out an identification of his mother with the beloved. The Assembly House stands for the mother as well as for the bride; it signifies the beloved mother, or the beloved, who shall be the mother of his children. The mother receives the father (Emperor)-naturally evening. The mass of people signify the rebellious wishes, the numberless evil thoughts, and for that reason, naturally, by way of contrast, a secret. The three figures on guard, symbolize, like most trinities, the penis and pair of testicles. Here the penis is the "iron man" with the lance; the testicles (egg-yellow) are characterized by golden garments. ${ }^{2}$ One on the right, the other, on the left. It is an old dream symbolism that the father means also the generating one, that is, the penis. The testicles are naturally immovable, quiet, only the penis is impatient for the "arrival."

$I$ and $a$ few others-we are lucky to be allowed

"The "golden balls" as testicles: Anthropophyteia, vol. II., p. 142. 
to get in. ${ }^{3}$ Naturally, he was within the maternal body. The past becomes the present. (This theme,-maternal body phantasies-will preoccupy us at different times in the course of our present study.)

The wishes become progressively more pressing. Another's three-become his trinity. ${ }^{4}$ The Emperor leaves through a side door (that is, he dies, his carriage disappears in the crowd). The situation resembles more closely the act of coitus (up and down the steps) - and the dreamer wakes up.

The birth phantasy naturally commingles with the defloration phantasy. He does not want to wait so long. The iron man is impatient.

Another picture:

The Dream of the Unbridled Life:

(23) I am in a street car which is bound for the Franz-Joseph Station. One horse is harnessed with a bridle of thin rope. The rope breaks.

This dream I dreamed in the fall after the return of my wife through the Franz-Joseph Station from a Summer vacation. A clear wish fulfillment, to continue the care-free existence of a "grass" widower

There are three children in the family.

- Interesting material on symbolism is found in the work entitled, Ancient, Pagan and Modern Christian Symbolism, by Thomas Jnman, M.D. (2d ed., New York, Peter Ecker, Publisher). According to this author the cross represents the union of 4 phalli, it is of Phoenician origin and has nothing to do with the essence of Christianity. In the beginning the cross represented the fusion of trinity and unity. It is a symbol commonly met in Egyptian art. 
(expressed in one of the slang popular songs of a few years ago, in the sentiment: "My wife has gone to the Country, hurrah, hurrah!") obviously the welling up of an unconscious thought. In reality I was happy for my wife to take again the household affairs in hand so that $I$ could live once more under orderly conditions. I had not taken advantage of my supposed state of freedom. But the secret wish must have been there, nevertheless.

Of course, I am the draft horse. That is a common symbol for the husband, in contrast with the woman who is represented preferably as the guardian. The ties which bind me to carriage are represented in this dream as being very weak. The rope breaks (double meaning: the horse, that is, the flighty-minded fellow breaks away). The death wish also shows itself in the dream thoughts. The Parces cut the thread of life. ${ }^{5}$ The thread of life breaks off.

The infantile layer is represented through the Franz-Joseph Station idea (Emperor Franz Joseph -father). I return again to the realm of youth, I return to mother and . . . leave my wife.

"The "life thread" in the folk thought represents also the penis: Anthropophyteia, vol. II, p. 112. The guilty conscience on account of shortening one's life thread or span of existence through masturbation (drawing off the life thread) is also a latent dream thought. Self-reproaches on account of infantile onanism play a great rôle in the neuroses and, like death thoughts, are found in most dreams in caricatured forms diffcult to unravel. 
We have seen that the dream fulfills our secret wishes or ... reveals our secret fears. Fears and wishes are sisters. There is no fear represented in dreams which was not once a wish. In my work, Nervöse Angstzustände, I have proven in connection with a large number of anxiety dreams, that the cryptic wish of neurotics appears in dream as fear or anxiety.

I want to close this chapter with a short but instructive dream which illustrates in very clear manner the bearing on anxiety.

A man, about thirty years of age, suffers of a serious perversion. He craves contact only with children below ten years of age. He has fought against this weakness with energy and successfully. He knew how to control the beast in himself. One of his favorite fancies was to think up situations in which indulgence in his particular perversion would not seem a sinful act. For instance, suppose a highwayman should force him to it . . He would not be responsible and would stand exculpated before human and divine law alike on the score of vis major (coercion).

This man dreams:

(24) I am followed in the open field by a tramp, a very powerful fellow. He has with him a small girl. I was afraid he might force me to have sexual intercourse with the girl, but I thought to myself: I should not really let that weigh very heavily on my 
conscience this time. I ran off and came across some people so that I was saved.

The dreamer, thus, is ready to carry out a sinful act under circumstances which would absolve him from responsibility. He looks for the force majeure of fate, in the form of a Pulcher (Viennese expression for "Strolch"). But even this old wish has now turned into fear on account of inhibitions. ${ }^{6}$

This dream shows the transference of a waking phantasy to the dream life. It illustrates a strange borderland wherein wish and fear commingle in a single affect.

$C f$. the case of a Rabbi in, Nervöse Angstzustände, p. 165. 


\section{IV}

SYMBOLISM OF THE SINKING TREE-REPRESENTATION OF MOTHER EARTH-THE FEAR OF SELF 
Fürchterlich tief leuchtet der Traum in den in uns gebauten Epikurs-und Augiasstall hinein, und wir sehen in der Nacht alle die wilden Grabtiere und Abendröllfe ledig umherstreifen, die am Tage die Vernunft auf die Kette hielt.

[The dream penetrates to gruesome depths into our Epicurean nature, it lights up the Augean stable within us and at night we see, freely prowling around, the wild beasts, the ferocious wolves which reason keeps enchained during the day.]

Jean Paul 


\section{IV}

The examples chosen from the Bible and from Artemidoros as well as various other dreams have shown us that symbolism furnishes the key to dream interpretation. One would think therefore that an accurate knowledge of dream symbols is all that is necessary to enable one to clear up the meaning of any dream. But the matter is not so simple. Now and then it may be possible to recognize the content of a dream merely by a superficial survey of its imagery. But only now and then. Generally it cannot be done. And even if a certain meaning has been recognized what is its value? Every dream has multiple meanings. The dream is distorted through various mechanisms, with some of which we have already become familiar, while others we will learn to know later. According to Freud we must distinguish two categories of data: the manifest dream content and the latent dream content. In many cases the latent content cannot be recognized without the aid of the dreamer. For the symbols have only conditionally a fixed meaning. And anything may serve as a symbol. Also, the symbolism varies with different persons. A violin player uses 
a different symbolic language than a grocer. Every one draws his symbolisms from his own sphere of knowledge. In dream, the father, for instance, is always represented as an authority,-and so most persons think of him as the Kaiser, the chorus singer in the opera as the conductor, the perpetual student as the teacher, the politician as the chairman, the peasant as the government official, the tramp as the officer, the Viennese "Spieser" as the Mayor, the "religious gentleman" as the Pope, although others, too, may represent the father through the Pope (papa).

I have anticipatively made this point so as to guard against a one sided overvaluation of the dream symbols. Now we turn to an apparently easy, simple analysis of a dream:

Mrs. Delta dreams :

(25) I was in an open quadrangular space (it was not an enclosure)-a garden? or a Court?-A tree at one end, slowly disappeared before our eyes, as if gradually sinking into water. I was clever enough to notice that tree and Court alike also underwent $a$ shaking motion: "Here we see how the changes upon the earth surface are brought about."

This dream was followed by another, forgotten dream picture, which ended with a light anxiety feeling.

We see that the dream represents in fact, the occurrence of an earthquake. Recollections of the 
terrible catastrophe of Messina have had something to do with the excitation of the dream picture (recent factor-uppermost dream layer). On that occasion a village disappeared almost completely during the earthquake, in places the coast lines were altered. The dreamer had also read a few days before a novel by Ganghofer, entitled "Der Laufende Berg" (The Moving Mountain), which described how a hut sank deeper and deeper into the ground. We thus have, apparently, a simple reproduction of a newspaper account and of a scene described in a story and the fear might express the fear of earthquakes which so many persons showed when the Messina and San Francisco disasters were in the public eye.

If we could prove, with $S$ woboda, ${ }^{1}$ that the woman had read the novel twenty-eight days previously, or that some multiple of twenty-eight days passed since she read about the earthquake in the newspapers, we might quietly maintain that the dream was merely a periodic repetition of a strong impression received some time before. Admitting that this might be the case- what have we gained thereby towards the understanding of the dream?

We must really try to penetrate more deeply into the symbolism of the dream. The woman recalls that during an earthquake an island once made its

${ }^{2}$ Studien zur Grundlegung der Psychologie. A very interesting work in which the proof is brought forth that certain impressions are periodically given expression in the dream. 
appearance in midocean, in other words, - the earthquake gave birth to it. We suspect at once that the theme of the dream revolves around the bipolar contrast, birth and death, such contrasts being frequently represented in dreams through the same symbols. Let us look into that. Another association of ideas bring to the dreamer's mind the last Vienna earthquake. On that occasion a satirical wit played a joke and sent to the daily paper a scientific sounding but confusing account of the occurrence as coming from a specialist and ended his conglomeration with the remark: Meine Frau verspürte auch einige Stösse,-literally, "My wife, too, felt some 'shakings," "' but the newspaper editor, of course, changed that to "shakes." We are now coming a little closer to the meaning of the dream. A big tree which disappears, shakings, shakes, birth. What does it all mean? The answer is not difficult.

The whole dream assumes a different aspect. It represents an infantile scene from the earliest childhood, when the woman dreamer had observed the act of coitus between the parents. She had but heard the rhythmic motions of the bed. The quadrilateral space was the bedroom of her parents and the marital bed, which is also quadrilateral. ${ }^{2}$ The

2 In this sense of "vier-eckig," quadrangular, four-cornered, table stands for bed. Note the expression: ... "having left ... bed and board"; in German, literally, "table and bed" (Trennung von Tisch und Bett). 
further addition, "it was not a closed space-garden or Court?" serves partly as dream distortion, partly as overdetermination, a means of fusing room and bed. Just as two negatives result in an affirmative, the emphasis here (it was not closed) must be looked upon as an affirmation. Freud very properly states: "There is no negation in dream." If a . dream raises the positive contention: "My wife was not there"- the statement means the exact opposite, namely that the presence of the wife was painful and has to be covered up as much as possible.

We have here, then, the representation of a shaking motion of the bed (or a room). What has that to do with a tree sinking into water? The wellknown dream symbolism comes to our aid at this point. Water always stands for a reference to birth. $^{3}$ Children come from the water,- that is the first infantile theory of sex. Infants before birth float in water, we adults learn. And the tree? What does it signify other than the life-bestowing principle, the penis? Birth and death, both are represented through the penis.

The mother is here represented as the earth,-as mother earth. Changes in the "earth surface" is a symbolic reference to pregnancy (swelling of the abdomen).

Here we encounter a strange problem: the prob-

- A subsequent chapter will be devoted to a systematic account of birth dreams. 
lem of life and death in the dream. Is it not remarkable that contraries should carry the same meaning? For a further analysis of the dream reveals that it is a symbolization of death. We shall revert to that later.

Here I want merely to point out that a German scientist has studied this relationship long ago. In the peculiar, somewhat flowery language characteristic of his day, Schubert states: ${ }^{4}$

"What we find in the language of dreams, every tone of irony, every peculiar association of ideas and the spirit of prophecy, all that we find preeminently also in the original of the dream world, in nature. In fact, nature appears to be in concordance with our cryptic poet and to ridicule with him our pathetic joys and our joyful pathos, as when she mocks us in our graves at one time, wails in our ear when we are in the marital bed at another time, thus pairing in wonderful fashion pleasure and pain, joy and sadness,-like that nature voice, the air music of Ceylon which sings wonderfully joyful menuets in tones of harrowing, heartbreaking sadness. It is love time and joy time when the nightingale's wailing song is at its best, lamenting the rose over the grave, according to a poetic expression, and when all joyful notes in Nature have a wailing quality and reversely, a certain ephemeral bird is said always to celebrate its marriage on the grave, on the day of its death. Death and marriage, marriage and death, lie so closely associated in na-

Symbolism of Dreams, Leipzig, $\boldsymbol{F}$. A. Brockhaus, 1840. 
ture, as in dreams, often the one seems to signify the other, to conjure up or to imply the presence of the other; in nature's language they usually appear as ideas of equal weight, either of which may, on occasion, replace the other. As already observed elsewhere, the creation and the last dissolution of our bodies are processes everywhere in nature intimately related and identical with reference to the substances and changes involved; phosphorus is morning and evening star, alike, marriage and death candle at the same time, and while a portion of the continuously revolving cycle of metabolic processes is engaged in building up, another portion is engaged in tearing down. Pain and pleasure, pleasure and pain, are similarly related; the child of joy is born in pain; with the highest degree of sensory dysphoria and torture, even in the midst of fainting and apparent death, comes the supreme pleasure; reversely, too, sensory pleasure is a messenger of pain.

"That strange association seems not to have escaped the attention of the prehistoric race which has raised the phallus, or its colossal symbol, the pyramid, to mark the grave, and has celebrated the death divinity with ceremonials around the phallus; as if every act of a sensuous character contained also the raw indication of a deeper understanding. In the midst of the death ceremonials and mourning wails of the ancient mysteries there resounded also, as in some Shakespearian tragedy, the laughter over Baubo and Jacchus; back of the largely comical and joyful festivities there was often discernible a very earnest and tragic note" (Loc. cit., p. 38). 
We must look in our dream, too, for a deeper meaning. We discover a further sense to it: the dream is a death phantasy. She lies in the grave. A planted tree, such as she has seen in cemeteries, here sinks gradually into the earth. The four-cornered place in which she lies is the grave. ${ }^{5}$

As the earth spirit announces in Faust:

Geburt und Grab,

Ein ewiges Meer,

Ein rechselnd Weben,

Ein gliihend Leben.

She thus lies in the closed grave, in the cemetery, where flowers bloom (garden) and memorial trees are planted eventually to disappear.

On the great judgment day the graves open up and the dead awaken. Woe! How has she spent her life? Was it not a chain of sinful thoughts? Here we see the deep feeling of guilt, which must break forth at the end of the dream in the form of anxiety.

That does not yet exhaust the meaning of the dream. The most important feature is yet to be revealed. The fear at the end (anxiety) shows sup-

B "A woman dreams of going to visit a lady of her acquaintance who was really on her death bed at the time, following a prolonged illness; upon her arrival she is not a little surprised to find the woman in childbirth, a thing she cannot understand considering the sick woman's advanced age and her grown up son who was standing nearby. Here the incident of lying bedridden furnishes the associative link between childbirth and dying." (Das Leben des Traumes, by Karl Albort Scherner, Berlin. Verl. Heinr. Schindler, 1861, p. 147.) 
pressed sexuality; it reveals wishes which being unreachable, unfulfillable, and unsocial turn into anxiety. We discover that her husband, fearing the care and responsibility of children, has practiced for years coitus interruptus. That fear of pregnancy shows itself also in the dream picture. Also the fear that her husband, who is in fact a healthy and powerful man, may die suddenly, or prove untrue, etc. ${ }^{6}$

Here an association of ideas leads to the most important of the dream thoughts. She has a single child, a son, who is to marry during the next few months. On the evening before the dream her future daughter-in-law came to her and they planned the necessary bridal outfit. They inspected various waist models and the girl favored a shirt which buttons in front, saying: "That is very convenient. If I should have to nurse, I could use just that kind of a waist." She was surprised at the freedom with which the modern girl speaks of such things. As a girl she was entirely different. . . . She felt a momentary wave of aversion for the glowing, young, healthy girl who had robbed her of her son's heart.

Now we understand the third significance of the dream. The tree disappearing in the ground is

- The fear the man may die expresses her cryptic wish. The man is a prisoner and must not leave her for a moment alone. We can understand the motive: he must not go from her, that is, die. 
her son. ${ }^{7}$ She sees him during the bridal night (in her spirit), she sees anticipatively her daughter-inlaw's pregnancy. She is jealous and that jealousy causes her keen suffering. The little son, whose nurse she had been, in the dream is often represented as the penis. Here he symbolizes both. The dream means, therefore: I foresee the end of my love! My son will marry soon. He will gradually wean himself away from me. I mean less and less to him. $\mathrm{He}$ is becoming entirely absorbed in his love (the sinking tree). He will render his wife pregnant, he will be a father. That is how times bring on changes.

It would be very interesting to find out what the continuation of the dream indicates. How she frees herself of these difficulties. That, of course, is the chief theme of the dream and therefore it is completely hidden from view.

But from analogy with similar previous dreams of this patient-we are dealing with such a onewe may infer that the missing part deals with the death of the young rival. Such a rival once died off-that was four years ago-and because of the reproaches which she felt unconsciously over it, her neurosis developed. Now her phantasies play with the same thought and the feeling of guilt reacts with the expatiation of anxiety.

"She "planted" it, raised it, took care of it. The tree, 1.e., son, must be her support. 
(.) The anxiety in the last analysis is fear of self. ${ }^{8}$

The most important thought, in this connection, is the one most deeply hidden. It is the thought of death. Rather than not begrudge her own beloved son to her future daughter-in-law, she would see him dead. He should die, he should be out of the way. A grave is dug and a body is laid in. That is for her the most important change in the earth surface.

Such evil thoughts encounter inhibition and become expressed as anxiety. For she truly loves her son. She does not want to lose him.

In every dream the thought of death is also woven in.

There is no dream which does not contain an. adumbration of death.

Our woman patient lives only with the dead. She is rich in spirits (play of words, a pun on: geistreich, spiritual).

Further associations of this dream lead to thoughts of masturbation (shaking motions) and bisexuality. ${ }^{9}$ But it might confuse the reader to go on. The dream has already become complicated. But there are no simple dreams.

- $C f$. the words of Richard III about the terrible dream before the battle.

"The so-called "maternal body phantasy," i.e., the illusion of being within the body (coffin) of the mother and of watching the details of marital experience, too, comes here to surface. She is afraid of "being buried alive." 


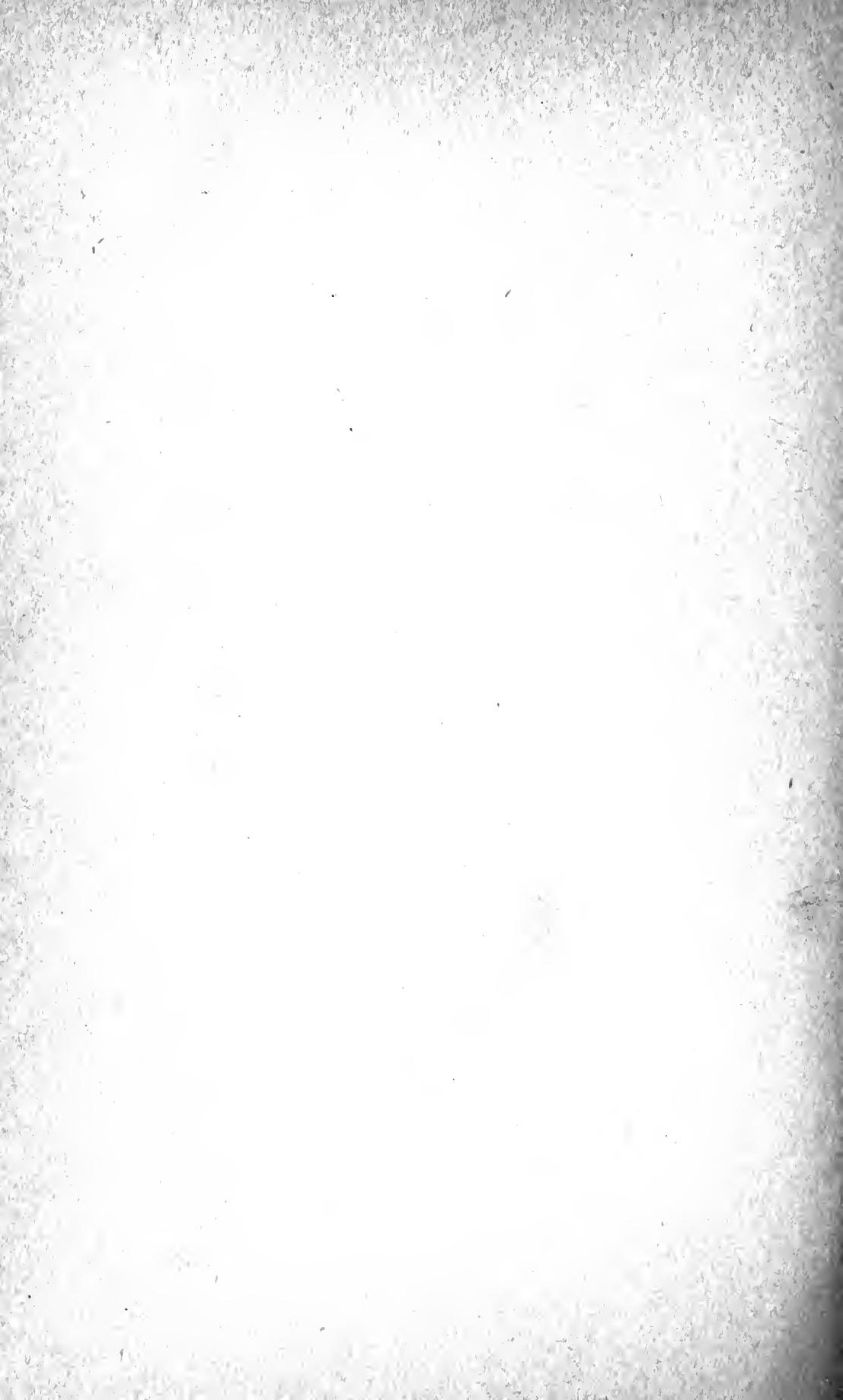




\section{V}

DREAM MASKS-PURSUTT DREAMS-THE POLJTICAL DREAM ABOUT BISMARCK-THE WONDERFUL VHLA-THE DREAM ABOUT THE BAKER-CONTRARY MEANING OF ABORIGINAL WORDS-THE PSYCHOLOGY OF THE DON JUAN TYPE-SAVINGS BANKBOOK AND LOVE-EVIL THOUGHTS OF CHILDHOOD-THE SKILLFUL FENCER-THE DARK MAN, A SYMBOL FOR DEATH 
Glaubt mir, des Menschen wahrster Wahn Wird ihm im Traume aufgetan.

[Believe me, man sees his roildest fancy come true, in his dreams.]

Richard Wagner 


\section{V}

Numerous examples have shown us that the dream speaks a symbolic language and that the unraveling of the symbols yields a partial explanation of the dream. I must underscore again, a partial explanation only, because in addition to the symbolism various processes involved in the dream distortion play a rôle to which I must next call attention.

One of the most important forms of dream distortion is the transposition into the antithetical. The oldest dream interpreters were already aware of that process and the popular mind has also perceived the truth. If one dreamed of death, the Egyptian dream book explained it as meaning birth; if one met great misfortune in dreams the ancient interpreters took that to mean the presaging of good luck. These popular attempts at interpretation have been treated with ridicule by some of our scientists; but it appears, as Freud rightly remarks, that the folk mind was nearer the truth in these matters than the learned scientist. Many dreams may be interpreted as signifying an antithetical transposition of material. "Excrement means gold. Gold and excrement are antithetical, that is why the 
devil's gold turns into excrement. But is it a peculiarity of dreams to represent objects by their contraries. Thus, it means illness when one is in full dress, quarrel when one makes love, and keen sensu-. ous pleasure in dreams not infrequently is a forerunner of actual pain: vae tibi ridenti, quia mox post gaudia flebis." (Kleinpaul, Sprache ohne Worte.)

I record now the most instructive example that has come to my attention. A woman said to me: "Dreams are nonsense!" For the fourth time I have had the following ridiculous dream:

(27) A little, old, ugly woman chases me around the table; I am afraid and roake up with fear.

The meaning is very simple. If we translate the little old ugly woman into the opposite we find that in the dream she is being pursued around the table by a big, attractive young man, an experience which corresponds to a wish on the part of this attractive woman who is married to a very weak, delicate man, and a wish which through repression (on account of its "forbidden" character) is turned into a fear. The continuation of the dream is recalled by the woman only after my interpretation and corroborates the interpretation. The alleged old woman in the dream tears off the subject's blouse and wants to stick her hand between the breasts a procedure wholly illogical on the part of an old woman but perfectly intelligible on the part of a young man in the same situation, which really 
depicts a rape phantasy. On the other hand, it is also conceivable that the picture represents a reverse act, that she struggles with a wish to run after a big man; but the end seems to make that illogical. Why should she want to tear open the man's waistcoat? Here we learn another dream process, the so-called transposition from below. In many dreams what takes place below is represented above and reversely. That is an extraordinarily common form of dream distortion, a process which, moreover, plays also a tremendous rôle in the symptomatology of the neuroses. Applying the principle of transposition from below above we arrive at the wish to act aggressively and tear apart a man's trousers. Both interpretations, the aggressive and the defensive, fit into one another very well; for there is no sadist who is not also a masochist, no exhibitionist who is not a voyeur at the same time. - "All instincts appear in pairs." 1 Thus nature herself upholds the law of opposites. The dream must bear a meaning also in a positive sense. She fears the mother. She has homosexual leanings and wishes the assault which, moreover, signifies a question about her motherhood.

${ }^{1}$ Alfred Adler, Der Aggressionstrieb im Leben und in der Neurose, Fortschritte der Medizin, 1908, No. 19: "In the healthy, the perverse, and the neurotics, alike, the motive power is generated by two originally disparate instincts which are later drawn together and, as a consequence, the sadistic-masochistic manifestation corresponds, alike, to two instincts,-the sexual instinct and the instinct of aggression (Aggressionstrieb)." 
For the woman is sterile. She will never have milk in her breast. And now we arrive at the most significant meaning. She wishes to be again with the mother and lie at the nurse's breast. The grip on the breasts is the first pleasurable contact of infancy.

The dream thus plays upon various motives. More than that! The old roman who seizes her at the heart is the symbol of death. An ancient symbol. Every fear is also a fear of death. In fact, in roundabout ways,- -always the fear of death!

Thus we see an interplay of the yearning for life and the fear of death, the fear of living and the yearning after death, commingled.

Moreover, these forms of dream distortion are supported by linguistic characteristics.

Linguists have pointed out that in man's aboriginal language many words had double meaning, signifying one concept and at the same time the exact opposite.

This feature of language was known already to Schubert, who in his Symbolik des Traumes (Symbolism of Dream) maintains :

"Recent, more penetrating linguistic investigations has proven everywhere the prevalence of interchangeable terms in the articulated language and the kinship of words. First we frequently find that words having contrary meanings originate from the same root; as if, in expressing itself, the soul emphasized the inner organic double sense, rather than 
some external particularized manifestation thereof. ... Words designating warm and cold are not only similarly sounding in some modern languages: for instance, Italian caldo, English cold, and German kalt, meaning the opposite; but within the realm of the same language we find words for warm and for cold derived from the same root (gelu, gelidus, cold; and caelo, calidus, warm); and the God of the tropical South has descended from the cold North. Just as frequently in myth and language the good divinity is fused with the evil one and reversely, the evil divinity is taken for good, so in Persian, although the corresponding myth makes a strong division between the two principles, the name of the evil Ahriman and that of the god of light, Orim-Asdes, both come from the same root; so also "épos (eros), love, and "ép (eris, quarrel; and in various other languages the words for unity and union and enemy and division are the same. (Sreedenborg elaborated a theory that sensuous love generates in heaven the crassest hatred.) Light, too, the symbol of truth, and falsehood, or lying, in some languages are derived from the same root, because light (the beautiful morning star, as it is called somewhere, after flaring up in a scorching flame, becomes the rapacious wolf, the evil Loghe, who elsewhere appears also as dog and bitch, in unpleasant connotations. That double quality (scorching and lighting) of light is played upon in the jargon of myth everywhere. Blood, too, appears in double sense, as poison, anger, raging madness, and as expatiation, appeasement, peace. Rage and meekness, darkness and light, the heavy metal and the light bird, air and iron, the generating of joy 
and sadness, low and high, sensuality and impotence, and many other concepts of similar antithetical character are traceable likewise to the same roots; the lamb as well as the beast, which are often met as symbols of the creative logos first appear as ram expressing the generative principle, then as representing the grossest sensualism (here, too, lamb and flame, from same root); or as snake either in a beneficial or in a fearfully evil sense."

Not infrequently we are in a position to trace in a remarkable manner precisely how words came to be used in a sense exactly contrary to their original meaning. A few examples will suffice. The kinship of knowing and generating has been traced already in a very remarkable manner by Franz Baeder: "In language and myth, dove, too, which as the holy spirit puts in motion the water of life as well as man's cognitive spirit, is identical with the bird phonix and with the palm (tree or leaf). The palm, also the flower of night at the fountain of life, or, in other versions of myth, the acorn, vine, or fig tree becomes the tree of knowledge, which is at the same time also the tree of contention. Finally the tree of knowledge becomes the lingam, the apparatus and symbol of sensuous delights. In the same manner the seeing eye, the fountain of light, the Word, becomes on the one side the building, creating hand, on the other, with the hand itself, signifies the organ of physical generation. The 
vitalizing eye becomes at the same time the evil (killing) eye, the truth-generating, oath-yielding hand, the organ of falsehood, lying, waste. Thus, that young prudish virgin who in the myth was never touched by the breath of a sensuous wish becomes the sophisticated goddess of the most unrestrained and wildest sensuality; the creative, spiritually cognitive, word undergoes a terrible change under the picture of the horrible ram Mendes, whose cult includes all the shameful deeds relating to the most bestial animal lust; the fish and the snake of sensuous indulgence generate also that terrible poison, which has corrupted the world and life. The word of love, the holy name, the law become punishment, anger, revenge. Just as linguistic catastrophes change good into evil, light into darkness, so the same mechanisms effect the reverse transformations, evil turning into good; and many èxamples in myth and language, show evil and poison transformed into lovely figures or beneficial agencies."

Freud, in the şecond volume of the Jahrbuch für psychoanalytische und psychopathologische Forschungen, called our attention to a pamphlet by Karl Abel, entitled Ueber den Gegensinn der Urworte ( $O n$ the Contrary Meaning of Aboriginal Words, published in 1889).

In that work Abel points out:

"In the Egyptian language... that unique relic of a primitive world, there are a fairly large 
number of words with double meaning, each the exact contrary of the other. Consider the apparent nonsense of having to bear in mind that the word strong, for instance, in our language, means strong and weak at the same time; that the noun light means light as well as darkness; etc., and there we have a concrete picture of what the Egyptians were accustomed to meet in their daily language. Who can be blamed for an inclination to shake one's head incredulously? ...

"Considering this and many similar instances of antithetical meaning, there can be no doubt that there was at least one language containing a multitude of words signifying one thing and at the same time the exact opposite. Strange as it may seem the fact is plain and we must take it into consideration.

"Among all the eccentricities of the Egyptian lexicon the most extraordinary perhaps is the fact that, in addition to words which cover opposite meanings, the language contains also compound words, formed of a couple of syllables of contrary meaning, but standing as a unit the meaning of which disregards entirely the sense of one of the component parts. In that remarkable language there are, thus, not merely words which signify strong as well as reak, commanding as well obeying; there are also composite terms such as old-young, distantnear, uniting-dividing, outside-inside, which in spite of their double and antithetical source, signify, respectively, old, distant, uniting, outside. . . These compound words deliberately bring together contrary meanings, not for the purpose of forming a new meaning, as is done occasionally in the Chinese 
language, but merely in order to use the composite term in the sense of one of its antithetical components, when the latter would have carried the same meaning, if taken by itself. ...."

But the riddle is more easily solved than may appear on the surface. Our concepts arise through contrasts. "If it were always light," states Freud, in his interpretative abstract of Abel's essay mentioned above, "we should not distinguish between light and darkness, and consequently we would have neither the concept nor the word light. . . . It is clear, everything on this planet is relative and has independent existence only insofar as it stands in relation to, and differs from, other objects. ... Since every concept is thus the twin of its opposite, how could it be perceived, how could it be communicated at all to another trying to acquire it, except through comparison or contrast with its opposite?"

In dreams this contrast or antithesis plays a great rôle. The most wonderful peculiarity of human nature, man's bipolarity, expresses itself through this extremely interesting psychic phenomenon. There is no "negative" in dreams, as Freud aptly remarks. But in that sense there is also no "yes." The dream divinity is the arch-type of the doubter.

In some dreams this contrariness is deliberately expressed, and specifically through doubt, as in the following dream of an artist suffering of a professional neurosis: 
(28) I am running away from some one, or else I am pursuing somebody through water, over steps, into the room. It occurs to him that there was some one else in the dream; we try to inform ourselves who that could be, and he replies it was a colleague, a piano player like himself, who tried to enter the technical school; he was not accepted and that worried him very much.

The person he pursued he does not recall, but we know from previous analyses that it can be only his own mother, and in fact it was his habit as a child to run off over the steps and into the room when she threatened to punish him. He remembers such scenes, he recalls also that during the previous year he and his mother bathed together in a river. The men's dressing cabins were on one side, the women's on the other. In spite of the great distance he swam nearly one half hour to his mother, whom he reached in a state of exhaustion. We see that both incidents are fixed in the dream. As a child he ran from his mother, as an adult he swam across the river to her side. What is the meaning of this dream? He is a great Don Juan, mostly in his phantasy; but if he followed his inclination, he would become the kind of character called in Vienna a Steiger (literally, a "stepper"). Hence the mean- ing of Stiege (steps, or stairway). The rooms, as usual in dreams, signify women (in German, Zimmer-Frauenzimmer, rooms-women); to climb after 
Frauenzimmer (women)-that is, indeed, his chief preoccupation. He runs after all women, one after another, and cannot be true to any one. But why does he run after all women without being true to one? Because he is running away from one woman who cannot be a wife to him-his mother.

This brief dream discloses the psychology of the Don Juan. Because of his perpetual fidelity Don Juan is untrue. He is eternally true to his infantile ideal, the mother, and because he looks everywhere for this ideal, and never finds her, every woman rouses him and promptly disappoints him. What interests him in the end is the woman's resistance and, sure of disappointment, he concentrates his whole attention on the task of overcoming the resistance and of making the conquest. The two opposite tendencies, the running off, which implies pursuit, or, if we prefer, the pursuit, which similarly designates a running away are strikingly well expressed in this dream. Dreams of water are usually birth dreams and it was not an accident, therefore, that in this case the dream evoked the recollection of the dreamer's swimming to his mother. But who is the colleague who was not accepted? His younger brother. He wishes to be the only child in his mother's "technical school." That the master is the father, even the tyro in analysis will have surmised. Mr. $\mathrm{X}$. is also the father (condensation) who thus appears excluded from the 
- school, like the brother. Piano playing is a common symbol for "sexual intercourse" or for "masturbation," like all other acts involving the notion of "playing."

I continue this series of dreams by giving next a very interesting dream in which transposition plays a great rôle. This is a so-called political dream. Indeed, dream life conceives nothing as holy. The greatest and loftiest personages of the world of high politics are utilized by the dream as symbols for commonplace homely thoughts. But let us not anticipate the interpretation but relate first the dream, which on first perusal gives the impression of something logical, and that is seldom the case with dreams. My political dream is as follows :

(29) I am in the Hofburg and see Bismarck. With others I shout: Hoch! Some one starts the anthem. I join lustily. Several fall on their knees. ...I see Bismarck again. We speak about the incident, also about the books which he carries. I tell him that our library showes a striking gap whenever we take out a few books on a journey. He thinks he never had that feeling, and I explain that by the fact that in his tremendously large library a few books more or less makes no difference.

We have here a political dream, in which some German nationalists persistently acclaim Bismarck; they become noisy and partly as reaction call forth 
the answer of all good patriots, the people's hymn. And yet! Like most political dreams this dream, too, has nothing to do with politics.

I had the dream in P., a beautiful rural place at the sea. We had our summer place there. But unfortunately my vacation was disturbed. One week before the projected removal to the place I received disquieting news from $F$., where my aged mother lives. A telegram called me to her. I found her in a serious condition which required my constant presence near her. Under such circumstances vacationing at $\mathbf{P}$. was out of question. I determined quickly to remove my family from $P$. to Abbazia, where I could see also my mother daily. I also thought that the presence of my family would bring joy to the bedridden patient and aid her recovery. (That actually was the case. There is no physician like joy.) I remained for a few days at $F$., until her condition improved somewhat, and then went to P., which I was sorry to have to leave. On the second night of my sojourn there I had my "political" dream.

And now the analysis.

$I$ am in the Hofburg. My summer residence pleased me immensely. It was a villa with a long veranda permitting a beautiful view across MariaWorth. Everything was so pleasant and comfortable, that my little one said: "The Kaiser could not have it any nicer!" Hofburg, then, means the best 
summer residence. A further association is the name of the owner. His name is Schweinburg. He is the architect who has built the Burg theater at Vienna, which some one called jestingly the Schweinburg theater. The Hofburg of my dream, then, is my villa, and the beginning of the dream signifies: $I$ am at $P$., in my fine, beautifully situated summer residence.

And I see Bismarck. What has Bismarck to do with P.? That is also easy to understand. The Bismarck of the dream was a strikingly tall, thin man with yellowish-muddy complexion and white mustache. The dream here carries out the witticism so common in dreams, of covering up the content by transposition into the opposite. The big, lean man with white mustache and yellowish complexion is a small, heavy, florid appearing man with a dark mustache, my friend Dr. M., whose summer residence in $P$. so pleased me the year before that I chose one in the same place. Dr. M. had an unpleasant controversy with a society to which we both belonged and he adjusted it with such diplomatic skill that $\mathbf{I}$ assured him at the time: Bismarck himself could not have done better! Moreover, another colleague told me of Dr. M. that he was very clever and experienced, a second Bismarck in his vocation. The dream represents the wish that he should now act as skillfully as a Bismarck and help me 
get released of the contract for the summer residence without too great a loss, so that I may be able to return quickly to mother.

With the others I shouted: Hoch! We are a group all praising $\mathbf{P}$. We love the beautiful place at the sea, the clean roads. Whither one walks one has the impression of moving in a great garden; there are interesting excursion spots; we praise the bathing, the charming position of the establishment, etc.

Some one begins the people's anthem. Mr. S., a man of the people, now well-to-do, thought the place was very expensive. He has spent a lot of money in a few weeks.

I join lustily. That is a fact. The absence of a moderate priced inn might interfere with my stay at $\mathbf{P}$.

Several persons fall on their knees: refers to the ridiculous deference of some persons towards the proprietor of the establishment.

Then I see Bismarck again, we speak of the incident. Incident is an important word. Ein Wechsel der den Zug auf andere Geleise bringt: a change which makes for a different turn. It is the illness which causes painful experience to a being most dear to me. But that will carry us into another channel of our dream thoughts. Let us beware of digressing and continue the interpretation on the 
path on which we have already started. I spoke with Dr. M. about my difficulty and he promised me his assistance in canceling the contract.

... Also about the books which he carries. I tell him that our library shows a marked gap whenever we take out a ferw books on a journey. He thinks he never had that feeling, and I explain that by the fact that, in his tremendous large library, a few books more or less make no difference.

This is a reference to the savings bank account on which I drew before undertaking the journey. My wife, always the economical, thrifty influence in our household, thought that the summer expense -I had at first intended to spend six weeks in the country-would cause a marked gap in our modest resources. Dr. M., who was also to stay six weeks at the place, is well-to-do and can more easily afford the luxury. The dream plays upon this thought. In fact, I had spoken to Dr. M. about the vacation expenses. ${ }^{2}$

We have interpreted the dream thus far. It contains to a certain extent regrets that $I$ had chosen so expensive a summer resort. It is, as if $I$ had said

'Savings bank account here means also woman. In my monograph, Keuschheit und Gesundheit (Prudery and Health) I have stated: "There is no savings box for the spermatozoa." Dr. M. figures as an admirer of the fair sex. I accuse him of maintaining a harem, while I have but one wife. According to the "symbolic parallelism" of which we shall speak at length in the next chapter', "spermatic fluid" means also "money." (Consider also the expression "striking gap" and "tremendous large library," from that standpoint.) 
to Dr. M. in the dream: "Yes, you can afford to live at the Hofburg. What does it matter if you do make some inroads into your savings bank account? I am a man of the people, for whom a simple country place would be good enough.

But let us investigate further. I have already mentioned that the word Vorfall, "incident," refers to the change leading in another direction. Let us now take up the other path. ...

There are a number of dream symbols almost regularly permitting a particular translation. A symbol of that type is also the Emperor in the dream, who, as I have already said, usually represents the father. Applying that key, the Hofburg becomes my father's residence and Bismarck is my mother. That fits even better. A strikingly tall, thin manstands antithetically for a small, heavy woman, like my mother, whom father always called his Bismarck. Wisdom is her most striking characteristic. The yellowish complexion due to illness also corresponds. I found my mother very ill and I was distressed to see her face drawn and distorted with pain. Bismarck, thus, represents two persons, a process called Verdichtung (condensation), by Freud.

I join other persons shouting, Hoch! We wish her a speedy recovery. "Kopf hoch-Mütterchen, -keep up your courage, mother dear,-you will get better," I told the dear aged patient when she began talking about a will and about dying. Some 
one starts the anthem: It goes: Gott erhalte-Gott beschütze-God keep,-God protect"-in this case, of course, mother!

Several persons fall on their knees: that refers to an actual occurrence at the meeting.

We speak of the occurrence: that reproduces a daily experience. ... Also about the books he carries along, etc.: gives the solution to the dream. I confessed to mother that I made a great sacrifice with the journey (savings bank account). She spoke about the distribution of her jewelry which we cherish not for its monetary value but on account of its associations.

But in my dream I see mother as an immensely wealthy woman possessing a tremendously large "library." The wish fulfillment is clear. We, her children, are the heirs. Instead of relics we receive tremendous sums of money, for she is as rich as a Princess (Bismarck). The dream reveals to me an ugly, unpleasant, painful thought, which I have never entertained in waking life, but which must have been slumbering in my breast. While mother was speaking about the distribution of her humble goods, I must have repressed an emotion which, expressed in words, may sound approximately as follows: "Why are you talking about your pitiful possessions, as if you were leaving behind, who knows what great and valuable inheritance! You won't even cover the expenses of my journey here." 
I need hardly emphasize that my waking consciousness is unaware of such a thought. I am anything but careful in money matters and I am extremely sensitive. But such unconscious thoughts are linked with the most delicate feelings in good men, a fact which should make us more thoughtful about all those persons whom we are disposed to consider as "bad" without knowing more closely their circumstances.

The analysis thus far has not shown the relationship of the dream to the infantile root. But the connection is there. It reminds me of one of the most unpleasant experiences of my childhood. I was a small boy and was standing in front of the library, which a brother's pride and mine had built up (the brother was six years older). Suddenly the thought came to me: "If your brother should die now, this library would be wholly yours!" I ran away shocked. I thought I was a terrible sinner, and the recollection of this occurrence has often caused my cheeks to flush with shame. (Sudermann relates a similar experience in his novel, Die Geschreister.) I believe that I also struggled at the time with the temptation of stealing some of the books and selling them to the second hand dealer, a thing I often did with my own books.

The pretty political dream thus has also a deeper meaning-motivation. My mother is wealthy. But I am the only heir. My brother does not enter into 
the situation. The boy's selfish wish has still retained the power of influencing the plastic pictures of the dream (library).

Three weeks later in Abbazia I had a dream which was a continuation of the former. A proof that the dream thoughts play variants on the same theme.

(30) I am in Neurwaldegg. One of the last houses is a wonderful villa belonging to my mother. I ascend a marble stairway and come into a gigantic reception room exquisitely furnished in red and gold. "Oh," I say, "there is comfortable space for everybody here."

The history of the preliminary circumstances of the dream is partly known. I rented a residence at Abbazia where we were in fact rather cramped for space. I also secured for mother a room which seemed to me not well enough furnished. In the dream $I$ am again in Vienna. One cannot be more comfortable than traveling to Neuwaldegg, a suburb of Vienna, instead of traveling to distant Abbazia. My mother is a wealthy lady. In her reception room we are comfortable. Here the continuation of the dream comes to my mind:

$W$. wants to give our servant a krone as a tip, but the latter scornfully disregards the gift. ${ }^{3}$

- Further determination reveals hidden thoughts, a longing for the return to the mother-body, where there is "comfortable room for all" (?). The tip or gratuity, in German, "Trinkgeld," literally "drink-money," leads back to wet-nurse memories. 
On the previous day I had lost a crown playing the game of Tarok with $W$. That very night even our servant refuses that sum as a gratuity. The dream speaks volumes. ...

This dream, like the other, lends itself, of course, to a deeper analysis. But I must forego the task. As it is, I have already disclosed about myself much of what most persons prefer to keep hidden.

The Dream about the Confectioner:

(31) I am on the street. A big-no, a middlesized, rather diminutive man, with a black mustache pointing dorenreards, hold me by the hand and does not want to let go. He wants to squeeze me. I say: let me off, or I'll call the policeman standing there, near my children. But he still squeezes me. I shout loudly: police, police. The officer does not hear my outcry. The man squeezes me harder. I struggle this way and that and I shake the hand so hard that the man's squeezing does not hurt me. Meanwhile I shout again: Police, police! The officer sees us and comes running in our direction. The man is arrested (?). Suddenly we find ourselves in the Liliengasse (street). I and my two children in the room, and in the kitchen the dark man who now wears a big black beard. A small hallway between us. The man's name is Pellmann and his remarkable memory has made an impression in the Court. I cannot shut the doors. While he is outside I try to lock up. But he comes into my room from be- 
hind. I say to him, laughingly: "Of course, I can't do anything rith so good a gymnast." He looks like Socrates-the "Sturmgeselle."

A strange, nonsensical dream. Let us penetrate into the gist of the dream thought and take apart the warp and woof of its structure.

The dream is linked to two occurrences of the previous day.

R. told me that he has looked up the Egyptian dream book because he has found therein many resemblances to Pellmann's system of memory culture; at a restaurant I saw an illustration of Sudermann's "Sokrates der Sturmgeselle"; also a satirical picture: Sudermann takes up the warfare against critics. So much for the recent inciters. Now we begin the analysis.

I am on the street. This brings to my mind the Landesgerichtsstrasse and the spot where the action takes place in the little park in front of the Czernin palace, where the Czernin gallery is situated. The road leads from my house directly past there and to the Secession Building (an art gallery). In the Czernin gallery I learned to appreciate the art of painting. I recall particularly an incident with Professor E. We were standing in front of the painting of Paulus Puter,-no, it should be Potter. My companion exclaimed: this picture has Luft, Luft, Luft, - atmosphere! (literally, air!). $A$ big-no, a middle-sized, rather diminutive man, 
with a black mustache pointing downreards holds me by the hand and does not want to let go. This brings to my mind, Mr. Rummel, confectioner in my old home town, whom I have seen only a few times, the last time some fifteen years ago. This fellow Rummel had once written a rather shallow feuilleton under the pseudonym Lemur (a transposition of Rummel) which stirred me to an imitation of Lessing's verse:

Wer wird nicht einen Lemur lesen-

Doch wird ihn jemand loben? Nein.

Wir wollen weniger gelesen

Und mehr belobet sein.-

[Who would not read a LemurBut will any one praise him? No. We would rather be less read And better liked.]

What is the meaning of a big, no, a middle-sized, rather diminutive man? Clearly a person who fuses all these qualities, in the present case, I myself. Perhaps I imagine I am a big,- - no, a middle-sized investigator when in truth $I$ am rather a small one. Now I understand the "confectioner." I put my "sugar wares" before my readers, like Mr. Rummel, feuilletonist and confectioner. In fact I was busy with my book on the evening before the dream. I feared it was not "deep" enough, only "Zucker- 
werk," confectionery tidbits. I decided to cast off these sweets, these "bonbons," as a colleague once called them. And now the next passage:

He does not want to let me go. He roants to squeeze me (i.e., keep down the level of my achievements). The watchman who stands by my children is a watchwoman, namely my wife, who takes a keen interest in my work and is not easily satisfied. She must help me-get that "Rummel" off my breast.

The ratchman does not hear my outcry. My wife in my opinion does not pay sufficient attention to my writings.

I struggle this way and that way and I shake the hand so vigorously that the squeezing does not hurt me. I cover up my superficiality, I get along well that way,-earn money; Professor E. and Professor F. warmly shake my hand. I got along well. I know now something about oil paintings, I won't mistake a print for an oil painting.

The man is arrested: That leads to an overstressing of the dream picture, an overdetermination and the analysis of this point would carry us too far afield.

Very interesting is the recall error Puter instead of Potter. In the forgotten dialect of childhood "Puter" means being rid of, that is, free. This first part of the dream, then, portrays the desire to get rid of the petty confectionery tidbits with the aid of the wife and of Professors E. and F. 
Suddenly we find ourselves in $\mathrm{Cz}$. The dream, like every, dream, stretches its roots down into the infantile life. I and my two children in the room and in the kitchen the dark man who now wears a big black beard. I have now reached a step higher; for I seem myself in the dream. I am a Pellmann possessing a wonderful memory. For days I have been thinking over a plan to write on the subject of memory.

His remarkable memory has made an impression before the Court. A roundabout self-praise. I think a great deal of my last appearance as expert at Court, where my testimony engaged the closest attention of those present. Now Pellmann is changed into Sudermann who takes up the cudgels against critics. I wish to get rid of my self-criticism. I am Socrates who is also "a drawer of water and hewer of wood"; Socrates criticizes the latter. The criticism openly resented is felt in a roundabout way.

So skillful a gymnast can't be kept down: It brings to my mind the nursery room of $K$., in the watchtower, connected by a subterranean passage with the gymnasium room, so that the children should not catch cold during inclement weather. I am the gymnast and the dream reassures me that $\mathbf{I}$ shall free myself of all unpleasantnesses in life, that I will find my way out of all difficulties. Irrational dreams of greatness about my forthcoming book! 
Infantile, vague sexual reminiscences! Unpleasant experiences of the last few years! Doubts concerning my personal ability! Endless self-adulation! Disregard of all criticism! All that condensed, fused in a single web! Here we see how richly the dream is determined. Not only two, or three or four strands,- any number of them may be fused in the dream. Moreover, how well suited is the choice of Rummel, the feuilletonist, the confectioner!

The analysis thus far does not include the most important features. Who holds me down to the affliction of my unconscious? Naturally my wife. I feel myself held down by the marriage tie. The wife and the two children are a stumblingblock against carrying out the polygamic instincts. I wish to be Socrates and at the same time to enjoy the adventurous "storm and stress" life.

Another feature is noteworthy. Why does a big dark man play here a rôle? That brings to my mind a strikingly handsome colleague with whom I have practiced gymnastics. Clearly homosexual leanings are breaking through in the dream,-leanings against which my wife must protect me, for they may land one in Court! That is why he steals into my room from behind. In the dream all caution and all watchfulness proves useless.

Here the anal complex links itself. That was to be suspected already with the recall of the association,-Luft, Luft, Luft! atmosphere,-that is, air! 
I have reached thus far without doubling on the trail of associations. Now it occurs to me that the pseudonym Lemur is the reverse of Rummel. That suggests a return to the great dark man. And, lo! Presently I am thinking of a little blonde girl, Bertha. My first love! On the very day when the Lemur feuilleton had appeared, I saw her standing in front of the confectioner's shop window, my hero of the day, and I suddenly fell in love with her. One can imagine the excitement of a high school boy who produces lyrics by the ream and who is finally lucky enough to have an unfortunate love affaira love unrequited. That first love truly was an unhappy one. I never spoke to the lady of my heart! But she once turned around to tell me that she finds my everlasting dogging her steps foolish. ...

Nevertheless I remained faithful to her for years. Indeed, perhaps I have never outgrown that first love. There was a sweet sorrow to my passion. The squeezing did not hurt me in the dream, although she did not let go of my hand. Note the wish fulfillment. She grabs me and does not let me off. She holds on to me.

Now I understand the cryptic hatred which the dream discloses against my wife. I revenge myself on women for the scornful rejection I experienced on the occasion of my unforgettable first love affair. This process is illustrated also in the psychology of the Don Juan type (in addition to the features al- 
ready mentioned). Only in that sense can I understand the contrast between my conscious and my unconscious attitude towards my wife. I say to myself repeatedly: if you were now once more free to choose, you would again choose your wife. That, of course, is the highest compliment that can be paid to a woman.

In the unconscious I see myself back in the Liliengasse without her. There is where I lived when I fell so passionately in love. The watchman is by antithesis (of the imperative: watch out!) the command: sleep on, wife! That seems to me to be very strongly indicated. For I am (without the wife) at home in $\mathrm{Cz}$. with my two children, with my first love and with my mother. Truly a remarkable loyalty ("astonishing memory"). Pellmann reminds me of a psychiatrist by that name, who wrote an interesting book and of Pekelmann, a boyhood friend. He was a diminutive fellow-an actor of medium ("middle-sized") quality and an excellent genial reciter. (Observe the association series: Stekel - ekelhafter - Mann - Pekelmann - Pellmann.) My friend repeatedly recited a ballad by Meissner called The Jewess, and ending with the refrain, "Her grave-it waits."

The dark man is death. When considering systematically the subject of death symbolism I shall take the opportunity of speaking at greater length 
about the "black man." Death wants me. I refer him to my wife who, through association with Socrates, receives the uncomplimentary and undeserved appellation of a Xantippe. Death cannot harm me. I do not fear death and never feared it.

I am Socrates, draining with philosophic calm the hemlock cup. Now it strikes me that the great Turner whose picture occurs in the dream was really Richter (Also it brings to my mind a gigantic and powerful school colleague, who is already dead.) The associations Landesgerichtsstrasse, Wachmann, Richter (Court Street, officer, Judge) lead into the criminal realm. The laughter at the end of the dream, too, is to be understood in reverse sense. It is a sad dream with depressing thoughts. Pellmann is the criminal against whom I shut the door to my heart.

Now associations overwhelm me. The deepest layers of the dream are ready to break to surface. But we must abandon the analysis at this point. Let us emphasize first the fact that the dark man is a composite picture of a number of persons. They are: Rummel, Bertha, Richter, Pellmann, Pekelmann, death, and, finally, my own inferiority. All the persons of the dream are divisions of my selfhood and vitalized with my thoughts. The process of condensation depends on the capacity of the psyche of identifying itself with various persons. Further 
illustrations of that process will be found in the following chapters. Here I only want to point out that this dream, too, has a pronounced bisexual character and is a proof of "psychic hermaphroditism." 


\section{VI}

DREAM MASKS, CONT. - TRANSPOSITION FROM BELOW, UPWARDS, AND FROM THE FRONT, BACKWARDS-SCORN UNDER THE MASK OF GENTILITY -A DREAM WHICH MUST BE INTERPRETED IN REVERSE SENSE-THE SECOND SYMBOLIC EQUATION-THE SYMBOLIZATION OF SCORNFUL LOVEWHY THE CHILD CALIS "PAPA!"-A BIOGRAPHIC DREAM 
Es ist mit dem Menschen wie mit dem Baum. Je mehr er in die Höhe und Helle will, um so stärker streben seine Wurzeln erdroärts, abrö̈rts, ins dunkle, Tiefe,-ins Böse.

[Man is like a tree; the more he strives upwards and towards the light, the stronger his roots drag him doronwards, earthwards, into darkness and the abyss, -into the pit of evil.]

Nietzsche 


\section{VI}

The principle of "transposition into the opposite" is carried out in various ways in the dream. A preferable means for the substitution is the displacement from below. Anything referring to the bodily region below the umbilicus, morally abhorrent, may be transposed to the upper part. Thus, the mouth may represent the vagina. Here we encounter the first symbolic parallel (Gleichung). These symbolic parallels are a great aid to any one who knows them, at times indispensable in the interpretation of dreams. The parallelism reads: All bodily openings (in the dream) are equal to each other and may substitute one another. Thus, mouth, eyes, ears, nasal opening, anus, vagina, urethra and navel ${ }^{1}$ may substitute each other.

An example will illustrate this principle of symbolic parallelism. A girl dreams:

(32). Mama has told me not to allow so much boring in the nose,

${ }^{1}$ Nabeln for coire; vid. Anthropophyteia, vol. VII, p. 13. For instance, anus is called the "Cyclopean eye": Ibid., p. 44. Also, Fr. "Cyclope"; the "one-eyed affair"-das "ein-äugige Geschäf" - means homosexuality: Anthropophyteia, vol. II, p. 428. The vagina is also called the "ear between the legs"das "Ohr zwischen den Beinen": Anthropophyteia, vol. I, p. 339. 
and she wonders at the meaningless "allow." She had the ugly habit of boring her nose, which in most cases is a symbolic displacement from below. Here the introitus of the nose replaces the one below.

Let us analyze another dream which shows even more plainly than the former one, this displacement from below.

Mr. Theta dreams:

(33) I am engaged in conversation roith J. L. and $I$ become areare of the fact that I have a flat fleshly growth at the back of my head and I reach my right hand back to it.

I don't like its presence there and I reflect how to get rid of it.

Now it has the appearance of a smooth soft sreelling.

I press on it with the left hand and at first there appears a little bloody drop and on pressing further a bloody fluid trickles forth and the swelling goes down. I look around for something to soak up the fluid; I am using for the purpose perhaps a handkerchief in my right hand but what I want is a sufficent quantity of cotton.

Mr. J. L. offers to go down and fetch some for me. There must be some in Dr. Stekel's office.

Meanrehile I am busy with the swelling, cleaning it and throwing the soaking cotton into the chamber pot, which stands under the bed, filled with urine. But I have the feeling it reill shock J. L.'s sense of 
propriety when he returns and finds me thus making use of his chamber pot.

I also believe now that he is present in the room.

Our conversation room was originally an office and has changed into a living room while I was busy cleansing my wound.

The Puay of the Rook

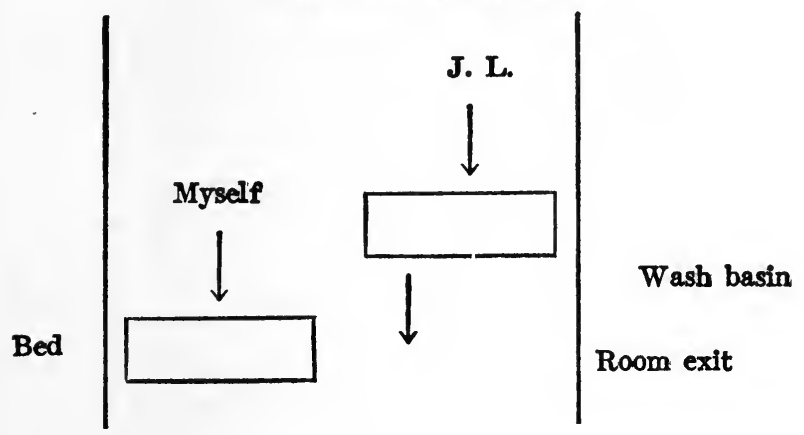

This dream represents chiefly a symbolic account of the treatment. The dreamer is conversing with $J . L$., who afterwards changes into Dr. Stekel. His head is not in order. He carries his neurosis like a boil. I must free him of that boil. I must clean away the filth (matter, blood, urine. I must show him another path, I must direct him (the room roas originally a Direktionsgebäude). Incidentally he wishes an intimate preoccupation with his various Sekreten ("secreta," and "secrets"). Here we encounter the second symbolic parallelism. All 
secreta and excreta are equal to one another. $M u-$ cous secretion (nasal, cerumen, etc.) blood, ether, urine, bowel excreta, spermatic fluid, milk, sweat and tears are equal.

This symbolic parallelism will be considered more fully later. We shall then take up the particular parallels.

We return to our dream. The soaking up of the running matter rouses the suggestion that this represents suckling at the nurse's breast (pus for milk).

This dreamer has not yet forgotten his nurse. Nearly all his dreams are concerned with the nurse (cp. in the chapter on Nurse Dreams the dream No. 249). Here the swelling is also the breast. Thus, we have a transposition from below upwards and backwards. In this connection re become acquainted with a third symbolic parallelism: Breast, thumb, toe, arm, hand, foot, loin, and penis must be considered equal to one another. ${ }^{2}$

The patient's mouth is his erogenous zone. He is a "taster" and "mincer," he likes eatables and has a refined palate.

Now we proceed further with the analysis.

I become aware of a flat fleshly growth at the back of my head and I reach my right hand back to it.

Bearing in mind the displacement from below we find this to represent a touch on the posterior parts.

2 Testicles and ears should also be added. With the exception of the penis, all are paired organs. 
This sort of contact plays an important rôle in the man's rude love life. Taking into consideration also the displacement behind (from the front), the swelling is his penis, which he has thus touched only too often. In spite of his 39 years of age he is still masturbating.

$I$ 'don't like its presence there and I reflect hore best to get rid of it. This part of the dream reveals the dreamer's "psychic hermaphroditism." $\mathrm{He}$ would prefer to have no penis. He would like to be a woman. Castrations phantasies have played an important rôle in his mental life. . . .

The further course of the dream portrays a masturbatory act which was always a "milking" to him. $\mathrm{He}$ is the wet nurse who is being "milked." This betrays his fellatio phantasy. ${ }^{3}$ Puellae publicae have repeatedly carried out fellatio on him. But the wish refers specificially to fellatio by a man (his friend J. L.).

A further condensation is proven by the recall of a serious gonorrheal infection. For a long time squeezing the urethra brought forth suppuration and for a time, also blood. He used cotton at the time to avoid spotting the linen; the handkerchief, after masturbating (Selbstbefleckung).

J. L.'s offering to go down is the critical point. He must go down (hinuntergehen) and replace the "Watta" (he called his father "Atta") with his

"He plays both rôles: nurse and nursling. 
hand and with his mouth. In this treatment I play the rôle of J. L. and the father. I am his friend and father. The continuation of the dream clearly discloses scatological phantasies. I am preoccupied with his filth. He wants to preoccupy himself with mine.

The "chamber pot" of J. L. is the latter's wife. (Moltke's cynical expression: woman is a w. c.!). That is why he does not want to be seen in the act. Naturally the well-known infantile constellation of associations are roused at this point. The plan of the room is really that of his nursery. The first traumatic incidents take place in that room. (The preoccupation with the chamber pot and the cotton as sanitary napkin.)

Here I discontinue the analysis. I merely wanted to illustrate the problem of displacement.

Let us now analyze another example of a displacement upwards (from below).

(34) I visited relatives. Although it roas Summer I roore a winter coat. I expected to find father there. As I stepped in I sare mother in the place. As she roas the first one sitting nearest the door $I$ greeted her. Then I saw father. I greeted him and kissed his hand. Thought the relatives will imagine I am doing it under compulsion only because I am in their presence. In fact I had to force myself to do it. I am struck with father's red swollen hand which I find repulsive and unpleasant to kiss. 
He enters the parental home (visit to relatives). He hates the father yet must show himself cordial towards him. He should be warm, instead of that he is freezing,- - that is the meaning of his wearing the winter coat in Summer time (scornful love). The mother is at the door. Transposition. He was first at the (mother's) door. That is why he greets her first and the father afterwards. He compels himself to feel affection. The red, swollen hand inspires him with disgust. That feeling of disgust rouses our suspicion. We now find out that he loves his father as much as he hates him. The red swollen hand is the red swollen (erect) penis (displacement from below). "Er soll den Penis küssen" - "he is kissing the penis,"-that is a reference to his suppressed perversion, to carry on fellatio with a man. In fact, this craving is shown in other dreams very plainly and without any masking.

Here, as in the previous dream, we find a remarkable displacement. There the intimation was raised that Dr. Stekel may feel ashamcd. Here another thought is ascribed to the relatives: "They may think I do this under coercion!" Both processes are displacements. In the first instance the feeling of shame because he has to tell me such things ("all such filth") is transferred upon me. In the latter instance the dreamer's own feeling of untruthfulness and insincerity is ascribed to the relatives. "They may think!" The displacement of the affect 
(Affeltverschiebungen) and the transference of the affect (Affektübertragungen) are processes to which we will have frequently' occasion to refer.

A patient dreams:

(35) A palace of the high tower and a park and a lodge of Baron Rosenfeld. In the park I find Rosenfeld, Jr. and speak with him. I fell in love with him.

Analysis: The dream is vain worship and admiration of Baron Rosenfeld. But the Jewish name is enough to awaken our suspicion. The dreamer is sure this is a reference to Baroness Rosenfeld, an old nobility. But further associations prove his assurance false. Palais brings to his mind that the word is expressly pronounced Palaiss, "ein paar Läus" (a pair of lice); Park evokes the name of a Jewish horse dealer, Parcheles ("Parch" is a Jewish slurring expression for "Grindkopf," bald pate; "Zinshaus" suggests to his mind Zins, meaning here, Zinsen - that is, usury. Auf der hohen Warte (the high watch tower): the young Rosenfeld, who owns a villa auf der hohen Warte, too, is a "Parch" (bald pate) in his dream. Ich war ganz verliebt in ihmI was wholly smitten on him,--expresses the deepest scorn and is intended to cover the feeling: "what a fresh, arrogant, unbearable Jewish boy!" The dream is a dream of revenge against his physician and the latter's son. The phantasies of revenge are due to unrequited love. $\mathrm{He}$ is, in fact, in love with 
the son (symbol for the penis,- "the little one!"). He does not want to pay any more without compensation in the form of physical love.

But the dream must also have a meaning in the positive sense. He loves Baron Rosenfeld. This path leads us to another symbolism: the palace, like every dwelling, is the symbol for the body. The park stands for the hairy growth around the genitals. The son is the phallic symbol, already well known to us. The hohe Warte,--high tower, is therefore a reference to the act of erection. Speaking corresponds to the sexual act. And the Zinshaus, 一 the lodge?

Before discussing that more minutely we must refer again to the second symbolic parallelism (which we may call S. P. II).

This parallelism requires restatement in broader terms, as follows: All secretions and excreta, also blood, urine, pus, water are equal to each other in the dream (and in the unconscious). They are also to be considered equivalent to the soul, air, (breathflatus), speech, money and poison.

Bethe (Die Dorische Knabenliebe, Rheinisches Museum, vol. LXII, 1902 ; cp. my extensive abstract in the Zentralblatt f. Psychoanalyse, 1910, vol. I. No. 1-2) brings up many examples proving that according to primitive conceptions man looked upon his various secretions and excreta as containing the soul. The vital power resided for him in the urine, 
excrement, blood, or spermatic fluid. With the latter the soul was introduced into the body.

The language of the people also takes cognizance of such a relationship. Blood, for instance, stands for gold. ${ }^{4}$ A usurer is a blood-sucker; one bleeds for another when becoming poor for his sake. To pump means to borrow money. A man is said to be "pumped out" (ausgepumpter Mensch), that is, spent, when he is impotent. The Gulden (monetary unit, therefore, money) is called Spiess or Speer also the penis. Similarly "gun" means money and phallus. ${ }^{5}$

Every fluid assumes this equation: Milk, oil, petroleum, tears, etc. In the seven volumes of $\mathrm{An}$ thropophyteia there are numerous examples of this S. P. II. Indeed, the penis is directly designated as money (Anthropophyteia, vol. VI., p. 15) or oil is spermatic fluid (ibid., p. 9). Ejaculation means: the penis is vomiting (Anthropophyteia, vol. I., p. 146), or is spitting (ibid., vol. I., p. 74, 142, 143, 144). Elsewhere: the penis weeps (Anthropophyteia, vol. I., p. 364) Einem Mädchen in die Mütze spucken,-spit a girl in the $\mathbf{v}$. . ., (literally bonnet, or cap), for coitus, etc.

If we apply S. P. II here, Zins stands for spermatic fluid. The act of speaking refers to the par-

- In the fairy story about Little Meta blood drops turn into golden ducats. The analogy with the Ducatenscheisser and with the Golden Ass at once suggest themselves.

'The bride receives a gift. 
ticipation of the mouth, as an important erogenous zone, in the love act portrayed by the drearn. He dreams of himself in the rôle of a loving girl. His hatred wakes in him the male energies (Adler). Love makes him a woman. The dream (like all dreams) is bisexual.

I want to show here some other forms of transposition (Umkehrung).

First a dream of Mrs. Alpha.

The Dream of the Suffocating Child

(36) A strange child comes to me. It looks badly and gazes at me with sad eyes. I let it come to the table and give it food. The child devours an unbelievably large amount and seems to be getting satiated. One can see the eating does it good, its face livens up and rounds out and I am pleased over it. Suddenly the child begins to choke and I notice that a bite is sticking in its throat. It turns blue in the face, its eyes pop out and to my consternation I see the child in greatest danger of suffocating. The child turns to me for help in its terrible distress. I know there is no one nearby on whom I can call. If only Dr. Stekel were here! What shall I do? Any minute the child may strangle to death. Determinedly I pry open the child's mouth, in spite of the child's struggles, and I see a great piece of meat sticking in its throat, but so far down that I do not think it possible to reach it with my fingers. There is a cooking spoon on the table; 
- I grab that quickly and ram it with courage down the child's throat, so as to at least push down the obstruction. On reithdrareing the spoon I. find it streaked with blood and I am not a little scared that $I$ hurt the child. But the child regains its natural color, breathes quietly and does not seem in pain. I am glad but, still uneasy over the child's silence, I press it to say something, I want to know whether it is in pain. Then the child calls out twice in succession: Papa!' and I roake up from my dream.

Analysis: A wonderfully well carried out displacement from below. The "strange" child she would feed is her vagina; "sitting at the table," means lying in bed. The "starving child" at last gets "meat." Further, the phantasy is of a gigantic phallus which gets stuck.

How nice it must be to be able to help! is a reference to me. I must solve her sexual misery.

These transparent phantasies are linked with reminiscences about masturbation, in which the "finger" cannot reach the "child" and various objects (cooking spoon) substitute the penis. Finally the dream reveals the transference. The child calls for papa! It wants a father, (father, again in the sense of generating father-hasta virilis). But the true father,

- A common symbolism: the child or "the little one," (male or female) for the genital organ. Further details in the chapter on The Rôle of Relatives in Dreams. 
too, plays a great rôle in the neurosis-as well as the phantasy of fellatio, in which the child represents the mouth.

The patient had quit eating meat for some months past. She has the fear (which naturally corresponds to a wish) that "the meat might stick in her throat."

The onanistic manipulations ("I shove it in lively -I push it in") are often accompanied by such reactions of nausea. The masturbation is linked with various incest phantasies ("The child cried out 'papa!' twice") during two periods : before the tenth year, and after the onset of puberty. Once she injured herself' during the act. Now "fear has repressed in her the love." ( $C p$. the dream of the telephone, No. 13.) Masturbation was always vigorously indulged in and sometimes carried on until orgasm was attained twice ("The child cried out 'papa!' twice").

The "psychic hermaphroditism" is strikingly displayed. She shows that she could behave energetically, "like a man," if a strange woman entreated love. ("How nice it reould be to help others, if I were a physician.") She helped so energetically that she hurt the child. She is a "different kind of man" than her physician. She knows at once what the trouble was with the distressed child. She identifies herself with her "papa" who is a well-known and skillful surgeon. 
The displacement may go so far that there are dreams which should be read in a reverse sense.

Freud once remarked at a meeting of the Vienna Psychoanalytic Society that there are dreams which can be seen only in that sense. ${ }^{7}$ I record herewith such a dream of Miss Etta, especially as it shows also other important features.

(37) 1 I found myself in a gigantic, castle-like, theatrical building and dimly witnessed a representation.

2 Then I climbed some gigantic stairway in that building and I perceived $M r . X$. as he loomed into view a ferw times and wondered that he lived here. I greeted him cordially, he answered curtly and coolly and I thought to myself: "I must put an end to that, he doesn't do anything for me anyway."

3 Then I held in my right hand a crumpled up white paper, a rehite apple in my left hand and I entered a room. The folks there wanted to take the apple from me and I fooled them with the ballshaped paper. I talked haltingly and hysterically when I told the Rosen woman (an actress) about it and thought: "I don't really do it well, it should go smoother,-I don't put my whole self into the task"-And further: "if I can't protect myself

\footnotetext{
"Artemidoros states: "When interpreting the story of $n$ dream one must look it over from beginning to end and again from the end backwards towards the beginning. For it may happen that the beginning clears up the vague and not easily penetrable end, or the reverse may be the case, etc."
} 
against those people, I'll simply strike my brow a blow and roake up."

4 Then I sat on a window sill, next to $\mathrm{Dr}$. Stekel's grown up son and later next to himself. I held the son in tight embrace. "Aha," said Dr. Stekel laughing-“again a bit of homosexuality." Then I let go of the young man.

5 And now I was at N's. A red-haired girl sat next to me and I thought she was $R$ udolph's relative and present lover. Her hair was deranged on one side and I thought he surely had kissed her there.Then she stepped out and I was impatient to be alone with Mrs. N. Her husband sat mutely at the table. I jumped at her, threw my arms around her and hissed between my clenched teeth: "I am always thinking of him kissing her and I cannot bear it. I won't stand for it!-That red-haired scarecrow!" Next I had thrown myself, weeping and exhausted, on a divan. Rudolf was there, also the red-haired girl; Rudolf said to me: "I love you still, though not as formerly." Horrified I jumped up so that he should not see my tears.

6 Next clad in white I walked through a garden feeling bitterly cold. Karl went a little ways along and I tried unostentatiously to snuggle up to him; that warmed me up at once but,-I thought to myself,-it was not nice, and mother was also angry about it; so I ralked on all alone and my teeth clattered with the cold. 
The dream gives an account of her life history and begins with a phantasy regarding the future; we must read it backwards in order to understand it. In her childhood she had a little erotic adventure with a young boy (Karl). She was twelve years of age and suffered terribly of chills; a typical symptom of anxiety neurosis, and particularly of sexual expectancy. A boy lodger, who lived in their house, fourteen years of age, came for a number of weeks to her bed, kissed her (without doing anything more to her) until the mother caught him at it and ordered him out of the house. The episode about the white dress (innocence) and the freezing, refers to that experience. Six years previously she was engaged to a young man, a musician (Rudolph), who after a few weeks confessed to her that he did not know what to do, he was unhappy, he did not love her as formerly. She looked upon the red-haired girl who was more to him in the dream than she herself as the cause of his cooling off. Events similar to those portrayed in the dream had actually occurred. The man who sits silently at the table and cannot help her, is her father who is dead and whom she loved with supreme devotion. She became seriously neurotic on account of going through these experiences and came to me for treatment. How she fancies the cure in this dream is portrayed in the fourth part of it: she holds in strong embrace my grown-up son (one I do not actually have). The 
son is naturally my erect phallus (the patient always has the feeling that something ponderous is about to descend upon her, or that she is about to fill out something big; when she opens her eyes and gazes up to the sky, she regrets that her eyes are too small to take in the whole expanse of the sky). I was able to prove repeatedly her homosexual inclinations,-among them also a certain inclination towards my wife. A form of transference, but little studied thus far, is the transference upon the physician's family, which plays a tremendous rôle. Even my little dog thus became the object of a transference as the result of a displacement from the physician to a member of the household. But the fact that in the dream I goad her about her homosexuality has a particular significance. I do not act like a man, I am a woman, for I give her no opportunity to clasp tightly my son. Consequently, now, after her recovery, she again thinks of marriage; the third part of the dream refers to that. The crumpled up white paper in her right hand, which, as she afterwards recollects, many persons are trying to grab, is the marriage certificate. She does not yield to any one the white apple which she holds in her left hand - later she thought the apple might have been reduntil the paper has been first accepted, i. e., she can be possessed only by way of the altar. She is not satisfied with herself, she has found as yet no suitable substitute for her lost lover: sie legt sich nicht 
ordentlich hinein-she does not put her whole self into it. ${ }^{8}$ Naturally we find here also (Anspielungen) references to masturbation, the latter bear. ing a certain definite relationship to hysteria. The last statement in this portion of the dream reveals tragic thoughts ("if I can't protect myself against these people I'll simply strike my brow a blow and wake up"). She is firmly determined, should she give in to her overpowering cravings, $i . e$., in an extralegal manner, without marriage certificate, promptly to shoot herself the next day. She will simply press the revolver against her forehead and never wake up again or, rather, wake up in heaven; $i$. $e$., then only will her real life begin,-while the revolver phantasy represents also a phantasy of playing with the penis, the phantasy which introduces the fourth part of her dream.

For she has become acquainted with new moral standards; a friendly actress thought one could not become an opera singer with her antiquated views. She is a singer and expects to join the opera stage within a year. Finally she climbs up a certain height from which she is able to disregard some of the moral handicaps. She sees $\mathbf{X}$., the agent, loom-

"She is a man. That is why she can "put herself in." Only in that sense does my accusing her of homosexuality become intelligible. She shows me in this dream wie sie sich "hineinlegen" wïrde, if she were a man. The agent $\mathrm{X}$., that brutal, cynical man, would count for a bashful fellow in contrast with her. (Psychic hermaphroditism). In the end she triumphs. She is above (Adler). 
ing up, a man who anyway does not seem to her energetic enough; although she greets him cordially he acknowledges the greeting curtly and seems not to care for her. Her waking dream thoughts are preoccupied with an unmotivated fear of this man's raw conduct, a behavior on account of which he is distrusted by all actresses. Here in this dream he behaves with unusual decency. That much she has already accomplished with her exercises in climbing the gigantic stairway. And finally she accomplishes her end, she is an actress, and has a dim vision of the unfettered life of an actress.

Part I contains also a remarkable experience dating back to her earliest years. The first activities of childhood take place mostly in a "Hoftheater" (Court Theater). The memory of it is unclear and contains a dim prophecy of the future: she is now an actress at the Court theater. . . . 



\section{VII}

DREAM MASKS - DISPLACEMENT AND FUSION ThE BRAVE SERVANT - CRIMINaL (ASOciaI) INSTINCTS 
Wie im Auge ein Punkt ist, der nicht sieht, so ist in jeder Seele ein dunkler Punkt, der den Keim des innern Verderbens enthält.

[As the eye has its blind spot, so in the depths of every one's soul there is a dark spot which is the center of all inner corruption.]

Feuchtersleben 


\section{VII}

Displacement and fusion are among the means revealed by Freud as part of the process of dream distortion. Some dreams represent a murderer. The analysis discloses that the dreamer harbors thoughts of murder and revenge and that he is endeavoring to repress these unpleasant tendencies. The dream ascribes these evil impulses to some other person. We note further that in the dream a person is the composite of a number of persons. This process is called "fusion" by Freud.

We are introducing now a very instructive illustration. It is a so-called "first" dream; that is, the first dream which a neurotic patient brought up when submitting to analysis. These first dreams are very important. Usually they have some bearing on the relations between the patient and the analyst and as a rule they portray the whole picture of the neurosis.

Mr. Theta's dream is as follows:

(38) I placed on watch within my room, at the left of the door, a policeman who I knew had a revolver. At the left, beyond his observation post, there was a box but that was not enough to cover 
him from exposure to the outside. I had placed him there for protection against any one breaking in. I reflected: it would be unpleasant for me to be the first to get in there. I must send some one ahead. Then I thought: I could take along a servant or some acquaintance if need be, otherwise I should have to go in. It occurred to me that he who would break in first might be shot by the watchman. But the thought flashed through my mind only for a second.

A second dream comes to the subject's mind in a supplementary way:

(39) There was a great fire. I went to the wall. The rall was so low, I jumped on top of it.

This dream portrays various emotions. First the fear of some one breaking in, obviously a dream specifically "feminine." Secondly, the fear of the policeman. Thirdly, the dread of being the first "to get in" and fourthly, concern over what will happen to the servant.

We allow the subject to give his associations to "policeman." In his childhood an officer stood for the personality requiring highest respect. Whenever he misbehaved he was threatened with "policeman." He still has an unpleasant feeling whenever he meets an officer, whether policeman or gendarme, as if he were guilty of some wrong doing. But he also feels himself innocent. He has done nothing wrong. 
This occurrence, this dread of officials and representatives of law, is fairly common among neurotics. It betrays an uneasy conscience to some extent.

That is also the case with our subject. The high "policeman" here is the father whom he fears: er könnte ihm auf seine Streiche kommen,- -he might catch him at his pranks. All "watchful" persons may appear in the dream as "policemen." The husband (in the case of a woman) or the wife (in the case of a man), the strict governess, the tutor, the overseer, etc. At this point the subject is led by his association to the person claiming his highest esteem: the father. Formerly his father had watched him very rigorously. An episode dating back to his third year strangely comes to his mind. He was lying in his father's bed when he suddenly came in touch with the membrum in a high state of erection. He seized it to play with it. But his father woke up and called severely to him: "what are you doing?" These are also the words with which a policeman accosted him once when he started to pluck some roses surreptitiously in a garden.

But,- to return to his further associations. He was strongly under the influence of a certain woman, a friend of his father's whom they called "aunt." This "aunt" watched over him very carefully and saw to it that he always kept his hands in sight. She, too, called out to him: "what are you doing?" one morning when she caught him masturbating. 
"Policeman" also reminds him that he was particularly fond of an uncle, too, named Franz. The latter was a physician and died of syphilis. It occurs to him further that there was another Franz, a man who shot himself, and finally, a third Franz, his own brother.

We thus note that the policeman in the dream is a composite figure consisting of a number of real persons fused together. Thus far we find that the figure consists of: "policeman," as representative of the law, the father, the aunt, the brother and two uncles, of whom one was a physician. It is always safe to surmise that the first dream has some bearing on the subject's relation to the analyst. The policeman also stands for me. But this theme we shall take up later. The policeman seems to bear strongest resemblance to the brother.

We are informed about the recent dream inciters. They are rather significant. While here he lives with his brother. He has been here two days. A sister of his brother's wife, a very pretty girl, a student at the Conservatory, also rooms there. She is preparing herself for the stage. She is rather a flirt. Now he discloses some of his phantasies. He expects to remain in Vienna several weeks. It occurred to him: "you could start something with the sister-in-law's sister!" But another thought made this unpleasant: "suppose your brother catches you at it!" Also: "suppose she is virgo 
intacta?" That would make it most unpleasant for him; hence the dream thought: "I reflected, it would be unpleasant for me to be the first one to get in."

$\mathrm{He}$ is extremely mistrusting. $\mathrm{He}$ is suspicious (in his unconscious) of all his relatives. He notices that his brother is very cordial towards his sister-in-law. Can it be that the latter maintains an affair with her? The sister-in-law is represented by the "box" in the dream. Box, trunk, chest, drawer, cabinet, furniture (old furniture), table, also room, are of ten symbols for woman (German, Frauenzimmer!). The box is at the brother's left. That designation has a certain meaning as we shall see later. It indicates the forbidden character of the relationship. The expression "not enough to cover him from exposure to the outside" refers to that fact; it means that he has been able to see through. There is no cover possible for that affair. The above expression, in the original, "durch den er aber nach aussen gegen Sicht nicht gedeckt war" includes the terms Sicht (sight) and Deckung (cover), each carrying a double meaning. A draft at sight must be honored, i. e., covered at once. ${ }^{1}$ Draft, German, Wechsel, literally, a change; his brother has drawn a Wechsel, i. e., carried out, or made a change from the wife to the sister-in-law. $\mathrm{He}$, too, wants to love her, like his brother.

${ }^{3}$ Cover, Decken, bedecken-begatten, impregnating. 
The brother is frequently a symbol for the penis. Particularly the younger brother. This is true here. Now we understand why he sets up-aufstellt -the policeman twice and what that individual stands for. It is a scornful representation,-a displacement. He turns the aggression into an act of protection. That is a common occurrence in dreams. The dreamer protects himself against intruders and robbers with canes, umbrellas, or revolvers,-all symbols for the membrum. That is the manner in which homosexual acts are represented.

This dream is bisexual and so are all dreams, a fact which has been pointed out by Alfred Adler ${ }^{2}$ in particular. It discloses sexual intentions with reference to the brother and the first intimation of a leaning towards me, or transference. The female in the dream seeks male ideals. The male symbolizes his heterosexual objective as "room" and as "box."

In the dream he must send some one into the room: a servant. ${ }^{3}$ This servant, again, is his-penis. All the various designations for servant, Diener, Knecht, Dienstbote, Dienstmann, Dienstmädchen, or Stubenmädchen are symbols for the genitalia.

In his Tagebuch (Diary) Goethe refers to his membrum virile as follows:

Vid.: Der psychische Hermaphroditismus im Leben und in der Neurose. Fortschritte der Medizin, 1910, No. 16.

Servant for p̉enis, vid.: Anthropophyteia, vol. I, p. 41. 
Und wie wir oft sodann im Raub genossen Nach Buhlenart des Ehstands heilige Rechte, Von reifer Saat umwogt, vom Rohr umschlossen, An manchem Unort, wo ich mich erfrechte, Wir roaren augenblicklich, unverdrossen Und wiederholt bedient vom braven Knechte! Verfluchter Knecht, wie unerwecklich liegst du!

Und deinen Herrn ums schönste Glück betrügst $d u$.

Symbolism can hardly express itself more plainly. Thus our Dienstmann, our servant, is also the penis. It is a clever dream distortion to ascribe the sin to some one else and to represent one's self as exposed to the danger. "Or some acquaintance, if need be," refers to the charming girl. He has no other opportunity for coitus and hopes auch hier nicht ungelegen zu kommen. The fear that the brother may be displeased is expressed in the phrase: "The first intruder-Eindringling-(to be taken literally). might be shot by the watchman!" A light fear of infection also enters into his reflections. One of the first persons that occurred to him associatively was the uncle who died of syphilis.

The heat of passion is indicated by the notion of a great fire: "there was a great fire." $\mathrm{He}$ is burning within. He hopes that the girl is in the same state. The difficulties are not great, there is lesser 
resistance when the woman is also burning with desire. He jumps on top of the low wall ....4

The dream-forming unconscious and conscious thoughts lead us thus far. But the dream permits a deeper insight into this subject's conflicts. Why the fear of the operation of law? Has he committed no crime?

At this point various episodes from his life come to surface under a display of some resistance. On his account a girl once became pregnant and on his advice had a midwife bring on an abortion. He was worried to distraction over the result of the operation and very impatient. He wanted to go and make personal inquiries but was afraid of serious legal complications. Therefore he sent a messenger who did not know him while he stood trembling on a street corner waiting for the answer. That affair left him for a time somewhat nervous and with a certain dread of legal complications.

But the affair is linked to various other episodes. He had once a liaison with a married woman (box on the left side) who, pressed by her husband, made a confession. On that occasion he feared that the jealous husband would shoot him. After that the husband watched his wife at every step. He also communicated with that woman through a messenger. She, too, sent a messenger to him to ex-

The walls also symbolize the protective defenses raised by the phobia against the criminal tendencies. Our dreamer is decidedly criminal in his trends. 
plain away and cancel the effect of a letter which she had written him at the command of her husband at the moment when she made her confession.

Another episode about an abortion enters into the dream thoughts. Indeed, his fear of policemen and gendarmes was not unfounded. The affect was derived from events long since past. It arose from a guilty conscience.

Now we know who the policeman is. The subject feels he must watch out for himself. It is an instance of so-called "split personality"; we shall have opportunity to refer to a number of similar cases. He must look out sharply and guard himself. He must protect himself against his lower instincts, against his secret cravings.

Indeed, he has another reason for watching himself most carefully and for holding himself under control. During the last few years he has had to fight down within himself strong murder impulses against his chief (he is a post office clerk) because he has been twice denied promotion. His chief has a large bald pate. For some time he has been unable to meet a bald pate without reflecting how convenient it would be to knock it with a club. His father, too, has a large bald pate. Here is revealed his deepest conflict. His father and he once went after the same woman and his father, a vigorous widower with a better social position, came out the 
victor. That is a conflict already set in during the infantile life of the neurotic.

He was not at all willing to tell me these matters. I am the police officer to whom he wants to transmit a strange message, $i$. $e$, he proposes not to tell me the most important things. Thus we see that the dream employs the most extraordinary processes of fusion in order to bring about distortion at the behest of the censorship. The policeman is the father, the brother, the physician, his penis, he himself. The Dienstmann his penis, - the true Dienstmann,he himself, and finally the Dienstmädchen, servant girl, bisdem er als der erste eingedrungen and who had to have an abortion in consequence. The policeman is also the aunt and his sister-in-law so that the dream leads to an ambisexual interpretation.

The supplementary dream discloses also a homosexual phantasy. Every "wall" or smooth partition has the meaning of man. (There is no door.)

In short this dream discloses the whole extent of the subject's neurosis.

The analysis acquires a new depth when we recall that "watchman" in the dream means death. That is true also of soldier, gendarme, knight, or officer. They stand for death which watches over us, never leaving us out of sight, as it were.

The box symbolizes the grave and the coffin. He does not want to be the first to die off : "it would be unpleasant for me to be the first . . ." He wants 
to send in some one else first, $i$. e., send some one to his death. The wall is the cemetery wall. The great fire symbolizes life: the self-consuming flame.

He accepts the stumbling block and jumps on the wall: he struggles with thoughts of suicide. $\mathrm{He}$ wants to shoot himself.

That, indeed, is the most deepest and the most significant meaning of the dream. 


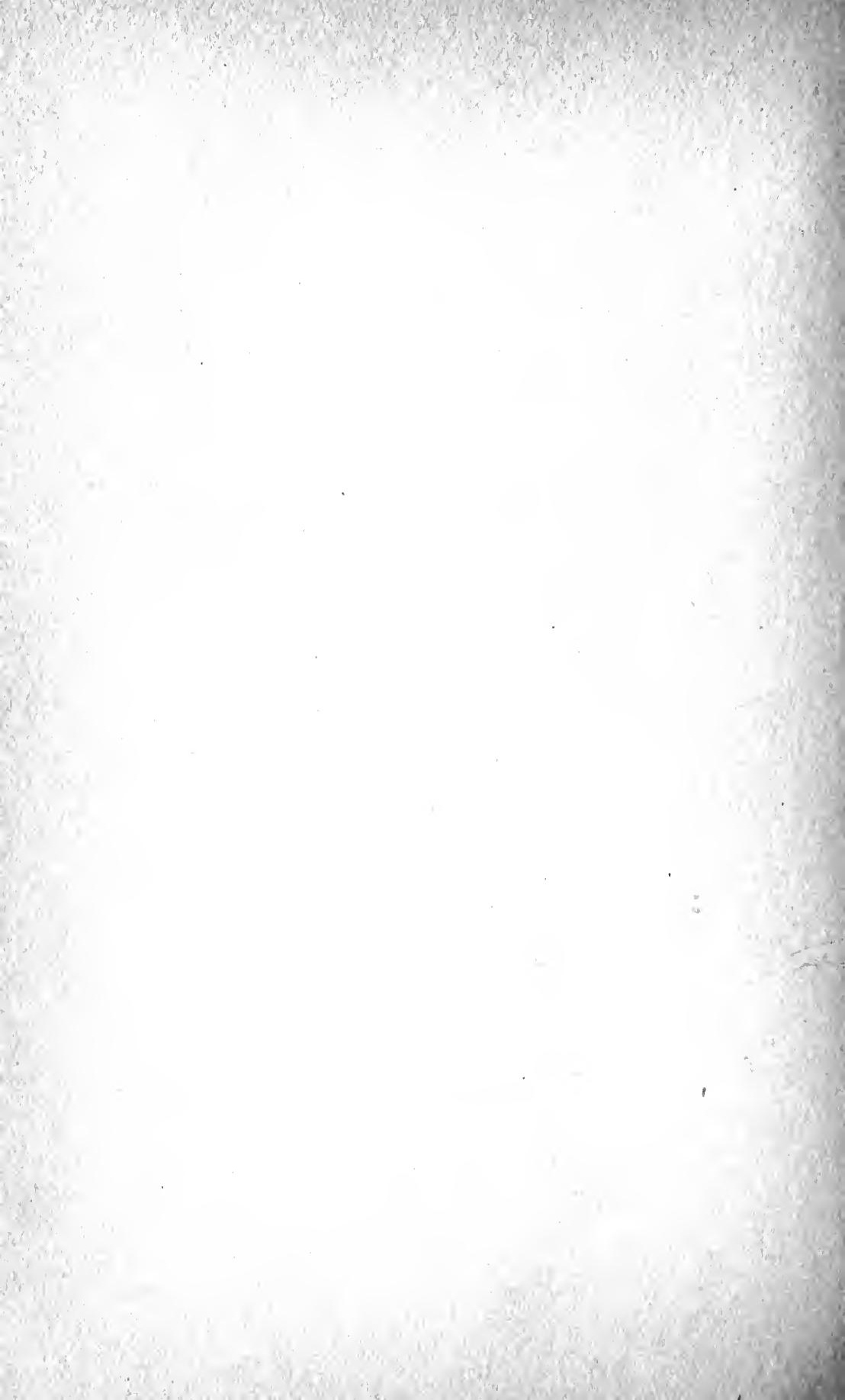




\section{VIII}

THE SPLITTING OF PERSONALITY IN THE DREAM-THE DREAM OF A JUDGE: VILLA AND PRISON-THE MUSEUM DREAM. 
Dass wir uns im Traume selbst sehen, kommt daher, dass wir uns oft im Spiegel sehen, ohne daran zu denken, dass es ein Spiegel ist. Es ist aber im Traume die Vorstellung lebhafter und das Becousstsein und Denken geringer.

[That ree see ourselves in the dream is not unlike seeing ourselves in the mirror without reflecting that it is a mirror. But in the dream the image is more lively while consciousness and thought are subdued.]

Lichtenberg 


\section{VIII}

Splitting of the personality in the dream is a special form of displacement. The dreamer splits up into his good and his evil self. Literally writers have always made use of this device. ${ }^{1}$ Freud, very properly, observes:

"It is an experience to which I know no exception, that every dream represents the dreamer himself. Dreams are absolutely egoistic. When some other person than myself appears in the dream I must assume decidedly that my personality figures through identification with that person. I am rounding out my personality. At other times, when myself appears in the dream, the situation therein shows that some other person is hidden back of and identified with me. The dream warns me to transpose from that person to myself something belonging to that person, to look in the dream interpretation for some masked common peculiarity. I am to ascribe to myself by means of this identification certain features hidden from plain view by the op-

${ }^{2} \mathrm{Cp}$. in this connection my work, Poetry and Neurosis, translated by James S. Van Teslaar. Among such prirs we have Mephisto and Faust, Zanga and Rustan, Franz and Karl Moor, Skule and Hakon, etc. 
eration of the censorship. It is therefore possible for myself to appear variously in the dream, first directly, and again through identification with various other persons. Several identifications of this type permit the fusion of an unusually rich amount of data." 2

We now turn our attention to a dream portraying displacements; it is at the same time a fitting illustration of the splitting of the personality in the dream:

A judge has the following dream:

(40) I had a villa next to a prison and presently it appeared that a room of that villa became a sort of veranda rohich led to the roof of that prison institution. Next I knew that an inmate had escaped from there and there was some talk about it. It seemed to be an uncomfortable situation, the escaped prisoner might break in on us. In fact, as I sat alone in the room looking out through the veranda I sare on the roof a miserable looking, thin emaciated, pale-faced prisoner; his eyes were sunk, he was shaved, and I had at once the impression, dieser Strafling wird sich da hinausschwingen-this pris-

2That is virtually an infantile reaction. At the question: "who did that?" the child always points to "another" person. The dream likewise shifts all evil thoughts unto some one else and attempts in that manner to purge the sense of guilt from consciousness. Similar mental processes are observed among the primitive and simple minded people. "The devil did it!" "It is the work of the evil spirit!" But even persons of higher cultural levels cannot resist always the temptation to project outwardly their inner sense of guilt. 
oner will break away (literally: swing himself out!). Niext I had the impression that the man attackeid me unter Umständen, I seized a knife lying on the table, reent into a little room separated by a glass door from the first, locked myself up there and watched through the glass door. Great God! I thought to myself, he may perhaps break through the glass door and I should have to drive him off with the knife.

This is a very characteristic dream for a judge. Of course the neurotic's feeling of guilt breaks through this dream with great energy. The dreamer has a number of things on his conscience, naturally of a sexual character; his standing fear is that his wife will find out about his erotic adventures and that would disturb their marital happiness. This would be particularly the case if one of his paramours became pregnant as the result of his adventures. Some of his escapades directly endanger his social position. He could not express that more clearly in the dream than by conjuring up a prison next to his villa. We see in this dream the splitting of the personality to which $I$ have already referred (Faust, Mephisto, etc.) and the process is very beautifully illustrated. $H e$ is the man sitting comfortably in his villa, but he is also the prison inmate, the inconsiderate light-minded individual breaking in and disturbing the peace and happiness of his home. He would like to prevent the 
intruder from breaking in. This leads to the image of closed door, a picture typically recurring whenever persons are afraid of temptations; the dream shows that they can always draw the latch so as not to allow the passions to break through. In such instances the passions are represented as wild beasts, horses or criminals.

Moreover this dream carries also another meaning. In his office there is a woman, of rosy appearance, well-nourished, with red cheeks, with light Basedow-eyes and a rich growth of hair (compare the inversion in the dream: miserable looking, emaciated, pale-faced . . . eyes sunk, shaved, Schroingen (Hinausschwingen) leads to schwangern, and to Umständen; ${ }^{3}$ both terms refer to pregnancy. At the office he is separated from the woman only by a glass door. Their relations at the time are merely platonic, a small partition still divides them but he proposes to attack that prisoner with his knife: Hence the expression in the dream: "Great God! he may perhaps break through the glass door . . ." That the defense really means an attack is indicated by the course of the wish fulfillment of the dream. The splitting of the personality in this dream becomes of particular importance because it enables the dreamer to retain his conscious self clear and free, although he is also the prisoner. The lat-

'The expression "unter Umständen" refers to pregnancy. $C p$. the colloquialism: "In andere Umstände kommen." 
ter with his pale, deep-seated eyes is also the symbol of death.

The bisexual character of the dream is noteworthy. The struggle with the prison inmate is a punishable homosexual deed; considered inversely it is an act of aggression (with his phallus) upon the woman in the office who rouses his passion. I may take this opportunity to point out a remarkable fact: judges, prosecuting officers, and attorneys betray very commonly a "criminal complex" in their dreams. Our judge is really a double personality, a fact very clearly expressed in the dream. Such dreams are a common occurrence. $A$ woman dreams :

(41) I see a great boggy field and Miss $M$. must cross it. I warn her saying: "One usually sinks down there!" Nevertheless she runs ahead, becomes covered with dirt but laughs over it and calls back to me: "Try it!" I know I should not sink and although it did not seem to me quite right, 1 went) fearlessly ahead.

She struggles with temptation and personifies that trend of her inner self through Miss M. She warns herself against the large City "bog," but her unconscious makes light of the dangers, it urges her not to mind the dirt and to go ahead. Finally she does so, without injury to herself. She would like to experience and taste a great deal but she is afraid of the consequences. Her case is a very fitting illus- 
tration of the cynical witticism: Morality is the fear that something will happen! (Simplicissimus.)

Following are two beautiful illustrations of the splitting of personality in the dream:

(42) I sarw myself as in a vision which disappeared rapidly. It roas in the open. I saw myself much smaller-but with the traits of a grown-up person-hands and feet nailed on the cross. A couple of men wanted also to drive some nails through my head. I said: "That is too much. It was only a crown of thorns."

"In the dream it seemed to me that I was looking on thoughtfully leaning on my arm." She sees herself nailed to the cross. She is still a child, so young, and she must already suffer so much! The neurotic cross in her case is a severe neuralgia involving the whole trigeminus and extending across the back. ${ }^{4}$ The two men are her two sexual ideals, von denen sie eine Defloration roïscht. The nails through the head are a transposition from below and signify congressus. The crown of thorns is the Jungfernkranz,- - the crown of virginity, - and she would not be pained at its loss. The Jungfernkranz was for her but a crown of thorns. The two souls in her breast, the strictly moral and the passionate, are very fittingly expressed in this dream.

- Or, as she expressed it: bis ins Kreuz (cross). Her severe neuralgia fortifies the phantasy of being nailed to the cross, which is fused with phantasies of defloration as a form of expatiation. 
A great sin weighs upon her shoulders. She loves two men and is passionately yearning for them. ${ }^{5}$

These sinful "yearnings" have burdened her with the cross of her neurosis. Here her sadisticmasochistic trend comes also into play . . .

These trends are expressed even more plainly in the following dream:

(43) I was in a museum (Panoptikum) standing before a glass box containing a very beautiful woman. She said: "You see-such are the low depths to which we drift when we do not control ourselves. Now I must expose my misery and shame to public gaze!" I looked at her and she turned greenish, yellorerish-like a corpse or wax figure. I kept looking and her body was in two (an upper and a lower part) and there was a snake curling within. The snake grew and the split between the two parts (of the body) spread gradually larger. A man was standing near her-he was much more horrible looking-with terrible, great, blue glass eyes, yellow face. He said, that was nothing! When only the passions turn into crimes! I really do not belong to the Panoptikum, but in the torture chamber. I am a criminal, only I have carried out my misdeeds

- Of course fancies of being overpowered, so common among "virtuous" girls, also play a rôle. She wants to achieve gratification without guilt and without having to overcome her feeling of shame. More than that: she wants two men at the same time. An obscene picture roused this phantasy of a congressus a trois. Nail, naturally is a phallic symbol. Nageln for coire, vid.: Anthropophyteia, vol. II, p. 89. 
in such a way that no one is aware. I have kept the trophies. He shows me a fish bladder like a glass globe-transparent (like the inflated balloons sold at fairs). The trophies consisted of a finger and also an eye, ${ }^{6}$ among other things. It was like a glass eye automatically moving its lid; up and down, continuously. The wax figures kept changing size, becoming alternately larger and smaller; they rose high and collapsed again. Suddenly the hall turned much more spacious. I made for the door which I saw at a distance. I was like paralyzed,-I could not move. But suddenly I found myself near it only I was unable to take hold of the door knob. Finally I found myself out-of-doors and $I$ saw a long corridor-I ran and ran-and $I$ sare the wax figures staring at me. At last I reached the stairway which seemed endless. I could not go on, I sank down. I thought to myself: You are on Karlsplatz anyway! There was a wax figure-standing below. I reflected: I am that! Then I said: No, that is Salome! She held a bumpkin in her hand and as she threw it after me I awoke.

Analysis: She sees the course of her iife. The museum is the treatment. She lies stretched in a

- Eye as symbol for vagina: first symbolic equation. Finger displaces penis: third symbolic equation. An eye automatically moving up and down refers to the reflex movements during coitus: displacement from below. Moreover, the eye, like most sexual symbols, is bisexual and signifies also the scrotum: Anthropophyteia, vol. I, p. 215. A finger and two eyes $=$ the male genitalia. 
glass box and must allow me to look through her. The snake which divides the body in two so that the split grows gradually larger hardly requires interpretation on my part. The division is on a horizontal plane as it symbolizes the split between soul and body. The spirit is strong, but the flesh is weak.

"The human race or the human being is like the noble Melusina," states Hebbel, "passably tolerable down to the umbilicus-below that, a monstrosity." Similar expressions are found in Nietzsche and in Shakespeare. Our dreamer, too, sees herself divided through sin (snake) into a noble and an unmoral part. This division becomes gradually more pronounced. That points to the tragedy of the neurosis - the repression.

But taken literally, too, this dream picture bears an important meaning for her. She dreams of lost virginity,-secretly sacrificed. The fish bladder must protect against the danger of pregnancy. She dreams of doing it secretly behind her parents' back. The name of the beloved man who should do that is Karl (Karlsplatz). Salome again represents a splitting of herself-but stands also for Karl's wife whose wrath she dreads. This woman told her once that Karl, her husband, is using fish bladders as a protective measure because they do not want to have any more children. Fertile as she is (bumpkin) she would otherwise have a dozen chil- 
dren. She went once with that woman to the opera "Salome."

The man with the fish bladder is vice-her seducer. The "finger" is also playing a rôle in the seduction. The automatic eyes are the eyes of a prostitute luring men. Die Schreeindeln symbolisieren die Schreinerei. The wax figures,--die Wachsfiguren=rachsenden Figuren sind Penisse. She does not go on, she sinks down. She is a fallen woman. A birth phantasy is linked with that. It seems the fish bladder has failed to do its duty. The bumpkin is a symbol of fertility. The dreamer really sees only herself but under five different forms: (1) the woman whose body is divided by the snake; (2) the experienced prostitute; (3) the masturbator (the finger) ; (4) the cruel sadist reveling in bloody phantasies; (5) the male who turns into a criminal.

We have here again a bisexual dream with strong criminalistic trends. The wax figures, like love of statues indicate a repressed necrophilia. ${ }^{7}$

Necrophiliac trends are very common among neurotics and break forth as a dread of dead bodies or graves and is sublimated as love for statues, wax figures and dead objects. The motive for the infantile phantasies of necrophiliac character is found in the defenselessness of the dead: Anthropophyteia, vol. VI, p. 249. A proof of the persistence of these phantasies may be seen in the necrophiliac oaths of people standing on a somewhat higher cultural level. $C f$. the Oaths of Croatians, Anthropophyteia, vol. I. That is also true of the oaths common among the Roumanians. Vid.: Anthrop., vol. II, p. 293. 


\section{IX}

TRANSFORMATIONS AND BISEXUALITY-THE MEANING OF FIVE FINGERS-AN OLD DREAM IN A NEW LIGHT-BISEXUAL SYMBOLS-ALL DREAMS ARE BISEXUAL-HOW THE DREAMER SEEKS THE MALE IN THE WOMAN 
Es gehört unter die Vorzüge des Menschen dass er träumt und es roeiss. Man hat schwerlich noch den rechten Gebrauch davon gemacht. Der Traum ist ein Leben, das mit dem unserigen zusammengesetzt das wird, was wir menschliches Leben nennen.

[It is part of man's advantages that he dreams, and he knows it. We have hardly made proper use of the fact. Dreaming is a life which together with ordinary living forms the whole of what we call human existence.]

Lichtenberg 


\section{IX}

The transformations of the various persons and even of things appearing in the dream has always been known as characteristic of the dream. Someone plays the piano. Suddenly the piano is a piano no longer,-it is a woman. The woman changes into a tiger. In this manner the dream expresses processes of identification. Piano, woman and tiger are to be considered identical. In other words : one can play on this woman as on a piano! But she is very emotional. I should not care to rouse her jealousy. She would show herself at once a tiger-cat. This rather minute association of ideas is expressed through transformations.

Sometimes through such a change the dream expresses doubt or vacillation between two wishes. When, for instance, an anxiety hysteric dreams:

(44) $A$ bird bit me on the finger. Then the bird changed into a cat rohich jumped at me.

these two different creatures express psychic hermaphroditism. The man is expressed through the bird (penis), the woman through the cat (vagina). Or some one dreams of a naked woman. Suddenly she exhibits a gigantic penis. At the end she changes into a bearded man. 
Other dreams express transformation in the form of doubt.

(45) I sare Mr. N. in the dream. I reas not sure. Later it occurred to me, perhaps it was $M r . X$.

We may profitably examine this phenomenon in connection with a few examples. A woman patient dreams as follows after the fourth day of treatment:

(46) Uncle Charles brings Paul home after dark. $I$ was tremendously scared and asked whether we ought to put Paul to bed at once. Charles turned around to me but when I looked at him, it was not Paul, I sawe instead Dr. Stekel's dark face. On account of the fright I had just gone through I felt exhausted and leaned my head on my arm.

Analysis: Part of the situation is true to life. Her uncle did bring his wife "Paula" to the house after a serious injury in an automobile accident. Paula was her best friend. Charles, her strongest love. An unhappy love which was soon at an end. An end, in an external sense. She broke off all relations with him. But inwardly she still loves him with all the affection of a lonely girl who feels herself getting on in years and who yearns for affection. Her next strongest attachment is to her brother Paul. He too is brought to the house seriously injured, $i$. e., he dies soon. Naturally only in a symbolic sense. He dies so far as her heart is concerned. I inherit all the affection. She trans- 
fers to me all the love she had felt for Charles and Paul. I must encourage and uphold her.

The transformation of Charles into my person is the symbolic expression of the emotional transference. Our pictures blend into one. I am identified with Charles and-as is shown by another dreamwith Paul. (All the wishes of death against the brother now flare up again.)

Miss Etha dreams;

(47) We are to move from our old dreelling; terrible disorder in all the rooms. The servant girl suddenly brings in a couple of calling cards and says: "I have shown the gentlemen to the front room."-It is Hugo with a strange man. He brought the stranger along,-I think to myselfso as to make sure of being received. Mama went with me to the front room. It looked dusty and bare, mama passed by Hugo without a word. I began to talk with him. "You are wholly changed in appearance," he said. "My appearance is no longer any concern of yours," I answered. Then I suddenly felt sorry and began to caress his hair. We sat side by side on an upturned sofa. "See, now I am almost roell," I said. He looked incredulously at me. "And I was very seriously ill,-nervousness," I continued, thinking to myself at the same time, "and that is for the most part your fault." Then I told him about Dr. Stekel. "It is all non- 
sense," groveled Hugo. "So," I said, "the other physicians pay no attention to the soul; yet that is the chief factor in every case of illness." I held him in embrace, he changed into a big hound, gradually shrunk in size and suddenly it was Schary $I$ was holding in my arms and caressing.

This dream becomes intelligible when we find out that Hugo was the young man to whom she had. been engaged and that he had broken the engagement. He calls accompanied by a strange man. That is the manner in which the dream portrays the fact that Hugo has become estranged. The overdetermination of the idea of a strange man is also shown by the fact that he is to be received in the front room. Hugo has never acted towards her as a real man. The stranger is here also a phallic symbol. ${ }^{1}$

We note a number of transformations in this dream. Hugo is a stranger to her. ${ }^{2}$ But she, too, is changed. The upturned sofa also testifies to the great contrast between the past and the present. Once they spooned on the sofa. She would lie down, he sit near her. Sometimes he turned wild and began embracing her passionately. She would be all astir thinking: what next? But nothing happened.

'An additional overdetermination,-the significance of "strange man," or "the stranger," as representative of death, -will be explained later in connection with our systematic account of death symbols.

The psychic mechanism of this occurrence is explained more fully in the chapter entitled "The Feeling of Strangeness." 
Hugo is no man. Less now than ever. He needs. no sofa. What for? It is no use lying down either. They both sit on the upturned sofa. (References. to "sitzenbleiben," literally to "remain sitting," a German colloquialism for remaining single and to the "Umsturzen" or upset conditions.)

Her illness is a matter of the past. She had been very ill. Now she is well. . . Next, I enter into the situation. She points out that I am concerned with the soul. That is the chief thing, she says disdainfully. Hugo turns into a big dog (scorn?). Suddenly he becomes my dog, the dear little Schary who is present at all the analyses. The dog represents me. Specifically he stands for my animal personality. $^{3}$ The series of transformations Hugogreat dog-little dog-Schary-Dr. Stekel-expresses the emotional transference from the unfaithful young man to me.

The next two dreams are those of Mr. Omikron, a compulsion neurotic. They also show a transformation which is the clearest proof of identification.

The first part of the dream shows that the patient's masturbation is linked with secret incestuous phantasies. We shall presently find out on whom these phantasies are centered:

(48) I reent down some stairway accompanied by a girl whom I recently met. She says to me I must

'Dogs in the dream represent "shameless" sexuality. Mopseln=coire (Anthropophyteia, vol. III, p. 222.); Also "Pudeln." 
bring Dr. Stekel's servant girl an apron,-this will probably be an easy thing for me to do as my sister carries aprons in stock. An apron like that is probably worth about fifteen kreuzer. I promise to do so, the while thinking to myself that such aprons as she has in mind cost thirty-five kreuzer a piece. I coddle up to her; in that moment I see it is my sister. I roas about to kiss her but hesitate. She says I must be joyous, it is all right. I may kiss her.

The figures are explained by the patient as follows: 15-fünf-zehn (fifteen), fünf Zehen (five toes ) - five fingers and signifies onanism.

Thirty-five, according to him means "mit den Fünfen reiss ich" and also points to masturbation (Sich einen herunterreissen). The sister urges him to kiss her,-it does not matter. That was once a fact. He was six years of age $(15=5+1=6)$, the sister was eight $(35=3+5=8)$ when they were together in bed and were playing with one another. She had then asked him to kiss her.

He loves his sister very dearly to this day. A poem by Paul Heyse comes to his mind:

Ein bruder und ein Schwester

Nichts treueres kent die Welt

Kein Goldkettlein hält fester

Als das zusammenhält. 
The apron ${ }^{4}$ has various associations. . . .

And presently he brings a second dream which portrays more deeply the sense of guilt linked to certain infantile incestuous episodes.

(49) I passed by a shore rindow and wholly unareare of rohat $I$ was doing I opened it up and removed some gold chains. I am scared when I reflect on what I have really done. I ran into a jewelry store where I found my sister selling something to the gold worker (or was she there to purchase something herself?). I feared I would be arrested and at the same time I wished it rould happen so that I might be able to state that I do not know rohy $I$ did it.

He himself is the gold worker who wishes to tell me the story of his trauma. Various intimacies had taken place between himself and his sister. He recalls having been told by his sister that during their childhood he had urinated into her mouth. (Urine, -excreta,-gold: Second symbolic equation.) Recollections of passionate kisses and hugging also come to mind. The parents were imprudent enough to allow the children to sleep together for years. He remembers that he told his sister lewd things. There is also some history of fellatio. A girl told him about this when he was ten years of age. He

"German, Schürze (apron),-like the "Americanese" "skirt," -is a vulgarism for woman. 
was terribly shocked and wondered whether he ought to tell his mother. Finally he did so and felt very much relieved after that. He suffered of a pronounced polyuria at the time. He had to run several times hourly to the bathroom. . . .

The dream records that he has robbed his sister of the precious jewel, innocence. His conscience troubles him on that account as well as because of his incestuous thoughts. (For more detailed analysis $c p$. Dreams Nos. 34, 102, 314, 315, 318.)

The transposition of my servant girl into his sister shows that back of all his female ideals stands the ideal of his youth,-his sister. The dream airs the riddle of the choice of an objective. My servant girl (who wears a white apron) attracts him because she reminds him of his sister.

I close this account of transformations with a dream by Epsilon, an artist. It is a typical bisexual dream.

(50) I walk along through a "joy" street and I approach a girl. When I am near her she changes into a man who is lying on a sofa half undressed. He says: "Es wird dich doch nicht genieren" oder "es geniert Sie doch nicht": "it weon't discommode you," or "it surely makes no difference to you (that I am really a man").

The man seemed elderly, he roore side rohiskers which were gray. He reminded me of a good friend of papa's. 
The prostitute changes into a friend of his father's and then into his father whom he thus surprises in a bawdy house. The changing of the girl into the father shows the mechanism of transformation. He plays the rôle of the father when he goes to women. He seeks the father when he identifies himself with the mother. His vacillation between man and woman is exhibited in the dream through the transformation. The bird which changed into a cat, too, illustrated the same thing.

We have analyzed, thus far, fifty dreams; rather lightly and superficially. Practical considerations make it necessary that I should limit myself only to the most significant and most pertinent details. But in every dream where we took the trouble to investigate this point, we came upon the problem of bisexuality.

I now conclude: All dreams are bisexually determined. Where the bisexual character is not visible it belongs to the latent dream thought. On this point my experience coincides with the view of Alfred Adler ${ }^{5}$ who goes farther and who sees in every dream the trend of the female towards the male directive tendency,-the so-called "male protest." We shall speak of that later. Now I propose to give a few examples illustrating how psychic hermaphroditism expresses itself in the dream.

- Der psychische Hermaphroditismus, Fortschritte der Medizin, 1910. 
We take first an old example. Dream nine of Mr. Beta:

(9) I see a great wooden image of Christ before me. I chip off a piece.

We have interpreted that metaphor and found that the dreamer had "taken a chip" out of his divinity. But further analysis shows that he chipped off the middle part, i.e., the genitals. It means that he transforms his god into his goddess. Or else he emasculates his god. We shall see later how powerfully Mr. Beta's neurosis is influenced by active and passive phantasies of castration. The bisexual character of this dream is implied in this emasculation.

The bisexuality of the neurotic, a discovery in connection with which Fliess, Freud, Sadger, Weininger and Srooboda have rendered great services expresses itself in the dreams as plainly as in the "hysterical symptoms" or in the hysterical character. (Adler.)

But how masked bisexuality asserts itself in the dream, how dimly, how cryptically! Let us examine a few examples.

Miss Gamma had a couple of dreams in succession:

(51) I wandered back and forth, undecided whether to put on my blouse or my nightgoron, was restless and in fact could not understand what was the matter with me. 
(52) Charles came and offered me some cigarettes in a box but I did not take any as it was forenoon and I had no desire to smoke.

Blouse or nightgown (Schlafrock) signifies here the restless question: Man or woman? "Do I feel to-day like a man or like a woman?" Her second dream denies her female tendencies. She is a male, therefore she refuses the proffered penis (cigarette). The statement: "I did not understand what was the matter with me" expresses her vacillation between male and female. These two dreams show clearly a male protest, a trend in the direction of maleness.

The next,- $-a$ dream of a thirty-year-old man is clearer:

(53) Dr. X. sits in room, dressed in women's clothes, and seems very stout. He wears a gray blouse. ...

S. T. sees Dr. X., his office colleague, as a woman. Here we find that blouse stands for woman a female symbol. In the previous dream (fifty-one) blouse was a male symbol. I disclose an open secret: all sexual symbols are originally bisexual.

Mr. X. dreams :

(54) For everyday wear I have male clothes, but also a'girl's suit. I go for a walk dressed in the. latter and look so well the part of a girl, no one suspects that I am really a man. . . .

How cleverly the dreamer (53) has perceived the 
feminine character of Dr. $X$. His dream discloses Dr. $X$. as a genuine transvestite. The latter is a term introduced by Magnus Hirschfeld, ${ }^{6}$ who calls transvestites "persons who have a strong inclination to dress themselves in wearing apparel of the sex to which they do not physically belong." Disregarding the qualification of a "strong inclination" and considering merely the tendency to wear peculiar apparel, we may say: All neurotics are transvestites, because all alike are psychic hermaphrodites and bisexuality is an important constituent of their character.

That is the reason why peculiar wearing apparel plays an important rôle in the neurotic's dreams as well as in his actual life. There are, of course, various transitional phases. Among men, long clothes have a special significance. The category includes, therefore: priests, judges, lawyers, bathing room attendants, and generally the handsome young men who resemble the feminine type. The other sex shows: stage women in rolled down stockings, tourists and bicycle riders in "uniform," women with a hairy growth on the upper lip, or with deep voice and male mannerisms; also old women because they resemble the male type. These categories include also men with long hair or with braids (Chinese)

- Magnus Hirschfeld, Die Transvestiten: Eine Untersuchung über den erotischen Verkleidungstrieb (Mediz. Verlag, Alfred Pulvermacher und Co., Berlin, 1910). 
and women with short hair,-the long haired poet and the "emancipated" Mignon with her bobbed curls.

Bisexuality is pivotal in the neurosis and in the dream. Where is there a symbol which may not be used in a male and female sense at the same timeeven if the coöperation of the phantasy be ever so slight!

Let us examine a few examples:

The snake is an exquisite male sexual symbol and represents the phallus. But it may also be used as a female symbol, like all smooth, moist, slippery creatures and represent the vulva. Shellfish and snail are female symbols. Snail,-Schnecke, stands for vulva. (Vid. Anthropophyteia, vol. III, p. 98.) But Schnecke is a term which has also its male gender form,-der Schneck. The latter form is sometimes applied to a woman, as in the expression, "ein lieber Schneck!" But der Schneck also means the penis. (Anthrop., vol. VI, p. 50.) Schneckenhaus (cockle-shell), as a receiver, should be female. Nevertheless it is used for the penis (Ibid., III, p. 189). The plural form of this term-die Schnecker,-is bisexual and means: the pudendal hair.

Mouse and rat are terms also used in a bisexual sense. (Vid. Anthropophyteia, vol. I, pp. 143-144; ibid., vol. III, p. 52, p. 186.)

This is also true of broom (Anthrop., II, p. 26); of lamp and its constituent parts (ibid., p. 141, 
230); of fish (fishing-coire; vid. Anthrop., I, p. 251); of toad and frog (ibid., II, p. 132), etc.

This widespread double use of sexual symbols is a vestige of pagan hermaphroditism; of that early period when divinities were represented (and, of course, thought of,) as giantesque females with a large penis or as males with full grown breasts. Symbolic comparisons express essential identities. "Einem penis melken" means masturbating. The penis is treated as a teat. Such details disclose psychic hermaphroditism.

The bisexual divinity is disclosed also in the dream images of the neurotics. Probably not all dreams are as transparent as the following, obtained from a twenty-year-old neurotic:

(55) I dream that I lie in bed with mother and I embrace her warmly. As I move my hand downwards I discover to my consternation a tremendously brg, erect penis. I awake with an outcry.

This neurotic has a peculiar fixation of his libido. $\mathrm{He}$ is attracted by large, muscular leg calves. This sexual objective rouses his libido irrespective of the sex. He wears women's stockings which must reach at least to the knee and, in spite of a heavy growth of hair, he takes great pains to shave himself very smoothly. Other men wear arm bands, or are interested in toilette articles, use perfumes, etc. These traits may be shown in the dream.

Even more interesting is the tracing of the 
peculiarities of character perceived either as male or female. Dr. Alfred Adler, ${ }^{7}$ of Vienna, has rendered a great service to science by pointing out this significant fact and he has made thereby an important contribution towards our better understanding of dreams. He points out that the psychic hermaphroditism shows itself among male neurotics even physically in the form of a female habitus and that the reverse is also true of female neurotics. All neurotics suffer of a feeling of inferiority ${ }^{8}$ and attempt to overcome their trivial female traits by their "male protest." Psychoanalysis must be able to trace in every case (1) the female traits; (2) the male protest and (3) the formulations which represent the compromise between these two tendencies.

Adler has analyzed, among others of the kind, the following "two dreams of a prostitute": 9

(56) I sare before me a man with a comb incidentally'sticking in his hair. I had a feeling of dread which increased as I realized that the creature had horns and a tail.

"It is obvious that we have in this dream-thought the well-known symbol found in all religions, - the devil. But that does not disclose much about the character of the dream. One does not need to have

- Der psyschische Hermaphroditismus im Leben und in der Neurose. Fortschritte der Medizin, 1910, No. 16.

- A. Adler, Studie viber die Minderwertigkeit der Organen (Urban-Schwarzenberg, Wien, Berlin, 1907).

'Zeitschrift f. Sexualwissenschaft, 1908, p. 103. 
recourse to dreaming to conjure up the mental image of the devil. Freud, whose conception of the nature of the dream I am able to corroborate in most essentials, sets up as the test that the dream analysis has been carried out properly, the tracing out of the wish concealed in the dream. At the same time the anxiety which accompanied the dream reminds us that we must expect to find the wish fulfillment deeply concealed and protected against discovery by a resistance which could not be overcome during the waking state. During the dream the psychic process of dream formation must have been able to overcome that resistance and the accompanying persistent feeling of dread must be viewed as the obverse,-as standing for a wish repressed in the waking life but attaining its maximal intensity in the unconscious. We need to bear in mind one more point in order to appreciate, at least approximately, the character of that wish. The anxiety bears only partially on that point,-briefly it indicates that the repressed wish belongs to the sexual realm. We refer back to the peculiar incident that the person in the dream wears a comb in the hair, - a positive emblem of femininity; the person thus represents a she-devil rather than the devil. The explanation of the she-devil is easy. In all probability the dream image under consideration may be traced to the repressed Lesbian trend, and the wish fulfillment consists in the replacement of man by woman. The 
demoniac attributes refer back to the dreamer's childhood when all sexual excitations were considered as roused by the devil (religion, confession). Interesting is the linking together of religiosity and perversity which here rouses the suspicion that either may stand for the other."

(57) I thought that I started to cross a river in a boat. With me in the boat there was a young boy whose face was covered with numerous pustules. When we landed I ran up the hill and sare a cemetery. I threw myself down before a monument representing the Holy Mary, I embraced and kissed her and in the end I bit off her nose. After that I had a feeling of dread.

"Numerous pustules on the face, any prostitute, and even others, would interpret as meaning syphilis. It often happens that the physician finds it necessary to explain to some acne subject that he is not a victim of syphilitic infection. Or else, the physician is urged to cure the trouble as quickly as possible because the patient's acquaintances suspect the acne to be a sign of syphilis. The cemetery where the journey ends signifies the fear of dying through luetic infection. The loss of the nose is easily explained, when we recall that this dread on the part of syphilitics is not an infrequent complication of tertiary syphilis. We note again, images borrowed from the realm of religion; and a fusion of woman and religion is presented before our eyes in 
the statue of Mary. Here the Lesbian trend appears fused entirely with the religious trait; that is why the dream portrays what wakink activity holds wholly under repression. If we should attempt to formulate a synthesis out of the revealed psychic processes it must be approximately as follows: As a Lesbian I should not be in such great danger of luetic infection,-at the most I might bite off the nose of my beloved through love." 10

Since the publication of the above dream analyses Adler has applied the principle of bisexuality to all dreams.

We now turn our attention to a later dream analysis by Adler. (Vid.: Die psychische Behandlung der Trigeminusneuralgie, Zentrble. f. Psychoanalyse, Vol. I, No. 1.)

A twenty-six-year old man, suffering of trigeminal neuralgia dreams:

(58) I am naked in a room with the beloved. She bites me on the thigh. I give an outcry and roake up with a severe paroxysm of my neuralgia.

"The inciter to this dream was an event which occurred the previous evening, as follows: patient had received from Graz an illustrated postcard on

${ }^{10}$ In my opinion "necrophiliac" trends also break through here. The holy mother of God, too, is bisexual,-representing God and,-next,- the father. The dream seems to indicate castration-and fellatio-phantasies. "The young boy" is again the prostitute herself; and the boat carries her into eternity, where she will have to account for her sins. (One source of her anxiety state: the fear of hell.) For her life of sin she is plunged in hell. 
which there were a number of signatures including his brother's and that of the girl who figured in the dream. During the evening meal he had no appetite and he suffered a slight attack. Concerning the dream he relates: the girl had been one time his sweetheart. But he tired of her and in a short time he lost altogether his interest in her. A short time ago his brother became acquainted with her. $\mathrm{He}$ warned his brother but without any result, as was shown by the joint signatures on the card. That hurt him especially as he otherwise had a strong influence upon his brother and, since the father's death, he had assumed, so to speak, the latter's place to the brother."

"Naked": He disliked undressing himself before the women. He particularly avoided exposing his genitals. That, undoubtedly, was due to his cryptorchism.

"She bit him in the thigh." 11 This rouses merely the following association: the girl had all sorts of perverse ways,- - she had also bitten him. The somewhat suggestive question whether he had ever heard

"The experienced analyst will have no difficulty to understand this passage. We have here a patient whose illness aims to cause him to fear pain. Other data in the course of the analysis revealed a precocious knowledge on his part of the pain involved in child-bearing. And during his childhood that pain was made plausible for him by the idea: the stork has bitten mother in the leg! "She bit him in the thigh," in this connection means practically: she has degraded him to the level of a woman, she has humiliated him through her relation with his brother. Similarly, with other neurotics: "to be bitten" by a dog, or by insects. 
of any one being bitten in the thigh, he answered by referring to the fable about the stork.

"I cried out": He does so during severe paroxysms. Then his mother rushes to his side from the neighboring room to quiet him down, sometimes to give him a morphine injection.

"We believe that the dream is sufficiently transparent and therefore extensive attempts at synthesis are hardly necessary. The dream expresses clearly a feeling of being degraded, but it also brings on an attack; that enables him to attain a symbolic aim: to get close to mother. In other words, from a woman (he is being bitten) he turns into a man. His stigma of unmanliness,- - his cryptorchism,--must also give way in this connection, so he appears "naked." $\mathrm{He}$ is a man, he need not cringe before anybody, - but he is that only through the bypath of neuralgic pains. And he secures for himself this feeling of male superiority-precisely as in the childish morbid situation-through pain." 12

While $I$ believe that the analysis of this dream should have been pursued more deeply, I want to illustrate in connection with some of my own dream material the viewpoint of Adler which is important for the psychoanalysis of dreams, and this will serve to illustrate the foundation as well as the limitations of his method of inquiry. I accept unreservedly the concept of "psychic hermaphroditism," but I find

12 Pains here mean, of course, "female" weapons. 
that the principle of the "male protest" has only partial validity. . . .

When we appreciate the continuous swaying of the neurotic between the male and the female ideal, many of the transformations of the dreams become at once clear to us: particularly the change of man into woman and the reverse transformation. The dreamer who finds his father as a puella publica (dream No. 50) betrays through that dream his own psychic hermaphroditism. He seeks the male in woman ${ }^{13}$ and he seeks the woman through the male. Just as he is man, and woman at the same time, he seeks a similar ideal in others. For every one seeks himself in others. "To love means to find one's self in others," says Hebbel.

How unbelievably subtle the expression of psychic hermaphroditism may be, and how clever the search of the male ideal,-portrayed in the dream,-is shown by the following dream of Mr. Zamara.

The analysis is furnished by the cured subject himself. It is here reported in his own words:

First, the dream:

(59) A friend invited me to spend Christmas evening roith him. I accepted the invitation. I sarw in a hall an exhibition of Christmas gifts for sale, especially little horses, which were being packed up during the evening. The Christmas trees, too, were

1a Finally he triumphs over the father. For he is above (Adier). 
loaded with toy horses; I helped packing up the things. Then, when I thought of looking up my friendi it turned out that I had lost his address. I asked a girl in the hall for the man's address; but I could not understand the girl's talk, although she repeated the address several times. I thought, how very strange, we (Austrians and Germans) speak the same language and still we fail to understand one another. Presently I saw a large group of men and women. I wanted to ask one of these women, for the address, thinking she must know; but, to my joy, I see my friend among those present. I realk up to him with the question: "Have you also madel your purchases this evening?" On receiving his affirmative answer I added: "I would have been unable to look you up because I had forgotten your address." He picked up a box of cigars and offered me one.

The dreamer writes:

"The analysis of this dream is very easy. A friend invites me to spend a 'roeihevolle Nacht' with him. First I come across some Christmas shopping. The Christmas trees and the little horses are to be understood as representing the male and flemale genitalia; the hall, where I see all these wonderful gifts, refers to incest fancies and to birth phantasies; it is to be regarded as a symbol for the maternal body. My homosexual trend, weakly intimated at the beginning of the dream, is very adroitly 
and most fittingly expressed in the conversation with the girl: 'how very strange! We speak the same language and still we fail to understand one another.' Thus, it is a case of misdirected love; I will never 'arrive at an understanding' with the girl; the link that ties us is nothing less than the male, for whom I yearn with all my heart and for whom alone I look-without avail-through woman. The dream does not end at this point; it carries out openly the thought of homosexuality and at the end it portrays the complete wish fulfillment. I am happy that I am not forced to get in touch first with a woman for my man's address; I need not have recourse to this round-about manner for sexual gratification, for I see the man I am after, himself, standing in the hall. A joyful Christmas now for me! And how can we,- - the friend and I,-celebrate the holiday of love more fittingly than by uniting ourselves in love? The homosexual union is actually carried out,- the friend 'offers me a cigar.'"

Thus far the patient's analysis. It displays the whole raw side of psychic hermaphroditism. He meets many women,-an acquaintance among them. ${ }^{14}$ In every woman he looks for the man. He asks her for the male friend's address. He and

16 In other words, the women have a familiar face,-his beloved mother! The expression "darunter" is to be taken not only as meaning "among them," but literally. The image of the sweetheart covers the overdrawn memory-picture of his own youth. 
the woman speak different jargons. We now understand why this subject never married,-indeed he had never had a serious love affair.

$\mathrm{He}$ is a Don Juan wandering from blossom to blossom. He is continually searching,--looking for himself, because he identifies himself with the mother. He plays the rôle of the mother searching for her only child.

Another point towards the elucidation of the case: before the analysis the subject was unaware of his homosexuality although it was the source of his neurotic symptoms. Now he knows his enemy within and this insight enables him to cope with it.

It is the triumph of light over darkness. 


\section{X}

SYMBOIISM OF LEFT AND RIGHT IN DREAMS-THE COUSIN AS SUBSTITUTE FOR INCEST-THE FATHER MUST LEAVE-SYMBOLISM OF THE SPIRALDREAM ABOUT DIPLOMATIC BEHAVIOR 
Das ist die rahre Symbolik, wo das Besondere das Allgemeinere repräsentiert, nicht als Traum und Schatten, sondern als lebendige augenblickliche Offenbarung des Unerforschlichen.

[True symbolism is the representation of the whole by the part, not as dream or shadore, but as the living momentary revelation of the Unknowable.]

Goethe 


\section{$\mathbf{X}$}

We find very often that it is of significance whether the dreamer walks to the left or to the right in his dream. The road to the right always means the right road; the left road, is the path of crime. $^{1}$ Left may mean incest, homosexuality, perversion, while right means marriage, etc. The implied values always reproduce the subject's own scale of moral standards. For instance, intercourse with a prostitute may be symbolized by the left path in the case of a minister of the gospel, while in the case of a free thinker who is repressing incestuous fancies the same relationship may be represented by the right road. This symbolism of position has been known for a long time. In his ballad where the angel is represented as standing at the right and the devil at the left, Burger says: "Lass dich vom guten Engel warnen und von dem Bösen nicht umgarnen." "He who gets out of bed with his left foot first will meet with ill luck," is a popular belief, signifying of course, the membrum virile on that side. The legal wife is at the right; left, means an

'This fact is fully dwelt upon by Artemidoros, loc. cit., p. 50. 
irregular liaison. I have always found that the neurotic vertigo is always to the left and $I$ consider that an important point in differential diagnosis. Dizziness to the right is suspicious of organic disorder. One often hears the neurotic complain that he feels himself drawn to one side. Ask him towards which side and he invariably answers: the left. ${ }^{2}$ In left-handed persons the symbolism of right and left may be reversed, as I have had occasion to find. Whether this may be actually a factor conditioning the psychic determination of left-handedness itself is a problem which remains to be investigated and further analyses of left-handed persons are required to decide the point.

The perception of right as male and of left as female, is even more important (Adler). Fliess ${ }^{3}$ who has endeavored to formulate a biologic basis for bisexuality found that the right side means homosexuality, the left side heterosexuality.

Aigremont has some very interesting remarks about the symbolism of right and left in his extremely edifying and fascinating study entitled: Fuss- und Schuh- Symbolik und -Erotik (Deutsche Verlagsaktiengesellschaft, Leipzig, 1909).

2 Occasionally there are variants: the patient, for instance, turns to the right and claws the air in the attempt to reach some support. Sometimes this symptom is to be interpreted as signifying lack of confidence in the marital partner or in one's relatives. Also, the thought: I have lost all support in life! may be thus dramatized.

'W. Fliess, Der Ablauf des Lebens (F. Deuticke, Wien). 
The dream makes copious use of the symbolism of right and left, as I shall now prove by a few examples. A patient (compulsion neurosis) dreams:

(60) I meet Miss F. K., who comes towards me arm in arm with a man. I greet her with great politeness as I pass by. It gave me a jolt at first and I prepared myself for the greeting at the proper moment, namely, I changed my cane from the left to my right hand. The gentleman and I exchanged a peculiar look.

The man who comes to his mind is an employee in the Sammenkontrolstation. The first Sammenkontrolstation had been erected by his father who also instructed him about the evils of masturbation and looked carefully over his laundry. Miss König (King) is the queen,- -his mother,-who comes towards him, which is precisely what he wishes secretly; he also bears great respect for his mother: "I greet her with great politeness while passing by." Further: "It gave me a jolt at first," i.e., his love goes back to childhood, to the time when his mother bathed him and put him to bed. If he misbehaved, his mother gave him a little push and shoved him to the middle of the bed, between herself and the father, an observation post which seems well adopted to lay the foundation for neurosis. His hatred of the father dates back to these early opportunities for observation: "The gentleman and I exchanged a peculiar look." The gentleman, as the "owner," 
has the right to give a peculiar look. On the other hand, Fritzi King is the only girl that pleases him enough so as to think of acquiring her through marriage. Having become familiar with the foundation of the neurosis through my treatment, he wants his cousin, i.e., he transfers his cane from the left to the right hand. The girl cousin ${ }^{4}$ is typically a compromise between incest and permissible love attraction; the cousin is his sister's best friend and the two bear the same first name. He may thus indulge in the fancy of carrying out the incest, without coming into conflict with the laws or with the moral code. It is the same thing, only he has "transferred the cane from his left to his right hand."

Here is the dream of another, severe compulsion neurotic:

(61) I ride a cycle. My cycle keeps troisting to the left; finally I swing it to the right with all my might and descend. The cycle turns into an animal which seems beside itself with anger and it grabs my finger in the mouth as if to bite it. Then it seems that the animal has only its fore-part, as if the hind quarter or a portion of its hide, were missing; therefore the creature must soon perish."

The following is another dream of this patient:

(62) I ras paralyzed on the right side of my body, I was unable to open my right eye.

- Vid. Abraham, Die Stellung der Femwandtenehe in dor Psychologie der Neurosen. Jahrb. f. psychoanalytische Forschungen. 
This unfortunate man, already in the later fifties, is still fixed on his seventy-year-old mother with all his emotions and yearnings. He cannot marry. One day he falls in love with a girl, and the next day she becomes wholly indifferent to him. He is like one paralyzed on the right side, he has no eye for perceiving the charm of other women. He is unable to use the right eye, he sees only with the left. Now we may also understand his dream about cycling. The cycle, which turns into a beast, is his passion, which persistently swings him to the left. The mother draws him to herself. He holds himself "to the right with all his might," i.e., he has recourse to prostitutes for his sexual gratification. The prostitute is the opposite of the mother type; she is not a woman to him, she is a stranger. But he can meet one only once. If he goes to the woman a second time, a certain relationship asserts itself between them,- - she becomes an acquaintance and reminds him of his mother. Er ist dann unfähig $z u$ koitieren. The creature which takes his finger in the mouth, as if to bite it, is his mother who had the habit of sucking his little fingers. He himself is a bisexual "Lutscher" 5 and would readily carry out fellatio on a man. His most significant infantile phantasies relate to the anal zone. That is why the animal's hind part is indistinct. The phantasies

- Many a mother's boy is a Don Juan with strong homosexual components. $C p$. the remarks on the psychology of Don Juanism in connection with case 28 . 
are in fact wholly repressed. His mother, too, is very old. She once possessed an impressive wellbuilt figure but now her body is shrunk; he is particularly struck by the fact that her hips are lean; she is wrinkled, too; her skin, once so smooth, is now withered; "as if the hind quarter or a portion of its hide is missing; the creature must soon perish." He has a friend, a painter, who always refers to women's skin as their hide. (Cp. Fell, Ger., skin, and fellatio.)

The same patient brings a third dream:

(63) I sit astride on an old piano as on a horse and give it a shake. It starts moving and thus $I$ trot along a shore almost. to the house. I can even play the piano at the same time. I meet a young girl at the right, on the left I come across a man. I am afraid that the thing will suddenly break.

The old piano is again the mother; the shore refers to a birth phantasy; the shaking, or trotting, and the playing need no explanation. The young girl whom he meets, is some one with whom he was once in love,-a very wealthy giri,-and he could have married her, but for his awkwardness. The man he passes by is his father, who is dead and whom he has therefore outlived. ${ }^{\circ}$ The fear that

- Überholen, to overtake, or, to outrun, very common in the sense of Überleben, to outlive, "Jemanden auf dem Lebenswege einholen" is the picture which individual existence suggests to many a fellow traveler on the pathway of life. The end of the "long lane" is death's dark door. 
"the thing will suddenly break," is wholly justified. The prospect with the girl broke up on account of his incestuous fixation; as a child he had a tremendous fear of his father, which is the more justified in the dream, since he plays upon the father's old piano. His mother is fragile, very ill,- she may die any day. Again we see the interplay of birth and death; the mother, who had given him life, is now about to die. His birth was such a severe labor that his mother nearly lost her life. In this dream, too, the right side, on which he meets the girl, represents what is permitted, heterosexual married relations, while the man on the left represents the subject's homosexual leaning.

The dream of another patient is as follows:

(64) My father, Miss $N$. and I reve at a place on the southern railroad (Hinterbrühl). We trav elled afoot and met a man leading a very ungovernable horse. The horse reared and hit me; I urged father (and Miss N.) to hurry out of the woay but in spite of that they did not move from their spot to the right. I fell down, but I had been hit only very lightly and I merely felt a roaring in the right ear.

The dream does not end here. But for the present we must limit ourselves to a brief analysis of this portion of the dream. Fräulein $N$. was a governess who had relations with his father. Southern railroad, like all southern places, denotes deep pas- 
sion. References to sun, fire, Spain, Italy indicate the heat of passion. Here this is also indicated by the name of the place: Hinterbrïhl. The patient's immediate association is brûler (Fr., burning). This is a reference to a place where he has made certain intimate observations and where der Hintere (the posterior part) plays a great rôle: am Abort. He suffers of a troublesome itching of the parts and he is a confirmed anal erotic. The expression "we traveled afoot" refers to his strongest passion,foot fetichism. The man they meet is his teacher who was also his first seducer. Through that man he has experienced a number of serious traumata, partly relating to the posterior parts, and these episodes furnished the occasion for his first homosexual pleasurable feelings. Uncontrollable horses always mean passion,-also all wild animals: lions, tigers, mad dogs, etc. Strict oversight by his father and the governess disturbed his relations with the male teacher, with whom another person is also fused: a slightly older playfellow, who indulged with him in various erotic games; they were caught at it by the father and the governess-teacher and punished. That experience inspired him with thoughts of revenge against his father and these are expressed in the dream with the thought: "I $\mathrm{I}$ urged (him) to hurry out of the way but (he) did not move from the spot. . . " Later this patient developed an attachment to the father which was 
morbidly intense. He was like insane when his father died; his anguish was immeasurable. We see that his extreme love rested on a foundation of equally deep hatred and was compensatory. In the dream the father lives too long, he asks his father to hurry off but his father does not stir from his place. His injury is on the right side of the breast, i.e., the experiences of his youth have disturbed his feeling-attitude towards woman. Those occurrences are linked with his pronounced impotence forming a closely knit complex; for his first act of sexual aggression was prevented by his father; he was severely punished when he was caught (playing erotic "games" with the young man). These complexes are unpleasant.

Popular belief holds that clanging, ringing in the ears has a meaning. "Did not your ears ring?" is a question sometimes addressed to one who was the subject of a conversation. The ringing in the right ear means that he must think of the childhood episode when going with women. $\mathrm{He}$ is (sexually) lame on the right side. But that serious trauma is portrayed in the dream as trivial: "I fell down but I had been hit only very lightly,"-is the way the situation is expressed. This dream shows that references to homosexuality are associated with the left side of the body. (This corroborates the observations of Fliess who holds that many homosexuals are left-handed. According to Fliess the left 
always represents that side. In a case of neurotic anxiety he found an enlargement of the left pupil.)

In the various compulsions the symbolism of right and left plays the same rôle as in the dreams. The patient with the characteristic dream of being injured on the right side by a small horse, also suffered of a compulsion which manifested itself as follows: he solemnly resolved to sleep on the left side until he passed his final examinations. This resolution he has carried out to the letter: now he cannot sleep except lying on the left side. The examination dream, a theme which will be taken up later, always means the sexual test with woman. Freud $^{7}$ does not quote my view correctly when he states that my interpretation is: the patient dreams such a dream because he looks forward to an adventure (sexual) and fears he will not succeed. The fact is he dreads the whole theme of love. The test dream of this patient showed itself, after the final examinations, as a typical recurring dream:

(65) $\mathrm{He}$ is in high school facing the examinations in physics and mathematics and that causes him great anxiety.

But I do not want to dwell here on this dream and its associations; I want merely to point out that his compulsion state has been somewhat anticipated in this test dream. The patient resolved to sleep exclusively on the left side, in other words: he pro-

'The Interpretation of Dreams, translation by $\boldsymbol{A}$. Brill. 
posed to have to do only with a man, specially until the Maturitätsprïfung, ${ }^{8}$ the final test, when he may perhaps discover the path to woman. Thus the symbolism of left and right here reproduces his peculiar compulsive thought. The compulsion was a sort of expiatory deed, a punishment for his sins. Like the flagellants $\bar{s}$ he undertook to punish himself through an act which in turn became a source of gratification for him.

The symbolism of even and uneven (or, straight and crooked) has the same significance as left and right. Crooked paths in the dream mean precisely what they figuratively suggest, evil ways, and they often stand for the subject's perversions and for incest. The path of $\sin$ is frequently represented as a serpentine winding. ${ }^{9}$ Some subjects have these dreams very often,-the dreams become stereotypic. ${ }^{10}$ Such stereotypic dreams I consider the subject's typical dreams, i.e., the dreams which recur often in the same or in a similar form; usually they contain the pattern-motive of the neurosis. Sometimes these dreams penetrate into the consciousness,

- The final examination, upon the completion of the high school course,-Maturitätsprïfung,-which if successfully passed, entitles the holder of the respective certificate to join the University and grants him other privileges (especially with reference to military service). The dream here is a Maturitätstraum. The literal meaning of Matura is obvious. [Transl.]

- Serpentine paths are also representative of snake as the name implies.

${ }^{10} C p$. Chapter XLII of this work. 
- they appear as day dreams and yield a sense of gratification.

A dream of this type, which ended in pollution, is the following:

(66) I dreamed I was climbing a mountain on which there was standing a ruin. When I reached the top it seemed to me I was but a rice kernel, or a millet seed and the rohole mountain seemed made up of the same stuff. I let myself slide down and the rapid motion gave me an exquisite pleasure so that I had a pollution. I was able to rouse this feeling also in the day-time by fixing my gaze on a given point; I would think I am a seed rolling down in serpentine fashion.

The patient represented the rolling down as follows :

The meaning is simple enough. On an elevation, Schamberg, Mons Veneris, there is the ruin,-urine, -bladder. A secondary determination is as follows: the ruin - the decrepit old father, who has the right to be there on top, - is ready to tumble down or fall to pieces, according to the patient's wish, i.e., die. What rolls down is the seed, and it rolls with lightning rapidity. It is therefore, the representation of a sexual act and naturally ends in a pollution. During the day time, through the autohypnosis induced by staring fixedly at a given point, he is able to bring up the same phantasy and induce the same result. 
Another neurotic, who lost his mother at birth, turned his mind very precociously to reflections on eternity, which he conceived as a spiral. ${ }^{11}$ This leads us to a theme which we must consider later,-the representation of life and death in the dream. The analysis showed that the subject was always preoccupied with his birth, which also marked the death of another being. Eternity, death, coitus and birth thus became for him fused images. A compulsive thought of which he suffered was: reherever I come I bring misfortune! He became a murderer in the very act of his coming into the world and he fights off violent fancies which at bottom are nothing but the representation of sexual act. In his dreams snakes play a great rôle,-he sees snakes everywhere,-so that an acquaintance has facetiously nicknamed him the "snake man." The symbolism of left and right is also utilized in his dreams as well as in his compulsions. If he takes a step to the left, he must compensate by taking three steps to the right.

The theme of death and life in its relation to the symbolism of right and left is illustrated in a short dream of Mr. Theta:

11 I recall an abstinent subject who thought he discovered the solution of the world riddle and of all existence in the spiral form. In this case, too, the spiral was the symbol of the "Evig Weibliche," the Eternal Feminine. Spiral, screw, winding stairway, etc., express sinfulness and birth. Turning of the spiral brings the $s^{-m e}$ side into view. (Neurotic phantasy of the eternal return-des Gleichen!-of sameness!) 
: (67) A number of lanterns (Japanese?) hang in a row-one at the left catches fire and burns up.

The lanterns are a number of women. This dreamer is already known to us through his interesting dream about policemen (No. 38; cf. also No. 37). The "burning lanterns" are his sisters-inlaw and sisters, his aunt and the servant girl. The left (in the analysis the sister-in-law) "burns up." That represents fittingly love and death. The flame goes off,- the person is dead. (The aunt is dying.) The flame consumes itself: the sister-inlaw loves him. Lantern (in which a candle is stuck), symbol for woman,-like lamp and candles.

I bring to an end this series by reproducing the dream of a cultured, aristocratic person of high standing, whose dreams are so complex that they tax to the utmost the interpreter's ingenuity. His dreams portray the strangest combinations and the most peculiar transformations. Thus he once had the following dream:

(68) He was in a city where everything was topsyturvy: the law of gravity was reversed, the people roalked backwards, etc.

Having alluded to the difficulties we may be excused for not dwelling at length upon the analysis. Another dream:

(69) Little German residential town. While strolling through the wide park stretching across the hill I meet two romen,- -one is young, the other 
appears elderly. I am a professional diplomat, a member of the cabinet (perhaps Bülow). I regret. very deeply that on account of a previous engagement I am unable to escort the ladies. But we converse standing; I entertain them for about forty or forty-five minutes. Then I pass on to the right, taking the broad pathway towards the temple of the Muses.

Naples. Climbing up some stone steps.

... Geld (money) ... schlagen (striking) ... Riga.

"Sie hat mir ja nie gesagt dass sie mich lieb hat." - "But she never told me that she cared for me."

When he told me the dream, he related first that the ladies had asked him to go to the left instead of going to the right; later he corrected himself: he was asked to go straight ahead. Subsequently he recalled also precisely how the road looked. It led at first straight through a forest and upon the heights it branches into a number of winding paths. Serpentine (winding) has a definite meaning whenever it occurs. It means a "snaky" path; in this case it would be the path to the left,-incest; it would be seduction by a daughter of Eve, through the snake, as in paradise. But the biblical story recalls also the temple and the right path leading thereto,- distinctly a reference to marriage. In fact the subject is interested in a Jewish woman and, being a Christian, he finds it unpleasant. The 
woman's mother in particular and all her Jewish relations he finds intolerable. $\mathrm{He}$ is about to go to Nauheim, - the roads about the place remind him of serpentine windings - to become formally engaged. $\mathrm{He}$ has pronounced resistances against this step. Bülow refers to that. The day before he read that Bülow had announced his resignation from office. He too, would like to resign, but only if he could carry out this step in a very diplomatic manner. This wish is the theme of his dream, for as he recalls, he conducted himself with the utmost courtesy when he expressed his inability to join the ladies.

The little provincial town is Gotha. That place suggests new associations. Bülow has married an Italian Countess. For some time he, too, has maintained intimate relations with an Italian Countess; they were practically engaged. The Italian Countess would be more acceptable to his family than the woman who owes allegiance to the temple. The little provincial town represents the place where he expects to be called as professor. He expects the brevet of a regular professorship; to become a regular professor-he is now ausserordentlicher,-depends on his receiving a call.

In the dream he is a professional diplomat. The call depends on the Secretary of the State Department of Education (or minister) who has full discretionary power over his nomination. Bülow also 
means the musician who was active in Meiningen and who left that town. "Meinige" (mine) is what he calls his bride and he wishes to leave her. But Bülow, the musician, found it easier: for Richard Wagner simply took Cosima away from him. Cosima : reference to cosinus, angle of 40 to 45 degrees; here too the question is one of Gradminuten, degrees). Cosima Wagner, the daughter of Liszt,again a reference to diplomacy, zum Listigen (to cunning,-trickery)-stands here in contrast to Mathilde Wessendonk. Wagner, too, has renounced a love; he abandoned Mathilde Wessendonk when she grew old and chose another. The subject is also being robbed of a love: one of his sisters, - the favorite among his sisters!

Only now we find out who the two ladies were in the dream. They are a fusion of the young woman to whom he is about to become engaged and the future mother-in-law with his sister and mother. Naturally he cannot join the latter through their path in life. He can only entertain them for a time; he did it standing. Forty to forty-five degrees brings up by association the thermometric degrees; no man can stand a degree of forty-five of heat (Celsius); it proves fatal. Forty degrees is the highest he has had. His sweetheart wrote him she is feverish; he is thus allowing her to be consumed with fever. He has allowed himself too, to be con- 
sumed with fever during his youth, with the strongest passion possible: his senseless incestuous fever almost ruined him.

In the dream he does not allow himself to be enticed to the left path road. Instead he strikes out upon the more difficult but also more pleasant road to the right which leads upwards and towards the temple of love. There all the muses are waiting. He intends to build a home which shall be a home for art. He aims to attain high, lofty, genuine love and to extricate himself out of his present precarious sexual situation. At any rate the temple road is also the pathway to his highest ardor. The lowermost depths he reaches across the stony steps at Naples. Shall the marriage come to naught after all? Or should he marry the Italian countess?

"But she never told me that she cared for me." The words . . money ... striking . . . Riga . . . seem irrelevant. But forty degrees brings forth by association, Regiomontanus, the thinker of Königsberg, and that leads to Kant. He does not know whether the Ding an sich,-the thing-in-itself-is worth the sacrifice it involves; he must subject the matter to the Kritik der reinen Vernunft, the Critique of pure reason, if he is to be through with her. Riga-Rigorosum-Rigoros, these associations lead "diplomatically" to erection, erect, and refer also to potentia, a theme already intimated in the expression "standing up." 
The moment he comes into contact with a large vagina (broad path) his potence is at once at an end. He looks perennially for something diminutive: "a little residential town." That leads associatively to the least, the narrowest object he looks for, and it proves to be-the anus. The term Geld, money is a reference to that. At this juncture a mass of early reminiscences disclose anal eroticism.

The temple bears a definite relation to his anal eroticism; it reminds him of a story: a Jew was once ill with diarrhea. Nothing helped so he had tillim (psalms) read for him at the temple and that helped at once. The next day his wife was standing at the window looking out and saw another Jewess hastening along the street. "Where are you running?" she asked. "I am hastening to the temple," to have tillim said for my poor husband; he has been constipated now for the past ten days." "You poor woman," shouted the first one, "nonsense! Don't do it. I know better: tillim constipates."

In his case, too, there was something that had to be loosened up or freed,-specifically his fixation upon the anus.

Now we understand why everything in his earlier dream was represented topsy-turvy. He lives in a large city, he is anything but diplomatic, he runs after every woman he meets, escorts her, and he is not always satisfied to entertain her standing; he does not "burn" intensely enough and he is drifting 
downgrade. The right path in the dream is really the left, and the latter leads into the temple through a small opening; and now for the first time we find out the history of an abortion. At Naples he had the chance to secure a boy, and had he not been strict with himself that episode might easily have led him downwards, "over the stony steps of Naples." Now it occurs to him, dass er beim letzten Koitus unreillkürlich mit dem Finger nach dem Anus gegriffen hat. Es fällt ihm ein, dass er nie die Vagina treffen kann, weil er sie immer tiefer vermutet. Obviously he is seeking something else, namely the anus. Es fällt ihm ferner ein, dass er beim Koitieren riederholt die Empfindung hatte, er befindet sich in einem zu reiten Raume, and whenever that happens he is unable to attain ejaculatio. According to my professional experience, this form of coitus sine ejaculatione occurs only when the subject's sexual desire is centered upon some other objective than his actual possession. In der Vagina dachte er an den Anus.

In this dream, the straight path, the left one, respectively, to which the women want to turn him, is mediated by the incestuous feelings. Every woman is in part his mother or one of his sisters. He had to make a turn of forty-five degrees, as was indicated already in a previous dream, where the turn was fully ninety degrees, i.e., a right angle face about. This time the turn about is but par- 
tial, i.e., what he seeks as his ideal is a compromise between man and woman. Such a bisexual being (Mannweib), capable of replacing at once brother and sister in his life, is the bride waiting for him at Nauheim; therefore, in spite of all resistances, he must marry her and carry her to the temple of the muses. 



\section{XI}

THE DREAMS OF A DOUBTER-THE DREAM ABOUT SWEETS-THE DREAM ABOUT STOLEN BOOKSTHE SECOND VERSION 
Es gibt keine furchtbaren Wahrheiten, die Wahrheit wirkt immer belebend, wohltuend.

[There are no gruesome truths, truth is altways helpful and refreshing.]

Srooboda 


\section{XI}

Before relating the dreams to be analyzed in the present chapter I must tell something about the subject's preliminary history. $\mathrm{He}$ is a severe neurotic, Mr. Sigma, very punctilious in his professional calling, forty years of age, in love with a pretty young girl who is poor. A typical doubter, he feels himself bound by his engagement to the girl. Taking advantage of her absence he wrote her a parting letter. But we learn that this letter, breaking up the engagement, had been dictated by his sister, Rose. (Regarding his relations to the sister, vid. Dreams 82 and 83.)

His great worry is that his bride is poor. Like all those who have been brought up under modest circumstances he is anxious to live well,-to enjoy all the comforts and joys of life. Soon after writing to his bride the parting letter he found himself no longer able to give to his professional duties the requisite attention and energy. For instance, he found himself compelled to read a document over ten times before grasping its import. While listening to people he found his mind wandering away from what they were saying or he asked them irrel237 
evant questions. He learned the Bohemian language as an aid to his profession and he had attained a high degree of proficiency in understanding and speaking the language. Suddenly he found that this knowledge had fled from him and he was helpless in the presence of Bohemians. He suffered of sleeplessness and gastric disorder; his disposition was morose, he feared insanity and sought a psychiatrist who diagnosed his condition as neurasthenia.

In the midst of these worries he began to regret his treatment of the bride. He reproached his sister so bitterly that the latter finally wrote the girl suggesting a renewal of her engagement to the brother. Though this was actually done, he still continued to feel depressed and his condition grew worse. In this state he came to me.

I want to report now the subject's first dreams because these give us a deep insight into the character of this neurosis and of the complex mental processes, which our psychiatrists diagnose as neurasthenia. Incidentally, I may mention that since I have become accustomed to look for the psychic conflicts which are responsible for the neuroses I have not seen any neurasthenia. All our previous ideas about overwork and hereditary taint are false; and the notion that excessive venery or masturbation may be responsible for neurasthenia, or for the condition heretofore called neurasthenia, 
in the absence of a psychic conflict, seems to me also to be untenable. I have discussed this theme at greater length elsewhere. ${ }^{1}$

The patient's first dream is as follows:

(70) I am standing with Mary in front of a little table and I drop on it sweets out of a box. The candies look like great pearls and little stars, white and rose-red in color. I arrange the little stars in a row and say to Mary: now choose!

What does the dream represent? He offers candies to his bride bidding her to make a choice. He has in fact suggested to her an early marriage and he expected that they will soon taste the joys of married life. The little table is a bed. The pearls and candy drops (cf. Freud, Bruchstück ciner Hysterienanalyse. Beiträge zur Neurosenlehre, vol. II) are spermatic fluid. But in the dream the whole picture is tinctured with scorn. For the first association which occurs to the dreamer is the well known Hof richter case,-an army officer who sent sugared pills to his colleagues to put them out of the way. The pills while supposed to be aphrodisiacs contained poison. This association reveals that the dream thought conceals the idea that the bride ${ }^{1}$ The condition which physicians designate as neurasthenia is a composite state. The conception includes anxiety neurosis, anxiety hysteria, lighter forms of melancholia, compulsion neurosis, Dementia praecox and Cyclothemia. In addition to a disturbance of their sexual life, these persons always display a psychic conflict and that constitutes the deepest root of the neurosis. Cf. my monograph, The Causes of Nervousness, authorized English Version by James S. Van Teslaar. 
should poison herself through the sweets. Poisoning, in the language of dreams, means becoming pregnant; he entertains unconsciously the idea of extramarital relationship and the thought has also consciously flashed through his mind; the fear of pregnancy and of its serious consequences breaks out in the manifest dream content.

The intent of the dream becomes even clearer when we obtain the subject's associations to "pearls" and "little stars."

Pearls suggest to him tears; this is an old symbolism mentioned also in Kleinpaul's little dream lexicon appended to his interesting work Sprache ohne Worte (Language without Words).

Little stars first suggests comet, the star "with the long tail." Next there comes to surface a remarkable symbolism: sun as father, moon as mother and the stars as the children; again, therefore, the thought of pregnancy. Lastly the most important features of the starlets occur to him: their sharp edges, the points and pricks. The dream represents him as if he were saying to his bride: Look what awaits you in marriage: many tears, much worry, abundant needle pricks and hurts and all that to pay merely for a bit of pleasure (sweets).

The rose-red color is important. Rose is the name of his sister. He hesitates between white (the pure bride, Mary,) and Rose, his sister; and his doubt, whether to marry or not, goes back to the 
inability to decide between Rose and Mary. (This conflict will be explained more fully in the analysis of subsequent dreams.)

Finally row (arranging the little stars in a row) reminds him that the bonbons are arranged thus in rows, like soldiers, and that Mary was previously engaged to an army officer. In the dream he again offers her the choice between himself and the army officer. Reihe (row) also brings up by association Reue, regret; he thinks, she may yet regret the marriage. His trouble is his inability. to choose between sister and bride. In the dream he leaves to his bride the task of choosing, thus extricating himself from the dilemma.

Let us now attempt to penetrate more deeply into the psychic mechanism. I reproduce here three additional dreams of this subject:

(71) I. I have borrowed one or more books from the library of deputy V. v. Z. But I also had a vague idea that perhaps it was my mother who had secured and brought these books for me. I want to keep the books for myself. I approach stealthily the box where the records are kept of all outstanding books, and watching for an opportunity when I am unobserved I remove therefrom and tear up the record of the books given to me.

$I$ sneak along the corridor of $V$. v. Z.'s residence which is situated in a great and wonderful apartment building. I feel I have done something worong, 
something unspeakably evil, the feeling of guilt oppresses me, and I rould like to remove the traces of my misdeed. But some young boys are standing around along the opposite side of the corridor. I think they are talking about me and watching me.

I reant to break into the room (library). An un explainable dread holds me back.

(72) II. There are two books. One is at my home; the other I took to Mary, or rather I hid in her home without her knowledge.

I ask Mary for the book. She answers: "Yes, I thought it belonged to you, I brought it down to you several times; but you have carried it back to us every time. Moreover I know nothing about the whole thing, it does not concern me at all."

(73) III. I am summoned to Court. 'A soldier brings me the summons. I tear open the envelope and I gather from the summons that I am to appear before the Court to account for my deed.

I am trying to think of means of defense. I shall declare before the Court: "I have not destroyed the library record,-mother did that. But my mother has not done it with evil intent; she does not understand these matters; she is not guilty."

A new person appears in these dreams,-his mother. His guilty conscience, as if he had committed some crime, pervades strongly the whole dream fabric. Whenever we find such a feeling of guilt, or the dramatization in the dream of court 
complaints and accusations of theft, the analysis discloses that the subject is reproaching himself for something which strikes him as wrong or downright criminal. I have already mentioned elsewhere the significance of books. Here the same interpretation as indicated in the previous dream is applicable; the books refer to the man's avarice. He is worried because his bride has no Sparkassenbïcher, no Savings Bank books ; moreover he reproaches himself because he is forced to accept the aid of her savings on account of his failing health. She has one savings bank account and that she has placed at his disposal.

But that does not seem to explain the dream. His mother is poor, she has no connection with the bride's savings bank book. Here the second meaning of book clearly comes into play: A book which any one may read is a symbol for prostitute. Book as symbol for prostitute is explained also on another basis. A woman who turns prostitute receives an official "record book" from the police department (under the European rules for the regulation of prostitution). The Viennese expression, "she has a book" (or "a booklet") when applied to a woman means that she is under the control of the Morals Department of the police.

Finally the term book brings up the word number $^{2}$ a very common term in the sexual jargon. In

'In a large library every book has its record number. 
the dream he seems to reproach his mother for something. He would like to wipe out the memory of some occurrence in the mother's past life (den Empfangschein zerreissen). I drew his attention to this fact. A number of traumatic incidents from his childhood come to his mind. He once surprised his mother in a rather intimate tête-a-tête with a lodger, whose name bears a certain resemblance to the previously mentioned word, Reihe. His name was something like Reihental. Ritter V. v. Z. is associated with the fact that the man has the reputation of leading a very loose life,-also his wife. When they built a new villa, this man said to his friends: "I have here two floors. My wife receives on the first and I on the second. Or, "my wife has her bordello on the first floor, and I keep my harem on the second."

Associations lead from this man to another, Ritter von $X$., with whom his mother was on rather intimate terms. They were neighbors. Once during a terrible quarrel his sister accused the mother of having repeatedly sneaked over to the "Ritter" at night. Here he identifies himself with his mother and would like to wipe out the memory of this misdeed; for he thinks that the whole town knew about it and made fun of it: "Some young boys are standing around along the opposite side of the corridor. I think they are talking about me and are watching me." 
But the reproaches pertain to another, more painful thought. They are generated by the incestuous leaning towards the mother. She is the room, the library with many numbers, she is the box in which the Empfangsscheinen - the entries - are kept (Empfängniss is synonymous with gravidity). He is dominated by an impulse to break into that room and we may now appreciate the meaning of the last observation in the dream: "An unexplainable dread holds me back." The expression has a double meaning. His compulsive hesitation keeps him back from his mother as well as from his bride; for love of his mother, and its parallel outgrowth, love of his sister, which also plays a great rôle, is his greatest stumbling-block, preventing him from taking the step of consummating a marriage.

The second dream portrays a second component of his hesitation, namely doubts concerning his bride. On account of the painful reminiscences of his childhood he fears a second edition of the same episodes through the person of his bride. She, too, may prove unfaithful and commit various misdeeds behind his back. All the mistrust, the scorn and doubt generated towards his mother he transfers upon his bride. No matter how often he says to himself that his bride is not responsible for his mother's conduct, in contrast with his powerful affects, his intellect proves weak. Any one reading the dream over carefully must discern at once what 
it was that he had hidden with his bride; and her defense as well as the honesty of her declaration also become clear: "Moreover I know nothing about the whole thing, it does not concern me at all !"

In the third dream he is cited to Court and he must defend himself. It would lead us too far to attempt a complete analysis of this dream. The associations disclosed intimate relations with another army officer. The most significant feature is the dramatization of the thought that he must defend himself for the commission of incest (his strongest wish) with the mother. The Landwehrgericht is his mother; the Vorladung, citation to court, ${ }^{3}$ corresponds to an invitation,-Einladung. It seems he is trying to excuse his mother. We are on the tracks of a terrible family tragedy, some horrible infantile drama, such as does not appear improbable in the case of an advanced psychopathic personality of the type he describes his mother to be: "But my mother has not done it roith evil intent; she does not understand these matters; she is not guilty!"

Moreover the "citation into Court" incident in the dream corresponds to an actual threat on the mother's part. He brings to light terrible family scenes surpassing nearly everything that the master

Gerichte, Court, in a double sense; it stands also for Gerïcht, rumor. There were ugly rumors current about his mother. 
hand of a Zola has described. He and his sister in the endeavor to put a stop to their mother's scandalous hysterical conduct have had to resort to physical force. Horrible fights broke out and his mother threatened to complain to the police. ... Thus appear at close range the persons who sit in judgment over others. 



\section{XII}

THE SYMBOLISM OF IIFE AND DEATH IN THE DREAMTHE LONG SHARP SWORD IN THE DREAM-MASTURBATION REPRESENTED BY POCKET-THE MATRICIDE IDEA-BLOOD FOR SPERMATIC FLUID 
Virre, enfin, c'est mourir.

[To live, at bottom, means dying off.]

Maupassant 


\section{XII}

In his memoirs of the Russian-Japanese war a Russian military surgeon relates an interesting episode. It was just before a great decisive battle. His regiment was to be among the first to enter the slaughter at early dawn. The sleepless soldiers pressed around his tent with the request to be given some remedy against painful erections. He had to prescribe drastic cathartics to draw the hyperemia towards the bowels.

Similar observations have been made during the last Messina earthquake. While the houses toppled over and the flames broke forth, love indulged in its most abandoned orgies. No chaste virgin, no respectable wife thought of resisting the desires of the frantic men. The proximity of death had roused in all the instincts of life.

Recently the newspaper related a touching episode. A girl, fatally wounded, spoke up to a passing workingman: "Kiss me! That I may know love before I die!" These were her last words. ${ }^{1}$

Where death looms forth the instinct of life also

'Arthur Schnitzler has dramatized this motive in his Ruf des Lebens (The Call of Life). 
asserts itself. In the fairy story about Old Uncle Death and the Healer, who asks for a new flame to replace the declining flame of his life what does Death answer? "I cannot do it! Some flame must go out so that another may be lit."

These observations have led Swoboda to formulate a law of "the Conservation of Life." 2 "It consists of the equivalence between life and death," states Sroboda, "and in virtue of it the shedding of sexual cells-for every sexual act need not necessarily lead to increase of life-involves but a temporary decrease of life." He quotes very properly the dictum of Celsius: Seminis emissio est partis animae jactura.

Thus we begin to understand why the dream often represents coitus under the picture of dying; also the remarkable fact that in the dream murder may be a psychic equivalent of the sexual act. It means possession raised to the $n t h$ degree,-exclusive and last possession.

Let us turn to these principles as disclosed in the actual analysis of dreams.

A very fine-minded, genial woman, painter, dreams:

(74) In a primitive forest there stands a tall, spreading tree. From a branch of the tree spreading far out there hangs a long, sharp sword. Be-

'Hermann Swoboda, Die Periode im menschlichen Organismus (F. Deuticke, Wien u. Leipzig, 1904). 
fore me there stands a man whom I am unable to distinguish clearly. The sword hangs between us and we cannot therefore see and recognize one another. Stronger and warmer growes our mutual longing; with a powerful grip the man seizes the sword determined to drag it down;-I shout exultingly and throw both arms in the air.-He has seized. the sword too hastily, it slips from his hand and pierces me through the heart. I sink down with the sword sticking in my breast. The figure of the man dissolves like a shadow and I am alone lying on the ground, mortally wounded.

Does this dream really portray only death through an accident? Through a man's lack of adroitness? Not at all. This is not a death dream -it is a dream of life. "The tall, spreading tree in the primitive forest" is the penis. The erection is represented as a long sharp sword. "Stronger and warmer grows our longing"-und nun führt er den erigierten Penis in die Vagina. Heart and breast serve as displacement from below. . . .

The "shadowy dissipation of the figure" relates to a dead person. Her greatest love! It is also a raw by-play on ejaculation. ...

Remarkable picture! At the moment when she begins to live, when she begins to know life, she dies.

Just as the dream knows no negative in general, it recognizes no denial of life. In the dream dying means usually the same as living and often the 
greatest life urge is expressed as a death wish. Similar psychologic considerations hold true also of suicide; ${ }^{3}$ even the choice of the manner of self-destruction is influenced by certain erotic factors. This thought has been repeatedly expressed by the poets; philosophers, too, have dwelt on the intimate relations between Eros and Thanatos. ${ }^{4}$ In the dream, as in actual life, murder is often a crime passionelle representing nothing more than a sexual act with a strongly sadistic coloring. A typical dream of young girls: they are standing naked on the street, a big man attacks them or sticks a knife into their abdomen. I have already analyzed such a dream. In such cases the murderous attack portrays a forceful defloration,-what is being killed off irretrievably is the honor; it is the death knell of virginity which, again, means the inauguration of woman's life. Homosexuals dream of attacking a man whom they knock down with a cane. Dreams of this character require no further elucidation on my part.

I turn now to the representation of death in dreams :

(75) My brother is to leave Vienna (?). He has

'Cf. my statements concerning suicide in: Ueber den Selbstmord, Diskussionen, vol. I, 1910 (J. F. Bergmann, Wiesbaden).

The well-known thought of Euripides is an excellent illus-

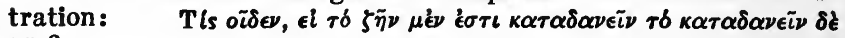
$\zeta \tilde{\eta} \nu ?$

"Who knows whether life is not a dying and death living?" 
already packed up his things in a couple of trunks and several hand grips. Then-he roas not to leave till late at night-he roent to the Club. Meanrohile, I stepped into the rooms while he roas aroay and found furniture and things stored on the ground floor, the first and the second floors. I was accompanied by an old watchman who looked like a museum attendant and who wore a. Bordeaux-red uniform; also he carried a bunch of keys. He explained many things to me in a side room extending backwards, which was very dark, there were a number of red covered mattresses; the covers had white mother-of-pearl buttons. He unbuttoned one of the covers, the mattress underneath was also red but there were no buttons on it. Now the museum attendant began to talk very animatedly: "That is like the conception we Norwegians have of life and death; the cover is life. The buttons are the pleasantnesses and the unpleasantnesses of our existence. When we die the cover slips off and rohat remains is an uninterrupted, uniform state of absolute peace. That is the highest happiness. Sleep continues without the least sensation, unpleasant or pleasant, with the knoweledge that one is dead but that existence continues beyond our earthly life." Then he again buttoned the cover on the mattress. I was very deeply moved by his speech, and I felt a strong longing after that promised state of absolute peace and there came over me that feeling of rest which 
partakes somerohat of the majesty of death. Meanwhile roe climbed up to the next floor, which was the attic. There we found only some old lumber and furniture like the outfit of a carpenter who might be also a collector of antique. Then we walked down the stairs again. I found it roas late and I roanted to find my brother. I saw him on the street on a small square; I was in doubt whether it was G. or my brother; then I recognized it was my brother by his monocle. I returned to the house and I supervised the loading of my brother's belongings upon a hand wagon; the wrong packages were brought down; I said they rere mine, not my brother's. It happened twice; then finally two men brought the baggage down in a hand roagon.

It would not be possible to give here a full analysis of the dream; that will be done in connection with the study of the respective neurotic trouble. But the most important features may be pointed out. The patient is to abandon the treatment. Hence the wish to leave Vienna. He identifies himself with his brother who lives outside Vienna. His brother is a lively fellow who always keeps one or two women on the string. He envies him for his numerous trunks. But he also accuses him of masturbation (handgrips). Club to his mind is a place where members indulge in homosexual pleasures. The various floors refer to his different erogenous zones: he is a foot fetichist (ground floor), anal eroticist 
(first floor) and fellatio (second floor) too, plays an important rôle in his dreams. His childhood memories are represented here by the old furniture. Especially an old nurse, who had mistreated him for years, becomes fused with his servant into the museum attendant.

Next there appear anal phantasies which revolve around childhood reminiscences. The words, "he explains many things to me," refer to that. The side room, "extending backwards and very dark," is noteworthy. Mattresses refer to a number of things. First the name of the servant, next to the name of a certain French woman; there is also a vivid association with the old mattress on which Heine died as the result of syphilis, - a disease which one acquires through sowing wild oats carelessly. The subject suffers of syphilidophobia; "Ratzen" (Matratzen) suggests a similar train of thought: rats spread the infection of plague. The buttons have anal significance, referring to hemorrhoidal knots but they also suggest the glans penis, the red (button) head which is especially hyperesthetic in his case; also the all-important nipples.

The museum attendant's conversation need be explained here but briefly.

"The cover is life": das, was auf den Penis drauf kommt, die Vagina, ist das Leben. Reference, also, to the proputium. He is afraid to draw it back. The cover or covering (Überzug, Überzieher) has 
also its over-determination in a mechanical device for protection against infection.

"The buttons are the pleasantnesses and unpleasantness of our existence": this refers to the pleasurable feelings and the pain traceable to his penis and to his hemorrhoids, respectively.

Living: means also erection; when the membrum virile subsides it is like dead: when we die the cover slips off and there is left an uninterrupted, uniform state of absolute peace, i. e., if our libido subsides, so brauchen wir die Vagina nicht und der Penis bleibt ruhig.

"That is man's highest happiness": in that way he consoles himself for his impotentia. He has wanted to establish a new religion, founded on asceticism and is of the same opinion as Tolstoy in these maiters, or rather he was, for to-day he is nearly well and he has practically abandoned that ascetic ideal. . .

One knows "that one is dead but also that existence continues beyond earthly life": the quiescent membrum does not trouble the potent man because he is certain of a resurrection.

At this point there came to the subject's mind homosexual phantasies relating to his brother as well as to myself; in fact the museum attendant owed most of his features to me; for during the treatment I am his instructor; he obtains from me new psychologic information. I am represented as conclud- 
ing my treatment with a practical demonstration,intimated in the unbuttoning and rebuttoning. . . And his emotions are not surprising: his enthusiasm, his boundless yearning for the promised state of blissful peace, finally his conviction that death must be something majestic. That kind of death merely means living the life of a free man, without infantile inhibitions; it is what he wants to attain and did attain through the treatment.

Further phantasies refer to his brother and his membrum virile. We perceive that inhibitions are the cause of his impotentia; the baggage plays here a great rôle; wrong baggage means false moral views such as have tortured him for years. Another meaning of baggage is genitalia; this points to masturbation, as intimated in the loading of the baggage upon a "hand" wagon.

\section{A woman dreamed:}

(76) I was on the street and felt dizzy; very scared I shouted: "Das ist der Rückfall, das ist bestimmt ein Rückfall! I am falling backwards, I am surely falling backwards! Now I shall die!" 5

- Rückfall, of course, means relapse. In the dream the woman shouts: "I am having a relapse!" The literal translation is given in the text,- "falling backwards"-because the dream, as there shown by the analysis, revolves chiefly around the latter meaning of the term. But the idea of "relapse," with the implied greater ease of falling backwards (in contrast to the woman who has not yet "fallen") and with the additional implication of the wished experience being already something fulfilled also lurks in the background of the dream and supports its main theme. [Translator.] 
This quiet little mother, fifty-five years of age, lived very sedately until her only daughter, thirtyfour years of age, suddenly fell in love with a man who reciprocated her affection and married. This roused powerful erotic fancies in her which led to severe depressions. She envied her daughter the husband and her sexual joys. She began to suffer of dizziness; during the spells she tended to fall towards the left side, - at least she grasped for support on the right. The attempt to support herself usually failed; she had a feeling that the support was not strong enough: that support was her husband,- $-a$ wholly impotent man and the dizziness represented her dread-and-wish to fall. Falling backward is really a stretching on one's back and this explains in a simple way the neurotic fear of many women have of slipping backwards. That she will surely die on account of slipping backwards means really that she is going to live once more. The dream, interpreted, means: I go down the street in search of an opportunity to fall into sin, I fall and taste to my heart's content!

Mrs. Delta, who is under my treatment, dreams:

(yy) It is evening, dark. The girls want to close the shop. We hear a great noise, the cry, "Mother-

As in the above instance wherever necessary I have not hesitated to translate terms in their literal sense and $I$ have occasionally given preference to a somewhat special rendering whenever the trend of the associations in the original required it. ( $\operatorname{Van} T$.) 
murderer!' and many persons run out on the street. We are very much afraid; a procession moves slowly down the street, carrying strong lights. In front there are priests, all in white, then there follows a hearse, also covered with white, on which the murderer is carried; there follow a throng of people. I am very badly scared and the fear wakes me.

Mrs. Delta is subject to incest phantasies. The dream revolves around her much beloved son who has recently married. She witnesses his funeral, she sees him stretched on the white bier, i. e. she pictures to herself his marriage,- the bride dressed in white. A marriage which, in her judgment involves socially the ruination of her son,-at any rate it marks the death of their love. What she expected from him was Muttermord (naturally murder in the sense of a sexual, life-affirming act) ; hence her powerful hatred of the daughter-in-law. Many persons signify a secret, priests in the dream often mean, by a reversal of implications, sensuality clothed in white. Belief in and the fear of ghosts betrays a similar symbolism. Usually the dear departed, dressed in white, are the ones who reappear as ghosts and cause consternation.

The girls want to close shop; in addition to the homosexual phantasies which this evokes the remark also expresses the subject's regret that her daughters are unable to gratify their sexual needs. ( $C f$. Dream No. 25.) 
Transposed the dream is easily interpreted: It is full daylight. My boy shows tenderness towards me and I am pleased, etc. Mrs. Delta's psychic hermaphroditism is expressed also in this dream.

Beginners are easily lead astray by the affects displayed in the dream. We have already seen that love may represent hatred, irony wonder, etc. We can go further and state: Here, too, symbolic equation is operative as a valid principle. This, the fourth symbolic equation, may be formulated as follows: All affects in the dream are equal to each other and may substitute one another.

Let us analyze a dream illustrating both features: representation of life and death and the fourth symbolic equation.

Miss Delta dreams:

(78) I come to the birthday anniversary of my friend Christine. I have not brought along the birthday present. I had no time to purchase it. She is in bed, looks very pale,-like a roax figureand that makes me roonder.

But few words are necessary. Christine is the wife of the man she longs for. The dream means: I come to the burial of my friend Christine. I have forgotten the floral wreath. She died so suddenly I had no time for it. She was stretched on her deathbed, pale as wax and I rejoiced.

Here birthday stands for death. The feeling of surprise or wonder stands for joyful satisfaction. 
A woman, thirty-four years of age, obsessed with the fear of apoplexy, relates the following dream:

(79) I carried my dead brother, dressed as he was laid in his coffin, with the aid of another person and ree reve about to place the coffin in the grave with the body still warm. I said to the other: "See, Franz is still alive, we cannot put him down." There were many other burials and many people around. I arooke shuddering.

She lost her brother to whom she was attached with all her heart. Her only consolation was an uncle,-the other person in the dream. She has fused brother with uncle, a typical incest compromise; she is so deeply in love with her uncle that she could not refuse him a thing. The coffin in which every person first lies, is the maternal body. The same symbolism holds true of grave (das Grab) and in this connection "graben" carries plainly a significant meaning, like "bohren" (boring) and "geboren" (born). Thus the grave stands for heaven; hence the close connection between the grave and heaven in popular belief. The idea is expressed by Rückert:

Du meine Welt in der ich lebe, Mein Himmel du, darein ich schroebe, $O$, du mein Grab, in das hinab Ich ewig meinen Kummer gab and even more clearly by Schiller: 
Noch köstlicheren Samen bergen

Wir trauernd in der Erde Schoss,

Und hoffen, dass er aus den Särgen

Erblühen soll zu schönerm Los.

In the above dream the patient sees her brother, the membrum virile of her cousin, as it was in the maternal body; (dressed as he was in his coffin): i. e. naked and she wants to put him in the grave while still alive, i. e. potent. The accompanying affect pertains to the abhorrence roused by the thought of burying some one alive. But the affect has been displaced; interpreted it means: I do not want to put my husband-who is still living-prematurely among the dead by changing him for the uncle.

"We cannot put him in": this has the double meaning of putting in as well as of betrayal (or unfaithfulness); "einen tüchtig hineinlegen," a colloquialism not unlike our "putting something over" on some one, means: to deceive some one. "Many people" means "the secret"; also the challenge to do it, after all. "Many burials" means: everybody lives and tastes the fruits of indulgence und legt die anderen hinein, why should you alone impose such scruples on yourself?

These dream thoughts are further corroborated through the fact that her present husband did not get along at all well with her deceased brother and 
he would, in fact, thoroughly deserve the punishment. Her most intense desire is to have a child, i. e., to be a coffin herself. She cannot expect a child from her husband for she knows that he is sterile. She wants to get the child from the uncle, she wants to "carry" him with another person; here "tragen," "carrying" has the meaning of being pregnant (as in English). ${ }^{6}$

An abstinent church official, suffering of depressions, dreams :

(80) I sat on a stool in my father's study. Suddenly I felt pain in my body and vomited a stream of blood. I cried: I shall die!'

For many years he was addicted to masturbation until his father warned him: "If you do not give up the habit, you will die." Once he masturbated so inveterately that he caused a profuse hemorrhage from the urethra. During recent years he was abstinent, but he developed serious neurotic anxiety traits; he has a most uncomfortable feeling of pressure and of pain in his body and the sensation that something sticks inside of him and can neither get farther in nor out.

The thing that sticks and cannot get either farther in or out is his penis. Now he is fighting with a resolution to have sexual intercourse. "I

- The dream portrays the phantasy-far from an infrequent one-that she bore and had given birth to her brother. The effect (shuddering) is the expression of her general feelingattitude (yearning) rather than of horror of death. 
shall die": this expression in the dream means,-my abstinence drags me down, I must begin to live.

This resolution he actually adopted shortly after the dream. With the aid of the second symbolic equation the dream is easily interpreted: $I$ am with a woman. Suddenly I experience enormous gratification. I shout: Es lebe das Leben. (Blood for sperma; dying for living.)

His wish to seek regular sexual intercourse was expressed in a short dream which I reproduce without analyzing the details as it is fairly clear from what we know already:

(81) I strolled along a narrow path bordered right and left with bushes. Some little distance from the road, to the right, there stood a woman, apparently waiting for me. When I saw that, I turned back.

This woman was a prostitute whom he had been meeting for the past six days. Bushes are the devil's device; and, like Luther, he would consider it the devil's work were he to stumble. (To stumble, German, straucheln and Strauch, bush; there is thus an additional connection between bushes and stumbling in the German, based on semantics.) The woman stood at the edge of the bush. The symbolic representation of the vagina-narrow path edged with bushes-is very clear.

But the subject is also homosexual and the chief cause of his neurosis is his leaning towards a sister 
in whose company he has experienced his important trauma. ${ }^{7}$ The dream shows that he still has a considerable amount of resistance to overcome. A few days later, as already mentioned, his action belied the turning back incident at the end of the dream.

It may cause some surprise that I should have occasion to dwell so much on incest. But I cannot do otherwise than record conscientiously everything that comes to my attention. The fact must also be taken into consideration that we are dealing chiefly with subjects burdened with ill health. 



\section{XIII}

SPEECH IN DREAMS-THE SYMBOLISM OF CONVERSATION-COLOR SYMBOLISM OF MR. S. 
Schlaf ist ein Hineinkriechen des Menschen in sich Selbst.

[Sleep means man's withdrareal into himself.]

Hebbel 


\section{XIII}

Mr. Sigma, whom we already know through some analyses (vid. Nos. 70, 71, 72, 73), dreams:

(82) Mary offers me a breast-pin as a gift. I decline it saying: "I thank you. You know, needles bring bad luck as gifts. Moreover you will get a better (a living, warm) needle from me.

A rule established by Freud is as follows: Conversation in dreams is taken from some actual daytime conversation. This is very true here. The dreamer's bride, Mary, brought a number of gifts for his sister; but she retained for herself a very pretty breast-pin. The dreamer thought she should have also given that pin to his sister, Rose. Mary said: "I cannot do that; you know: needles bring bad luck as gifts."

Another recent dream instigator may be mentioned: at an outing in the woods the bride (after an embrace) remarked that she lost the breast-pin. They looked for it but in vain.

The dreamer admires handsome breasts. His greatest pleasure is to suck the breasts (hence the symbolism: breastpin), an act distinctly and typically infantile, traceable back to the nursing period. 
Until his fifth years he was in the care of his nurse. He slept with her in bed, played with her mammæ and fell asleep with the nipple in his mouth. ${ }^{1}$ The oral region is his strongest erogenous zone. The dream portrays the thought (also consciously entertained) of intercourse with the bride or of proposing fellatio to avoid the danger of pregnancy.

Another observation by Freud must be mentioned in this connection. He states (Bemerkungen über einen Fall von Zwangsneurose. Jahrbuch $\mathrm{f}$. Psychoanalytische Forschungen, vol. I, 1909): “ $E x$ perience teaches us that dreams sometimes portray the actual theme of the compulsive inhibition, etc., which during the waking state is traceable only under the cover of a distortion and displacement, like a cyphered telegram. These themes appear in the dream as conversations, in spite of the rule that speeches in dreams are reproduced from day-time conversations."

Sigma, with whose history we are acquainted through the analysis of previous dreams, suffers of a very serious psychic conflict, which may be subsumed in the simple query : bride or sister (Mary or Rose)? ${ }^{2}$ Every detail becomes a theme of doubt

${ }^{1}$ Once when he had a cough the nurse gave him her own urine to drink as a remedy. An example of symbolic equation.

'In all cases of compulsive doubt I have found that the doubter, during childhood, was placed between two persons to whom he was linked equally with ties of love: mother and nurse or nurse girl, mother and aunt, mother and father. Mr. Sigma seeks expression for his conflict in the typical con- 
to his mind: he doubts himself, his bride, his sister; he questions whether he can make her happy, whether he can support her, whether he can be true to her, whether he will be able to gratify her, whether she will be faithful to him, etc.

This dream shows us his compulsive thought. He wishes that Mary would turn over to Rose the needle (obvious symbol).

She did not do it. He takes his sister's side. Mary and Rose are cousins,-a typical incest compromise. The speech applies to Rose and means: "Be consoled. True, you did not get my bride's needle, but I have another one for you,-a prettier, living, warm one!"

The compulsive thought, therefore, of which he is a victim, sounds: love thy sister! Against this imperative he struggles with all his might and the consequences of the struggle is his severe neurosis.

Is the sister without a share of responsibility for his neurotic condition? One reading over carefully the subject's other dreams should be able to form one's own judgment. Before he undertook the journey to Vienna (to be psychoanalyzed) his sister said to him: "You may marry your Mary; but do not be surprised if I should then find a sweetheart for myself and become intimate with him!" This foolish threat on the part of his sister had worried him

stellation. The old theme-mother or nurse-is brought up now under a new form,-bride or sister? 
a great deal. "It would be his greatest misfortune:" Die Schwester soll keine andere Nadel erhalten. He begrudged her having any one. She must remain single. He is jealous when she entertains herself in conversation with other gentlemen. Neither does he want to give up his bride. He does not want her, either, to have any one else. He would like to hold on to both. The only solution he can find is suicide: that would end once for all these tortures, wishes, cravings and doubts.

Another dream of the same subject:

(83) I see before me, haunched at the right of the window sill, a little yellowish-brown monkey caressing a reddish-gray dove in front of him. Gazing at them I have a feeling that the monkey roill sink its clares into the bird at any minute and I say derisively: "You rould like to eat her, wouldn't you?"

The dove is the kind, bland Mary who causes him so much concern (gray dove). He once said to the sister: "You would drown Mary in a spoonful of water rouldn't you!"

Only the previous day his bride wrote him that she is visited daily by the sister who is very cordial with her. But he knows that his sister hates the poor bride and could "devour" her. Er hat seine Braut zum "Fressen" lieb. He wants to marry her. (Right side!) He thinks he himself is as ugly as a monkey. He is but a monkey. He follows first his sister's and now his bride's bidding. He is jeal- 
ous (yellow) and begrudges his sister as well as his bride another man.

The colors have here in this connection special meaning. Reddish refers to sadistic trends. $E r$ freut sich auf die Defloration. His uncertainty whether Mary is virgo intacta will be solved soon after the marriage ceremony: Sie wird bluten müssen.

Equally significant is "yellowish-brown." Brauner is the name of a man who caused an alienation between himself and a sweetheart. He was very jealous at the time. Gelb is the name of another man who once lodged with them. This man was a great "Don Juan" who brought different women to his room. Once the patient took special pleasure to disturb this "Don Juan" just after he had taken to his room an especially attractive woman. As loudly as he could he sang the refrain: "Indeed, love is a wonderful thing!" and other snatches of songs of like character. How did he know that Gelb was entertaining a woman in his room? "Because the walls were so thin. The door, too, was not noise proof. Moreover, my sister drew my attention to it."

We discover, further, that his sister, too, was rather intimate with that lodger and this again made him very jealous. The singing proved a successful revenge on the part of brother and sister. For the caller-supposedly a respectable woman- 
was so scared that she left the man's room at once. Gelb threatened to beat him until he was black and blue and yellow.

Reddish-gray recalls various associations. Grauer was an acquaintance who, without his wife's knowledge, turned twenty thousand Kronen over to his sister for her dower out of the money his wife had given him. When the wife found that out she demanded the return of her money and threatened divorce. Roth was a young man who courted Mary and who wanted to marry her. Finally, the last association, Tauber, was an officer with red cuffs (he had previously mentioned that the dove had a red glimmer around the neck), who saw a great deal of his bride and who had been engaged to her for a short time. He doubts the innocence of his dove.

Thus the colors "yellowish-brown" and "yellowish-red" show various determinations. Tauber was without means. On account of his military career he had to break the engagement with Mary. That love was hopeless.

The thought of giving up his engagement to Mary is also a part of his own speculations. He will first have her and then put her aside. His sister will help him get rid of the bride. (See the Court dream about poisoned candy!) The words addressed to the sister practically mean: "You would like, best of all, to poison her, like 'Hofrichter' did his com- 
rades." 3 Mary wanted to poison herself. She was prevented from carrying out the deed. The dream intimates all these possibilities. The facetious remark addressed to the sister is really a request and means: "Take her off my neck and yours. Strangle her or poison her-but make me free."

Fearful regrets and thoughts of suicide on awakening. (Lex talionis!) His sadism, almost boundless, breaks through in this dream. This sadism is not only psychic,- - he not only tortures his bride, his sisters and all others around him. He has actually broken out with physical violence. He has beaten and choked his mother. Beating his sister, and dragging her by the hair was a common occurrence. And he is afraid he will also beat his soft bride once he makes a start.

There are cannibalistic trends slumbering in the depths of his soul. He is like a predatory beast that would fight with its teeth. He bites during coitus-he could perhaps devour his bride out of

${ }^{3}$ How often compulsions have back of them imperatives relating to the subject's family circle! A man consults me on account of the torturing compulsive idea that he must put his wife out of the way. A brief analysis discloses that his mother and his wife dislike each other. Once they had a serious quarrel. They grabbed each other by the hair. His mother said to him at the time: "I do not understand how you can get along with your wife. Another man would have put her out of the way long ago." This hypothetical imperative on the mother's part started the torturing compulsive idea; the latter disappeared after being thus traced to its source. 
love. He is the yellowish-brown monkey ready to gratify its cannibalistic instincts on the dove: to possess and kill her in the act,-Sie tötend besitzen!

Again we come upon the association of life and death; this time an aggressive variant of it: Besitzgreifen und Töten. ${ }^{4}$

- I have no doubt in my own mind that all jealousy murders have a pleasurable affect. When Othello chokes Desdemona he carries out an instinctive urge,-er vollzieht an ihr den letzten Geschlechtsakt. Thus revenge becomes for him most pleasurable. Our gratifications involve the destruction of others. We maintain our life through the death of others. 


\section{XIV}

REPRESENTATION OF THE EMOTIONS IN THE DREAMTHE DREAM OF "GETTING READY"-A CLERGYMAN'S DREAM-THE ROOT OF FOOT FETICHISMTRIUMPH OVER THE FATHER-DREAM THOUGHTS AND COMPULSIVE IMAGES-INFANTILE ROOTS OF THE FEAR OF CONTACT-WHY THE DREAMER "WONDERS" 
Ein dienst zu Nacht ist unser Leben Genuss ist fauler Wächter Traum: Vor keinem Hirngespinnste beben,So leicht es klingt, kanns einer kaum! Feuchtersleben 


\section{XIV}

There are in fact no dreams without affects. Dreams unaccompanied by affects, or but slightly colored, are not remembered. That the dream process begins the moment we close our eyes seems to me self-evident. Later I shall give a few examples in connection with the discussion of hypnagogic pictures. We always dream when asleep. When the affect becomes so strong as to rouse our consciousness we wake up. In the same way we remember only the dreams strongly toned with affects. Only such dreams enlist our attention. In fact, attention is an affectative state, as Bleuler ${ }^{1}$ has shown very convincingly. The dream is but an interplay of images in the service of our affects.

The affects which break clearly through the dream are of particular significance because they are the repressed affects.

(84) A roman dreams her husband is unfaithful.

1 Affektivität, Suggestibilität, Paranoia. Carl Marhold, Halle a. S., 1906. Bleuler states: "Our actions are probably influenced exclusively by the feelings of pleasure and of dysphoria; logical considerations receive their strength through the effects with which they happen to be linked." In the same way the dream is not an interplay of thoughts, but a struggle of affects. 
She attacks him with a knife. She hurls ugly epithets at him.

In the dream this woman gives free rein to a tremendous feeling of hatred. When she wakes up she is happy that it was "only a dream." But the dream discloses to us the fact that she is mistrusting and that she hates her husband. More than that. She seeks some justification for her hatred. This woman once said to her husband: "If I should ever find that you are unfaithful to me $I$ would promptly revenge myself." The dream pictures a justification for her hatred and furnishes her an excuse for following the trend of her sexual instincts.

Thus, whenever an affect breaks through in the open it always yields a deep insight into mental life.

But affects, too, are deceptive. Affects, too, may be transposed; substitution plays a great rôle: respect for scorn, overvaluation for depreciation, love for hate. I take this opportunity to emphasize that dreams should be plain even without the transposition. The two emotional trends coexist. The neurotic-like every human being-is moved by contraries. All symptoms, all the manifestations of human thought and feeling, are bipolar. Hate and love, respect and scorn, confidence and doubt, go hand in hand. Any affect may appear either ir a 
positive or in negative form,-either with a plus sign or with a minus sign. Hatred is love with a minus sign. ... We must recall here the fourth symbolic equation. The affects may replace one another.

Often the dream displays an affect which does not fit at all into the content of the dream. Freud has discussed this theme very carefully and I must refer to his Traumdeutung (The Interpretation of Dreams, authorized English translation by $A$. Brill). I may add only that in many cases the dream affect is extremely treacherous and exposes the psychic conflict almost in its naked terms. I am able to corroborate the rule laid down by Freud that in every strongly toned dream the affect is always justified. When interpreting a dream $I$ always start with the affect. In this way we find out how the dream material has been masked through transposition, shifting, etc. and how the affect becomes linked to irrelevant elements in the dream. Trivial data next disclose the character of the affect. Since the disturbance of the affectivity is the deepest cause of the neurosis I put greatest weight on the analysis of the dream affects., Of course, there are also dreams apparently devoid of affects (Freud). But as is the case with compulsive acts, they are only apparently devoid of affect. Incidentally, this has led to the erroneous view, still held 
by many psychiatrists, that the absence of affect is characteristic of compulsions. ${ }^{2}$

The following examples will illustrate how the dream affect enables us to obtain a deeper insight into the structure of the respective neurosis.

A woman patient has a number of typical recurring dreams: every time she gets tremendously excited over something which she does not quite attain. The symbolism is obvious: diese Hetze findet besonders beim Koitus statt. Ihre Angst ist, dass der Mann zu frïh fertig wird, before she attains the libido; her perpetual wish: einmal zurecht zu kommen. This conflict expresses itself in a dream as follows:

(85) Preparations to go out for the evening.t $I$ rush back and forth full of excitement. I open and close the wardrobe, various bureau drawers, the roriting desk. I lay out my gloves, jewelry and the various toilet articles. Every little rohile I think of some additional little thing I had forgotten. The round of opening and searching begins all over.Finally $I$ stand before the looking-glass and let. down my hair preparing to dress it; but it is useless. I cannot get through with the hair dressing. Fatigued by the hopeless strain I lower my arms helplessly. My husband is fully dressed, ready and reaiting for us, to go out visiting. I hurry from

'Stekel, Zwangszustände, Ihre Psychischen Wurzela und ihre Heilung. Mediz. Klinik., 1910, No. 5-7. 
room to room out of breath but I do not find it possible to finish my toilette. Finally I reake up exhausted.

The meaning is very simple. She finds that preparations are being made for a private (secret) entertainment (opposite to "Gesellschaft," society, i. e,. social call) by her husband. She gets ready her small things (jewels). The expression: "the round of opening and closing begins all over" is particularly edifying. ${ }^{3}$ She cannot finish her hair dressing, i.e., she is unable to attain libido; her whole life is a search for libido. All her thoughts revert symbolically to this one theme. Frisieren,hair dressing,-is a well-known expression for coitus. Preparing one's toilet also means congressus (sexualis); it also means, by contrast, undressing. Her inability to "get through," in contrast to her husband, is the basic theme expressed in this and in all her other affectatively toned dreams. To go into society, - to be received: empfangen werden -again, leads to Empfängniss; pregnancy. Her most bitter disappointment: she is childless, there are no children in the home, no companionship, no Kleinigkeiten: no little things. Closet, drawer, writing desk, glove, jewel, little things,-these are alike symbols for the female genitalia. Her hus-

"Das öfnen und Suchen beginnt von vorn:" "the opening (of drawers) and searching begins ... von vorn, over again," but also: "in the front." 
band is already waiting, i. e., he is ready, or rather through (fertig) before she is.

Another one of her dreams may also serve as example:

(86) I lie abed, ill and inwardly agitated. I am worried because my household ${ }^{4}$ does not run smoothly. I muster courage, and disregarding the state of my illness, I rorap a towel around my head and with duster in hand I brush and clean out every corner. The effort exhausts me and I sigh over my helplessness for in spite of my labor and care the work does not get done. Everywhere I still see the old disorder. My mother appears and she scolds me for trying always to do so much. I beg her to help me, this eternal not-getting-through hangs over me like a curse.

The mother who reproaches her stands for womb (Mutter: mother and Gebärmutter: womb). In this dream, too, she cannot get through. That is the curse of her life. The husband is through sooner. $\mathrm{He}$ is, in fact, "all through." She sighs over her husband's impotence der bei der Arbeit kaum den Kopf hineinsteckt. What is the use of her keeping herself so clean, would it not be better if she were less averse to moral impurity,-perhaps the frustrated excitations and her phantasies are exhausting her and make her ill? In the next

- Symbol for the phallus. Popular vulgarism: Lass dir deine Wirtschaft ausbürsten. 
dream, which I reproduce as complementary, she reverts back to her premarital state. She is again a young woman in a position to choose another-potent-husband:

(87) I am again a girl at my parental home. A great feast at the home of my girl friend; her engagement is being celebrated. I am present, not at all sad, but taciturn. Most of the persons present misunderstand my behavior,-they whisper among themselves saying that I am jealous of my friend. I merely smile with an air of aloofness, for I am conscious of my moral superiority and inwardly I resolve to marry only when I shall meet the great! love for which I yearn.

A few words will explain this dream. Her present husband was once interested in that girl friend. She turns her husband over to the friend. Because of her experiences she does not envy her friend, nor the latter's future joys. On the other hand she herself is that friend and she sees herself retrospectively at the time of her own engagement as in a vision: "The great love for which I yearn." It is a dream within the dream; by this means she nullifies her hasty marriage,-goes back beyond it,-for she would now marry only through great love. Great love is the love of a great, i. e. big one (German, gross is both, great and big). She wants to be possessed by a big one. The dream is a very pretty wish fulfillment, it gives her back her youth, her freedom, 
it enables her once again to choose her love. She is single,-taciturn,-einsilbig. One word, the little word Yes, hastily spoken has brought her lasting unhappiness. This time she wants to draw a great winner in the marriage lottery. Her husband was a blank.

Dreams in which the subjects "do not get through" are very common. The dreamer arrives at the theater too late or he misses the train just as it rushes by. These dreams form a contrast to the type mentioned above,-dreams in which the dreamer finds himself unable to get through.

One of my patients who suffered of a severe neurosis was tortured by the thought that he looked like a Jew. He was also afraid that his mother might be killed during his absence. In order to be ready with an alibi he gathered all sorts of memoranda, car transfer checks, receipts, etc. Analysis proved that the foundation of his neurosis was his still persisting passionate attachment to his mother. Jeroish was to his mind synonymous with sensuous. To mark him for a Jew meant: to recognize his sensuality. Therefore he is subject to most uncomfortable feelings when he walks through the streets. He thinks that everybody is looking at him, that the faces show mistrust, - and this has caused him repeatedly the most painful conflicts.

(88) This subject dreams regularly that he arrives at the station just as the train is pulling out. 
He hurries excitedly to be on time but he never succeeds.

(89) Or, he runs after an electric car and cannot reach it. He had the habit of jumping on moving street cars, in order to dodge his pursuers,- - he said. In addition to that he roas always obsessed by the desire to catch a car on the run. Another time he dreamed:

(90) that he roas following an automobile in a roagon and could not reach it.

All these thoughts are based on the fact that his mother is twenty-eight years older than he. This is the tremendous gap which he is unable to cover. His wish was: "Oh! if I were the father! Oh! if I had known mother when she was young!" His father took her away from under his nose. She is ill: he knows that she may die any day and that he will never possess her. Every time he arrives at the station with so much baggage that he cannot get through. This baggage is particularly typical. Nearly always-although there are no fixed symbols and under certain circumstances a symbol may mean something else-it signifies the moral burden which one carries on one's shoulders. Like the pilgrims in Tannhäuser who sing: "Gar schwer drückt mich der Sünden Last." ("The burden of sin weighs heavily on me.") On account of his heavy baggage he arrives late. In the dream the moral inhibitions are also represented as baggage. 
The thought that he may be taken for a murderer is justified. This refers to his feeling-attitude towards his mother. His favorite reading is Dostojersky's Raskolnikow (Crime and Punishment). Murder also refers to the symbolic representation of a dagger being stuck into the victim's body ; taking life means granting life. We have already discussed this theme.

Another subject's dream dealing with the same theme is the following. But here the objective is a married sister, ten years older than the subject:

(91) I am at a railway station and worried because I do not know whether it is the right one. After this worry was over, I thought of buying a ticket. In a pocketbook I find a gold coin with a large 10 on it. First I thought I could not use this coin. Then I decide it is all right. At the same time $I$ begin to worry whether I should catch the train for I had lost time. Going towards the train I found that I had entirely too much baggage. Some of the things I did not need at all. Unfortunately, the baggage that $I$ reas willing to leave behind was not? within my reach; it was left standing at one end of the station,-at some distance. I did not know what to do. Finally I signaled to a porter and told him to take and check my baggage at the "hand-grip" division. I shall reclaim it there upon my return. 'As soon as I roas through I rushed to the train but it roas too late,-the train had just started. 
The baggage here is used in a double sense: the genitalia and (2) the various inhibitions. His sister, ten years older, has been taken away from him through marriage. We shall have opportunity to revert to the meaning of the number 10 in connection with our analysis of the symbolism of numbers: this number consists of $1,-$ symbol of the penis and 0,-representing the vagina. The number 10 symbolizes sexual union, which the subject has not carried out till then, for he was a masturbator. ${ }^{5}$ That is the reason why he looks for the coin in a pocketbook. He thinks first of his sister's. Hence his worry whether he is at the right station,-his doubt whether he can or should use the coin. He is too moral to commit incest. Indeed, his moral scruples-he is a theologian-prevent him from carrying our ordinary sexual intercourse. He has never touched a woman, except his sister, once, when he was twelve years of age, but there was no immissio penis. The expression "was left standing at one end of the station" refers to that. His scruples are clearly expressed in the dream (doubt) : $(a)$ through his worry whether he is at the right station; (b) through his hesitation whether he ought to spend

- Ten also refers to the hands and signifies masturbation. In popular jargon the penis is actually called the "eleventh finger." As this dream belongs to a member of the clergy, ten here has an additional significance: the ten commandments. In connection with the great significance of religion in the determination of the neurotic symptoms, the figure 10, among the numbers, is always important. 
that coin; and, $(c)$ through the typical expression: "I did not know what to do."

This dream already informs us that the subject is unable to give up his masturbation habit and to assume regular intercourse with women: that is the foundation of his psychic conflict. The path towards woman is blocked for him also through his incestuous leanings which cause him to lean to the opposite direction,-towards man. The missed train has the same meaning here as in the dreams previously analyzed. He will never reach his sister. Hand-grip refers to the sexual meaning of "baggage" ${ }^{6}$ for genitalia. He has "too much baggage." He is burdened too heavily with sexual cravings. He reverts to masturbation. He overcomes his scruples.

Masturbation (hang-grip division) replaces incest. That is the reason why he avoids women. The practice of masturbation being linked with incestuous thoughts is for him more pleasurable than any other erotic experience.

It should be very edifying to turn now to a dream in which the affects are covered up (or distorted).

- The male genitalia are called popularly das Päckchen, das Gemächte, das Gepäck (the baggage) and finally, also, das Gewicht,-weight or burden: Anthropophyteia, vol. II. In the same way, Koffer, Ranzen, Korb, Kiste, Sack, Rücksack, Tasche and Handtasche are vulgarisms for the female genitalia. The expression "baggage," used in a sexual sense, is mostly a scornful term. 
Sometimes things which the dreamer understands perfectly well in the dream appear mere nonsense in the waking state. Here we have the opposite of that: a dream in which something apparently baffles the dreamer:

(92) I read of a complaint by Mr. X. against Weihrich, the high-school principal, who passed aroay that very day. There were three counts in the indictment and Weihrich was found guilty only on the third count which accused him of walking in sandals and of something else. I could not understand that.

Later: I saw a photo of Gessmann and spoke with him about it.

The evening before the dream Beta ate dark buttered rolls, called in Vienna Bosniak, or Hadschiloja, after the name of a Bosnian insurgent leader. Shortly thereafter he vomited and felt pain in the kidney region. He thought it was due to acids. All acids cause him to vomit. He has similar pains. followed by diarrhea if he eats soft pears.

The analysis discloses important associations to school principal Weihrich. First the associations: Weihrich,-Weihe,-Weiher,-Wei (woe). Association with $\mathrm{X}$ (-feet) Wei-and Gessmann,-the well-known antisemite,-scorn against his physician. His plaint is that the latter has robbed him of the enjoyment-value of his perversions. He feels as 
if plunged into a dizzy, cloudy state (smoke). Dizziness leads to rocking. He recalls that as a small boy he was once rocked on the knee by a soldier.

That is the root of his foot fetichism. Toe-sucking is a part of this condition, as has been pointed out by Adler.

The subject yearns to take into his mouth a dirty, sweaty foot,-especially the great toe. The symbolic equation displaces foot for hand, the great toe for the thumb which in its turn stands for penis or nipple. This leads to perversion (fellatio) and the nurse complex.

Bosniak is a Viennese colloquialism for a Bosnian soldier. Hadschi-loja leads him to hatschen=tramping. His vomiting, pains and the diarrhea lead back to an old phantasy, -sticking. the toe into the mouth and swallowing the perspiration (butylic acid = butter). Waking phantasies just before falling asleep: swallowing a big foot.

Another determination of the foot fetichism: he has been taught to regard the penis as something disgusting, something to be ashamed of. He transposed all the libido to the erogenously endowed foot.

Gessmann leads back to the English term "guess." I am the one who is merely guessing,who knows nothing. The photo (my picture) looked to be a very poor one. It was altogether too light. Gessmann is dark. White,-reeiss-again leads him to Schreeiss, - sweat-and to his idiosyn- 
crasy against juicy roast beef. In the hunter's jargon blood means sweat. Roast beef also reminds him of perspiration,-avoidable by the wearing of sandals. (Symbolic equation: blood, sweat, pus, saliva, spermatic fluid, air, language, money, etc.).

There are three features in the dream: $(a)$ his English woman, (b) his brother, (c) foot perspiration. From the first two I have already weaned him through the analysis; now I am about to take him away from the last. Hence the scornful attitude,hence the reproach: foot,-flat feet,-Weigeschrien (outcry). Further associations lead tó Eugene Sue's Wandering Jew, and this again to suer, Fr., perspiration.

But he himself is the Ahasverus. One of his favorite phantasies was the story of Ahasverus, of the Flying Dutchman, or of some other wandering hero. His phantasies about foot are masochistic, revolving around the idea of expiation.

What he "cannot" understand is what he learns through psychoanalysis. The moment he understands it his compulsive neurosis is over. But the infantile compulsions secure for him much pleasure. $\mathrm{He}$ does not want to give them up.

The dream contains a number of deep affects. It discloses great scorn of the analyst. But all this is so covered up that the dream apparently is void of affect.

Finally, I am dead. He relegates me to the ranks 
of the deceased. Walking in sandals means joining eternity. Sometimes he does not understand me. Er ist ihm etwas zu geistreich. I have also become a ghost (Gesstmann = Geistmann). A ghost is white, pale. I have too much color to suit him. But I exist for him only in a picture (photo). That opens a new path of associations: his belief in the reality of the devil. I am the devil for him. I am rendering him potent, i.e., connecting him with woman. $\mathrm{He}$ wants to remain an ascete, - a holy man. He is continually dwelling on situations in which he is dealt with unfairly. He is invited to an evening entertainment. The thing is called off. Immediately he builds up a serious offence out of it. He is looking for irrelevant troubles. He likes to think of himself as suffering unjustly. After the evening entertainment was called off he wrote me the following interesting letter:

"The cancellation of the entertainment which was due to-morrow, that change followed closely by another change of plans, has caused me considerable depression, although I find the postponement of the hunting trip, on the whole, rather pleasing, for hunting always makes me nervous. Indeed, even the depression was not without its pleasurable feeling. The disappointment, the setback, brought me a certain measure of satisfaction. I am masochistic. And the masochist is passive. Woman is passive, man is active. That is the reason why the masochist has the feelings of a woman, and wants a man 
to dominate over him; he seeks an active person; hence the preference for a soldier, - an active soldier. The chief passive pleasure, the chief gratification of the masochist is the 'pati,' the 'passion, hence the ideas of expiation; his worst Unlust, action, i.e., coitus.

"As a child I must have been the victim of some great injustice which, nevertheless, gave me pleasure, and now I am evidently always trying to reproduce the situation.

"And, in fact, have I not renounced everything worth while? My illness is an expression of complete self denial. Ich koitiere nicht,-I live asexually, I hardly meet a companion, I do not go to the theater, I shut myself up more and more away from everybody, engrossed in my books. My feeling of dread protects me against gratification. I even have moments when I wish nothing better than to die off and be wholly forgotten: the highest masochism."

During these deep impressions he has a very remarkable day dream phantasy:

(93) There roas a man who was sentenced on a false charge of murder. The strange thing was that he hardly defended himself and he heard the sentence with the calm of one who, if not guilty; must be an angel. $\mathrm{He}$ is sentenced for life. His behavior in gaol is so wonderful that even the gaol guards look upon him as a holy man, he consoles those who are ill, heals them, he almost works wonders. After years and years the story of the man's holy character reaches the gaol commissioner who 
pardons him, but without lifting the sentence. The neres is brought to the man. But the saintly man has lost all contact with life, and all sense of its pettiness. $\mathrm{He}$ is transfigured,-he is Christ himself; his greatest triumph is that he has lost his sexuality through saintliness; he is sexless and like an infinite ray of light draroing heavenrerards. The commissioner is speechless, - unable to approach him at all; he continues his existence in his own way.

This phantasy discloses the roots of his asceticism. He complains that he is leading a sinful life (Weihr-ich).

The term Weihrich is very ingeniously chosen by the unconscious. It refers to his devil- and smellcomplex. (The devil stinks.) But, as Weihrauch, it also leads to the holiness-complex. The commissioner (or director) stands for the father. The latter has once punished him unjustly. This is the infantile situation which he reproduces in later life: "Blessed are they who are persecuted for righteousness' sake. For theirs is the kingdom of heaven."

$\mathrm{He}$ is longing for the kingdom of heaven. He wants to reach his father. Through his asceticism he means to earn for himself a higher place in heaven. At this point we find that Adler's conception is corroborated. He wants to be a woman,to possess no penis. But these female trends merely serve the purpose of enabling him to triumph over 
the father. He wants to join eternal life and therein triumph over his father. He, a holy man, his father a sinner. He wants to raise his voice against his father (director) before the divine stool.

But what is the reason for his antagonism towards the father? It is the old rivalry,-over his English governess. The latter was his greatest love. After the nurse, the governess was the dearest person to him. She could not be friendly with any one else. That made him mad. His father was rather more than warm in his attitude towards the English governess. Beta has had opportunity to observe and listen to a number of things, small and big, which made his blood boil. How could that be? His Mary kissing some one else? It hurt his feelings; it roused in him bitter thoughts and fancies of revenge. A little child is helpless against the adults. But with some poison he might easily revenge himself on his enemies. Hence the nausea and vomiting and the diarrhea after eating $\mathrm{Hadschi-}$ loja. The father was a Pasha,- - he owned a harem. His masochistic thoughts are compensations for the criminal tendencies of his childhood.

Furthermore, I am the director against whom he complains. Chiefly on account of the third point (or count) : III point-III illness-III = third sex -homosexuality. His hatred is unrequited love. Who would have suspected this array of affects back of that dream? 
The next dream is also rich in affective coloring and belongs to a compulsion neurotic, Mr. Gino:

(94) A steamboat arrives in our harbor; I want to dodge to the right, but cannot. I go to the left, on a country road. Many people run around scared, shouting: something terrible is happening! I feel the same roay. I am in uniform and I come upon a little boy who presses a big dagger in my hand. Terrified I shout: "away with you, dream ghost." And he promptly disappears.

The little fellow's name is Teller. The affect of the dream is expressed by the many people running around and shouting: "Something terrible is - happening!" We know that "many people" means a secret. He has the same feeling! The horrible thing that is about to happen, is-a murder; he is given a dagger by the boy. During his early childhood he had overheard coitus between his parents (Entry of the steamer into port); he wanted to fly away from this memory, namely to the right, but, instead, he drifted to the left. He wears his uniform; it reminds him of his military service when he had severe crises of illness and so that he was finally discharged on account of neurasthenia.

- Wearing the uniform in the dream means being naked, for nudity is the only uniform which makes all men equal-uniform. Clean underwear is also represented in the dream as a speckled uniform. During his military service period he also had the 
compulsive thought of knifing some one. The great burden of his compulsion was the murder of his brother or of his father. .A painful thought, therefore in the dream it is portrayed as a dream ghost.

"Away with you, dream ghost!" 'means he does not at all entertain the thought,-it was only a dream,-a dream occurrence which we have considered already in connection with some illustrations.

The little fellow, whose name was Teller, he at first identifies as Amor, later as representing the penis, das Heinzelmännchen, der Däumling and finally as the Schneiderlein. Teller first recalls to his mind the act of cutting meat on a plate (Teller= plate); also a maid-servant who broke a plate; also Tiller, a manufacturer of uniforms where he had secured his uniform; also to tell (English): Tuttel, female breasts; further, tailor (English); and that leads him to an English fairy story about some clever little tailors who bound down a giant with their tapes. He had already thought of Wilhelm Tell, the slayer of Gessler. Tell is linked also with Johann Parricida. Since the terrible deed that he was about to commit was nothing less than murder the dream affect appears thoroughly justified. The dream also discloses the influence of a castration fear. He had been threatened with castration on account of masturbation. $\mathrm{He}$ wants to retaliate with bloody revenge.

$\mathrm{He}$ is a man continually harboring murderous 
thoughts against his people. Always unconsciously, of course. Every electric car, every local train, every horse is a possible death messenger. The steamer may run down a little boat. Once his father and his brothers nearly encountered just such an accident. One may meet robbers on the country road. Bicycle, automobile, street, stormy weather, poison, infection-all these served his murderous ideas. But his wish has turned into anxiety: he fears he might hurt others-injure them-perhaps infect his hands and thus spread poison.

Formerly he entertained thoughts of murder. He thought of attacking his mother and of knifing her. Out of revenge. Because she turned her love to a girl child. Through yearning. Because such a murder represents symbolically the expression of violent possession. He expiates for these murder instincts with his neurotic tortures. He finds himself in the attitude of a murderer grasping a knife and he does not want to contemplate the picture.

Freud has repeatedly emphasized the identity of the dream thoughts with the various neurotic compulsions. I want to give one additional example. A patient, while at a health resort with his brother had the feeling: "I cannot stand it any longer. I shall jump at him and knock him down!" The analysis disclosed the vestiges of a powerful infantile attachment to that brother. The feeling: "I cannot stand it any longer, I shall jump at him, knock him 
down und per annum benutzen," is "here turned into anger. Fear (of self) is often turned into anger. This conversion is particularly clear in the infantile form of anxiety neurosis. Children who fly easily into a temper, are victims of an excessive fear. $^{7}$

Another example.

A medical student fails at an examination and acquires a great hatred against his examiner, Professor Zuckerkandl. Among the various ways in which his wild fancies conceive revenge is the following: he is intimate with the man, that is, on equal footing, and asks him that er ihm durchkommen lasse. He also harbors the fancy that the professor is under obligation to "him for some service. He need only remind the man of his debt of gratitude. This patient, Zenta, has the following dream:

(95) I find that Prof. Z., whom I consider responsible for my misfortune, is really a close acquaintance of mine. I meet him and he treats me in a very friendly and obliging manner. I am certain that $Z$. is bound to me by certain moral obligations. I try to give him to understand in an indirect way that since we are such close acquaintances and in view of the fact that he is under obligation

1 "Here we note the biologic root of the fourth symbolic equation: "Any affect may replace any other affect in the dream." Fear, anger, fury and doubt may substitute and vicariously replace one another. The agoraphobiacs lose their fear of open places while angry. 
to me, his conduct ought to be more pleasing. I did not disclose that he had behaved very hinterlistig-tricky-towards me. But he showed me further reaction whereas I spoke to him as I would to a person holding a great social position (Cabinet officer, or something). On account of his high social position I have avoided in my conversation with him all references to his duty and my Durchfall -examination failure. The dream ioas strongly emotional.

At once we recognize that this person of high social standing is none but the father with whom his relations are very cordial. He is very courteous in his attitude towards his father but at the same time regards him as the original cause of his neurotic trouble. The father is obviously anal erotic and has preoccupied himself to a suspicious extent with his son's anal functions.

In the dream he finds that the examiner to whom he ascribes his misfortune (misfortune at trial with woman, for he is impotent with woman and a masturbator, i.e., misfortune with reference to the true test) is really a close acquaintance. An acquaintance who has once bribed him with sweets and to whom he owes all sorts of early erotic pleasures. "He treats me zuvorkommender Weise"; that is literally true. He has a vague notion that it is his father's moral duty to take care of him, for is not the father responsible for his misfortune? The 
dream discloses the wish to tell his father so,-at least in some indirect way. He expects a kulanteres behavior,-ein kulanteres Benehmen. The associations are: cul,-popo, with which is also associated the term "hinterlistig" (cunning) in the sense of some one lusting (lusternd) for the posterior parts. The high social position refers to the father, while Durchfall (failure, but literally, a "falling or passing through") links anal functions to the result of the examination. The situation: "treating very gently some one who is actually being hated" breaks forth very plainly and it contains the roots of the neurosis; the latter is centered chiefly on urolagnia and coprolagnia.

Mr. Gino, a compulsion neurotic who dreads unfaithfulness, treason and dirt, and who is burdened with a compensatory washing mania, dreams:

(96) I am going to a prostitute; first I visit Frau Strabo and her sister. I see that her nose and fingers are rorapped up in white bandages. At parting I offer her my hand but I think to myself I cannot go to a prostitute for I have to go home first and wash my hands and there is no time for all that to-day. The fact is I am afraid of spreading some infection if I should not first wash my hands.

This subject has had dream No. 94. His fear of contact is grounded on altruistic motives: he is not afraid to catch the infection himself, his fear is that he will carry and spread to others the diseased 
germs. This fear is expressed plainly in the dream. We note that the fear is roused through the fact that he had shaken hands with a woman, Frau Strabo, whose hand was bandaged. Strabo suggests to this subject-he is a physician-strabismus and he talks about that. He himself once had a squint,-internal. In this connection I may mention that a number of disturbances of vision are due to self-imposed punishment for seeing what is forbidden. The patient carries out upon himself the lex talionis. This lex talionis is illustrated in the belief that looking into the mirror precisely at the midnight hour brings on blindness and in the belief of pious Jews that it is not permissible to look at the Kohanim, or priests, while they offer the benediction. I recall an ocular trouble in a boy, eight years of age, which the attending oculists were unable to explain and which was due to the fact that the boy had witnessed something he should not have seen. ${ }^{8}$

This patient's squinting was also a neurotic symptom: he has "squinted" too eagerly at his mother's and his sister's charms. ${ }^{9}$ His mother took

- One of my patients relates that his mother once called out to him while she was urinating: "don't look this way or you will be blinded!"

- Cf. Freud: Die psychogene Sehstörung in psychoanalytischer Auffassung, Aerztliche Standeszeitung, 1910, No. 9. Freud expresses the punishing power of the conscience as follows: "Because you wanted to misuse your sight for evil sensuality, it serves you right not to be able to see at all"" 
care of him after he underwent a nasal operation and her tremendous self-sacrifice made an unforgettable impression on him. But ten years later he also had an operation on his penis, requiring considerable after-care. The wound did not heal readily and this twenty-year-old boy was bandaged daily by his mother. The touch of her delicate hands roused very pleasurable sensations.

In his Familienroman the phantasy of the mother as Dirne played a great rôle. Also in his masturbation phantasies. On account of the latter habit he considered himself unclean and the whole washing mania was traceable back to his masturbation habit. As Freud has very fittingly pointed out the manias refer not to the habit itself but they pertain to the accompanying phantasies. In this case the phantasies were of such a character that the mother darin zur Dirne gemacht rourde. . . .

In the dream, before going to the prostitute he visits Frau Strabo; that is the manner in which the dream expresses the thought phantasy that he is calling on Frau Strabo and that the latter is a prostitute: Strabo he identifies with a prostitute. Offering her the hand at parting is a reminder of the contact of his mother's hand with his penis and here the fingers are the symbol of the penis. Also of the thought that, if he be impotent, he will carry on digital manipulations. Thus the prostitute becomes unnecessary. Naturally his reason in the 
dream "he must go home to wash his hands," is a bit of dream distortion which, when read inversely, means: "this phantasy has made me so unclean that I ought to go home and wash my hands!" "No more time for all that" refers to the fact that on the night of the dream his mother was not there; she had just started for home the previous evening, after a visit of several days.

The fear he might spread some infection is obvious; infection through prostitute or mother; nose reminds him of a destructive luetic lesion of the part; fingers, of psoriasis palmarum. But Freud has taught us that, whenever present, these fears are decidedly justified on the part of our patients. In the dream too, the affect stands out as the real valid feature. Everything that centers around the affect may be changed, transposed, distorted. But the affect retains its justification even under transformation.

And here we discover that this subject, indeed, has particular reason to fear the danger from which he would protect others. The fact is he harbors the thought of poisoning his father and brothers,-a phantasy which has played a tremendous rôle in his youth; also the notion of knocking them down. He feels constrained to wash continually because, like Lady Macbeth, he wants to remove the blood stain off his hands. And reduced to its elementary form the anxiety state means: "I fear that my 
criminal passion for mother might induce me to injure father and the other members of the family. I fear this especially as I have repeatedly wished them dead!" Just as his washing mania is a protection against the moral contamination to which he felt himself exposed and at the same time symbolizes his cleansing off his hands the blood of the victims, so he carries out other remarkable compulsive acts which indicate very plainly that these Abrehrhandlungen are compromises between withholding and yielding. He sticks the right index finger into the hollow of his left hand, carrying out a rotary motion and he rotates his hand in a peculiar fashion in the water. Moreover he has: or rather has had,--for he is now cured,-a most peculiar washing ceremonial, - a strict ritual he had devised and this too was cleared away through the psychoanalysis after it was reduced to its wish connotations. ${ }^{10}$

A minor example for a conclusion. A dream of Sigma (vid. Dreams Nos. 70, 71, 72, 73, 82, 83). (97) I am standing in an open place. I am forced

${ }^{10}$ Poisoning has a deeper determination in the significance of poison as spermatic fluid and of poisoning as pregnancy. (Extension of the second symbolic equation.) One of my patients was afraid that his sister would become pregnant through the water in the bath tub, because he masturbated while bathing. Gino had the same fear. The widespread fear of syphilis is largely motivated in the same way. Poison stands also for money; money for penis: vid. Anthropophyteia, vol. VI, p. 15. Thus we uncover here a new determination for the anal-erotic avarice. 
out or else compelled to keep my place (?). At any rate I am under some compulsion, but I do not mind it.

Analysis: The dreamer has proposed marriage to a certain girl, a step he has since often regretted. A short time afterwards he wrote her a letter breaking up the engagement. She was on the point of committing suicide. He became engaged a second time. Shortly after this second engagement his severe neurosis broke out. All that is expressed in the short dream. The open space is his bride; but "freier Platz" is also satire. Any one else was welcome to his bride. He took up a "free spot" (literal meaning of the term).

$\mathrm{He}$ is forced out. That is literally true. His sister compelled him to give up the engagement. In fact she dictated the letter in which he apprised the girl of his change of mind. "Or perhaps compelled to keep my place." Also true. His bride now holds on fast to him and would not let him free. His psychic conflict formulates itself as follows: should he keep his word and marry a poor girl, or become free and break his word to be so. It shows also a competitive struggle between two women for his love: sister and bride. What is his wish? He is not self-reliant. He wants to be led to a decision. That is the reason why he is apparently so unconcerned. But his "not minding it" is the greatest hypocrisy. It should be: "I am im- 
mensely worried over this uncertainty!" The feigned affect of indifference is a pure wish fulfillment. How clearly his doubt is expressed! "Forced out" or "kept down" and with a question mark.

Any one who has read the previous dream analysis pertaining to this case will see at once that this apparent indifference is a cover for affects so tremendous that they have actually led the subject to the brink of committing suicide. This illustrates the true character of dreams apparently free of affects. The absence of affectivity in this case represents a wish fulfillment in the midst of tremendous affects.

Often the dreamer wonders about some occurrence in the dream. Let us analyze a dream of this type:

(98) In Weihburg street I saw Mr. Springer sitting on the Kutschbock,-coach-box-of a carriage in conversation with three Hungarian infantrymen. One had a dark mustache; the two others had only little blond beards. I wondered about Mr. Springer's conduct. It seemed vulgar and degrading.

This Herr Springer represents his father. He reproaches his father with his own adventures. (Springen,-bespringen,-begatten.) The carriage is the Englishwoman with whom the father was intimate. But who are the three infantrymen? The dreamer's associations lead to the male genitalia, - the sexual trinity. The big one with the heavy 
mustache is the penis, the other two symbolize the testicles. His father had given too much thought to his genitalia.

That is the true theme of his surprise. But another infantilistic reminiscence occurs to him. The Hungarian soldiers with their narrow trousers reminds him that he has once played with dolls. He examined anatomically each doll and was surprised to find no genitalia. Only smooth limbs. No opening anywhere. Next, he tore apart the dolls' bodies. He only found sawdust within.

He came to the conclusion that dolls and women had no "pipi." That surprised him very much. He saw a ballet dancer once, Abel, in a flesh-colored tights and he called out: "Abel has no "pipi.", For years afterwards he remembered and repeated that incident.

The greatest degradation to him was to have no "pipi." He indulged in revenge fancies in which he pictured himself as tearing off his father's genitals. Why? Because his father had threatened him with castration to cure him of handling his prirate parts as a child. He was also tremendously attached to the Englishwoman. Hence his boundless jealousy. He wanted to revenge himself by castrating his father.

The result of these experiences and fancies was a psychic impotence of which he was cured only through the analysis. 
Wundern (wondering) leads here also to wound, -Wunde, - the result of castration, and to trauma, a theme which we have already dealt with previously.

Observe the similarity of Weihburg street and Weihrich (Dream No. 92). The affect of wondering, too, is spurious. (Symbolic equation of affects.) It stands here for anger and means: "I am terribly worried over Mr. Springer's conduct."

The apparent lack of affectivity in a dream is always an interesting problem. Many dreams of most horrible content seem emotionally colorless. Why is that?

A gruesome dream of Freud's finds an easy interpretation which explains satisfactorily the absence of affectivity.

"The dream about the old bridge" says Freud, "which confronts me with the task of sectioning my own pelvis is characterized by the absence of the awe proper to the situation. That is a wish fulfillment in more than one sense. The sectioning represents the self analysis which I carry out with the publication of my book on the Interpretation of Dreams, - a task so unpleasant that I have delayed for over a year the printing of the finished manuscript. The wish is that I lift myself above this handicapping feeling,- - that is why $I$ experience no awe in the dream. In another sense, too, I wish to overcome my feeling of aversion,-to avoid Grauen (Literal sense: turning gray); my hair is turning 
gray and that also reminds me that I must delay no longer. We know that towards the end the thought breaks forth in the dream, that if $I$ pursue a vacillating policy towards my aim I may have to leave the task to the new generation." (The Interpretation of Dreams, Translated by A. Brill, Macmillan Company, New York.)

The absence of affectivity in this dream of the founder of the new science of dream interpretation is also a wish fulfillment. It shows Freud's wish to overcome the "inhibiting emotions."

Thus even the emotionally colorless dreams corroborate the principle which I am propounding: There is no dream without powerful affects. The power of dreams to penetrate consciousness depends on the strength of the dream-building affects as well as on the depth of the slumber. ${ }^{11}$

${ }^{11} P$. Meunier and $R$. Masselon, Les rêves ot leur interprotation (Blend et Cie., Paris, 1910) arrive at the same conclusion: "La logique des rêves est entierement affective." 


\section{INDEX OF SUBJECTS}

Affect, 262, 281,283 passim, $295,308,311,313,314$

Aggression, 109, 165, 179

Anal eroticism, 217, 220, 257, 304, 309

Anger, 303

Antagonism, 299

Anthropophyteia, 48, 88, 148, 181, 182, 184, 191, 199, 292, 306

Antithesis, 115

Anxiety, 36, 89, 100, 103, 154, 202, 221, 222

Apoplexy (fear of), 263

Art, 26

Asceticism, 24, 258, 298

Associations, 55, 96, 101, 103, $120,163,188,205,224,231$, $240,243,257,276,293,294$, 296,301

Authority, 23

Belief (in dreams), 17

Bible, 29, 30, 93

Bipolarity, 96, 115, 282

Birth, 97, 98 passim, 107, 117, 208

phantasy, 87, 219

Bisexuality, 66, 79, 103, 149, $166,179,184,195,196$ passim, 198, 199, 204, 233

Cannibalistic trend, 277

Castration, 143, 196, 220, 312

Censorship, 170

Character traits, 201

Circumcision, 79

Coercion, 89
Coitus interruptus, 101

Colloquialism, 35

Complex, 132, 220

Compromise, 201

Compulsion, 222, 225, 284, 301, 302

Concepts, 115

Condensation, 123, 135, 143

Conflict, 169 passim, 239, 272, 292

Conscience, 18, 24, 163, 169, 243

Consciousness, 18

Consolation, 44

dream, 75

Contrary meaning, 112, 113 passim

Craving, 13, 21

Criminality, 179, 184, 290, 302

Culture, 18, 21

Death, 24, 80, 97, 98 passim, $102,103,107,110,135,170$, $179,219,251,296$

phantasy, 100

wish, 254

Defence, 109, 198

Defloration, 83

Demons, 15

Devil symbolism, 201

Disappointment, 117

Displacement, 139, 140, 144, 150,152 passim, 155, 161, 166, 264, 272

Distortion, 82, 93, 97, 107, 109, $150,161,170,175,308$

Divinity, 200 
Dizziness, 214, 260, 294

Don Juan, 117, 133, 210

Doubt, 115, 188, 245, 272 passim, 291 compulsive, 272

Dramatization, 21, 34

Dream thoughts, 126, 165 work, 57

Dress symbolism, 198 passim

Emasculation, 196

Emotions, inhibiting, 314

Envy, 260

Erectio, 79

Eroticism, 89

Excitation, sexual, 40

Expatiation, 296, 302

Even and uneven, 223

Fairy story, 43

Faust, 18, 19, 21

Fear, 89, 100, 110, 151, 162, $167,177,222,306,308$

Fellatio, 143, 145, 151, 217

Fetichism, 220, 294

Flesh symbolism, 32

Fixation, emotional, 217, 219, 231

Flagellation, 223

Function (of dream), 19

Fusion, 65, 161, 164, 170, 220, 225

of time, 87

Future, 24

Grandeur, 40

Gratification, sexual, 209

Guilt, feeling of, 177

Habitus, 201

Hallucination, 18

Hatred, 282, 299

of father, 215, 283

Hermaphroditism, psychic, 81, $136,143,15$ I, 156, 187, 195, $198,200,201,206,209,262$
Homosexuality, 109, 155, 166, $170,208,219,221,261,266$ Hysteria, 156

Ideal, 25, 117

Identification, 175, 191

Impatience, 33

Impotence, 34, 258, 259, 312

Incest phantasies, 151, 191, 193, 194, 208, 216, 230, 232, $245,261,263,291,292$

Inciters, dream, 164, 271

Indecision, 241

Indulgence, 23

Infantile root, $74,125,131$, $144,170,215,217,271,302$, 312

Inferiority, 135, 201

Inhibition, 18, 21, 103

Instinct, 17, 109

Interpretation, 31

Inversion, 178

Itching, 220

Jealousy, 103, 274, 318

Jesus, 17

Job, 17

Joseph's dreams, 30

Language, 19

Latent dream thought, 56,93 , 195

Law of opposites, 109

Left-handedness, 214, 221, 293 passim

Lesbian trend, 202, 204

Lex talionis, 306

Libido, 200

Lingam, 112

Linguistics, 110

Love, 207, 209

Male "protest," 195, 197, 207, Manifest dream content, 66 , 93

Masturbation, 103, 151, 156, 191, 192, 215, 265, 292, 307 
Maternal body phantasies, 83, 103

Meaning (of dreams), 56, 93, $100,108,125$

Misophilia, 74

Mistrust, 165, 245

Morality, 180

Murder phantasy, 290

Myth, 46 passim

Narcissism, 66

Necrophilia, 184

Negation, 97, 253

Neuralgia, 180

trigeminal, 204,

Neurasthenia, 238

Neurosis, 23, 170

Nonsense (in dreams), 293 passim

Nose boring, 140

Nurse complex, 294

Opposites (law of), 109

Overdetermination, 74, 97, 257

Parallel, symbolic, 139

Parsifal, 17

Periodicity, 95

Personality (splitting of), 175, 176 passim, 180 passim

Perversion, 89, 296

Phantasies, homosexual, 258

Phantasy dream, 67

Pleasure, 18

Poetry, 58

Pollution dreams, 224

Potence, 40

Psychoanalysis, 201

Reality of dream, 16

Religion, 46, 203

Reminiscence, early, 245

Repression, 17, 183

Resistance, 56, 202, 267

Responsibility, 90
Revenge, 146, 220, 302

Right-sidedness, 222 passim

Sadism, 277

Scorn, 166, 239

Self-control, 23

reproach, 102

Selfishness of dreams, 175

Shame, 145

Soul, 147

Splitting of personality, 169

Squint, neurotic, 306

Stereotypic dreams, 223

Substitution, 282

Suicide (thoughts of), 171, 174

Surprise, 311

Symbol, 28, 45

bisexuality of sexual, 197

Symbolism, 19, 26 passim, 34, $36,39,45,93,107,167,225$

Tension, sexual, 41

Test dream, 222

Time, 23

Transference, 47, 146, 150, 155, 189

Transposition, 74, 116, 139, $145,149,194$

from below, 109

Trend, criminal, 49

Twilight state, 49

Unconscious, 48, 4958

thought, 125

Unpleasure, 18

Vertigo, neurotic, 214

Virginity, 183

Vomiting, symptomatic, 294

Waking, 24

Warning, 24

Washing ceremonial, neurotic, 309 
Watchful persons, 163

Water dreams, 117

Will to sleep, 20

Wish fuffillment, 19, 21, 23, Wonder, 311
$24,32,75,81,85,89,133$, $202,209,228,287,311$ Wit, 49

\section{INDEX OF NAMES}

Abel, 113

Abraham, 47, 216

Adler, 81, 109, 156, 166, 195, 201, 204, 206, 214, 294, 298

Aigremont, 67, 214

Artemidoros (of Daldos), 30, 31, 93, 152

Baeder, F., 112

Baumbach, 61

Bechstein, 44

Bethe, 147

Binet-Sanglé, 36

Bleuler, 281

Brill, A., 57, 222, 283, 314

Buadem, 33

Burger, 213

Cardanus, 33

Celsius, 252

Eulenspiegel, 33

Euripides, 254

Feuchtersleben, 26, 160, 280

France, A., 17

Freud, S., 19, 26, 35, 36, 40, $43,49,50,57,74,97,107$, $113,115,123,152,161,175$, 196, 202, 222, 239, 271, 272, $283,302,306,308,313$

Fliess, 196, 214, 221

Ganghofer, 95

Goethe, 162, 212

Grillparzer, 25

Grimm, 45

Gross, 0., 50
Hebbel, 20, 26, 48, 55, 183, 207, 270

Heyse, P., 192

Hirschfeld, M., 198

Hitschmann, 50

Inmann, Th., 87

Jones, E., 38

Kleinpaul, R., 27, 37, 108, 240

Krauss, F. S., 30, 48

Kürnburger, 14

Lessing, 129

Lichtenberg, 174, 186

Marcus Aurelius, 72

Masselon, R., 314

Maupassant, 250

Meissner, 134

Meunier, P., 314

Müllendorf, 33

Nassr-ed-din, 33

Nietzsche, 15, 138, 183

Rank, O., 48

Riklin, F., 27, 43, 44, 45

Ritterhaus, 45

Rückert, 263

Sadger, 196

Scherner, K. A., 40, 100

Schiller, 263

Schnitzler, A., 251

Schubert, 37, 98, 110

Shakespeare, 183 
Stekel, 239, 284

Sudermann, 125, 128

Swedenborg, 111

Swoboda, 95, 196, 236, 252
Van Teslaar, 25, 30, 58, 239

Wagner, 106

Weininger, O., 196

\section{INDEX OF SYMBOLS}

Acorn, 112

Actress, 66

Air, 132

Apron, 193

Assault, 108

Assembly House, 84

Attack, 254

Automatic Eye, 183

Automatic phone, 65

Baggage, 259, 289, 291

Bass, 64

Bicycle, 217

Big Dog, 190

Bird, 187

Baron Rosenfeld, 146

Bismarck, 120

Bite (on Thigh), 205

Birthday, 262

Black Shoe, 80

Blinding Light, 84

Blood, 148, 266, 295

Blouse, 198

Blue Grass, 79

Boat, 204

Boil, 141

Books, 120, 243

Box, 165, 170

Breaking in, 162

Breast, 253

Breast pin, 271

Broad Path, 229

Broken Handle, 79

Brother, 165, 264, 295

Brown, 199

Brush, 4.1

Buelow (Diplomat), 227

Bumpkin, 183
Burgomaster, 84

Burials (many), 264

Bushes, 266

Buttons, 256

Candy, 239

Carriage ties, 88

Carrying, 265

Cat, 187

Cemetery, 203

Certificate, 155

Chamber Pot, 144

Changes (in earth surface), 97

Chest, 165

Chip, 196

Christ, 36

Cigar, 208

Cigarette, 197

Clarinet, 40

Climbing, 156

Closet, 285

Closed Door, 178

Closing Shop, 261

Club, 256

Coffin, 263

Comb, 202

Confectioner, 129

Cover, 256, 165, 256

Court Citation, 246

Cousin, 215

Cross, 180

Crowd, 84, 261, 264, 300

Crown of Thorns, 180

Dagger, 300

Dark Man, 134

Death, 80 
Departure, 257

Dirty Linen, 78

Dog, 76

Don Juan, 38

Dove, 275

Draft, 165

Draft Horse, 88

Drawer, 165, 285

Dying, 252, 266

Eagle, 66

Earth, 97

Eating, 65

Elevation, 224

Embrace, 154

Emperor, 84

Emperor's Colors, 80

Ends, 42

English Woman, 295

Even and Uneven, 223

Evening Meal, 65

Evening Time, 84

Evil Eye, 112

Examination Test, 305

Excrement, 107

Eye, 112, 182

Falling (down or backwards), 260

Falling (into Abyss), 80

Fig Leaf, 42

Fig Tree, 112

Finger, 150, 182, 183

Fire, 169, 175, 220

First (to get in), 162

Fish, 200

Fish Bladder, 183

Flame, 226

Floors, 256

Fluids (bodily), 148

Food, 220

Foot Perspiration, 295

Forced out (?), 310

Forty Degrees, 228

Friend, 80

Friend, Father's, 195
Frog, 200

Fur, 140

Funeral, 261

Funeral Procession, 84

Gate Opening, 84

Ghosts, 261, 296, 300

Globe, 78

Gloves, 285

Gold, 107

Gold Chain, 84

Golden Garments, 84

Grave, 263

Girl, 218

Ground Floor, 256

Growth, 142

Guardians, Three, 84

Hair Dressing, 285

Hall, 208

Hand, 112

Hand Baggage, 292

Hand Grips, 256

Heart, 253

High Official, 304

High Tower, 146

Hoffburg, 120

Hofftheater, 156

Hole, 38

Holy Mother, 204

Indifference, $\mathbf{3 1 0}$

Incident, 120

Inspection, 308

Intruder, 178

Iris, 38

Iron Man, 84

Italian Countess, 228

Italy, 220

Jeweller, 193

Jewels, 285

Jewish Looking, 288

Kneeling, 120 
language, 209

Laundry Bag, 73

Lanterns (Burning), 226

Leaving, 84

Left, 80

Left and Right, 223

Left Side, 226

Left Foot, 210

Life Thread, 88

Little Horses, 208

Little Things, 285

Lodge, 147

Look, peculiar, 215

Man, 218

Man (uncertain size), 129

Meat, 150

Menstruation, 73

Miss "King," 215

Missing train, 291

Money, 64, 229

Monk, 38

Monkey, 35, 278

Moon, 78

Mother, 185, 286

Mouse, 199

Municipal Theatre, 84

Murder, 252

Museum, 182

Nails, 180

Naked, 264

Nakedness, 205

Narcosis, 82

Night Gown vs. Blouse, 197

Nose (eaten away), 263

Numbers, 243, 291

Nun, 38

Office Room, 141

Old Acquaintance, 305

Open Space, 310

Operation (surgical), 82

Outcry, 206

Pain, 206

Palais, 186
Palm, 112

Partition, 170

Peak, 41

Pearls, 240

Pellmann, 132, 135

People's Anthem, 120

Phonix Bird, 112

Physician, 82

Piano, 218

Piano Playing, 113

Pillow Cases, 73

Pipe, 40

Pi-pi, 312

Playing, 113

Pocket, 65

Pocketbook, 291

Poet, 82

Poisoning, 239, 309

Policeman, 162, 169, 170

Preparations, 285

Priests, 261

Prostitute, 195

Pustules, 203

Quadrangle, 96

Quiet Figure, 84

Rat, 199

Receiver (phone), 66

Reception, 84

Recital, 66

Red, 240

Reddish, 275

Red Order Insignia, 84

Red (swollen), Hands, 145

Revolver, 156

Right, 80

Right and Ieft, 210

Right Side, 217

Ring, 78, 79

Road to Temple, 228

Roast Beef, 295

Rolling down, 224

Room, 144

Rope Bridle, 88

Rose, 240

Row, 241 
Ruin, 224

Running Matter, 141

Salome, 183

Searching, 285

Seed, 224

Serpentine Paths, 223

Servant, 186, 170

Setting up, 186

Shaking, 218

Shellfish, 189

Shore, 218

Silent Man, 154

Sinking down, 84

Snail, 199

Snake, 183, 199, 223

Snaky Path, 227

Sofa, 190

Son (the Little One), 146

Son-in-Law, 76

Southern, 219

Spain, 220

Speaking, 148

Spear, 80

Spindle, 38

Spiral, 225

Spoon, 150

Squeezing, 129

Stairway Climbing, 113

Stamp, 38

Standing up, 228

Stars (I.ittle), 240

Strange Child, 150

Strange Man, 190

Strangulation, 150

Struggle, 179

Stumble, 266

Sun, 220

Surprise, 262

Swelling, 142

Table, 239

Tailor, 301

Tears, 44

Technical School, 113

Telephoning, 64

Temple, 229
Ten, 291

Tenor, 64

Thirty-Five, 192

Thread, 78

Three, 298

Throngs of People, 84

Through (done), 286

Toe, 200

Toilette, 285

Tower, 41

Tree, 97, 253

Triangle, 80

Trotting, 218

Trunk, 165

Ugly Woman, 108

Umbrella, 79

Uncontrollable Horses, 220

Underbrush, 41

Understanding, 209

Uniform, 300

Urine, 193

Vine, 112

Vomiting, 148

Wall, 170, 171

Washing Hands, 308

Watchman, 134, 170

Watchman (at Gate), 84

Wax Figures, 184

Weeping, 148

"What are you doing?" 163

Wheel, 79

White, 240

White Apple, 155

Wild Animals, 220

Winter Coat, 145

Word, 112

Writing Desk, 285

Xmas Tree, 208

Yellow Shoe, 80

Yellowish-Brown, 275

Yolk (Egg), 78

Young Boy, 204 




\section{AUG 81986}

\section{please do not Remove}

\section{CARDS OR SLIPS FROM THIS POCKET}

\section{UNIVERSITY OF TORONTO LIBRARY}


